\author{
Universidade de São Paulo \\ Faculdade de Filosofia, Letras e Ciências Humanas \\ Departamento de História
}

Eles não usam blacktie: um estudo sobre Cinema e História

\author{
(Leon Hirszman, 1981)
}

\author{
Dissertação de Mestrado \\ Marcio Hideo dos Santos
}

\author{
Orientação \\ Maurício Cardoso
}

Versão Corrigida

São Paulo

Outubro de 2013 
UNIVERSIDADE DE SÃO PAULO

FACULDADE DE FILOSOFIA, LETRAS E CIÊNCIAS HUMANAS

DEPARTAMENTO DE HISTÓRIA

PROGRAMA DE PÓS-GRADUAÇÃO EM HISTÓRIA SOCIAL

\title{
Eles não usam blacktie: um estudo sobre Cinema e História (Leon Hirszman, 1981)
}

\author{
Marcio Hideo dos Santos \\ Dissertação apresentada ao Programa de \\ Pós-Graduação em História Social do \\ Departamento de História da Faculdade de \\ Filosofia, Letras e Ciências Humanas da \\ Universidade de São Paulo, para a obtenção \\ do título de Mestre em História Social.
}

Orientador: Prof. Dr. Maurício Cardoso

\section{Versão Corrigida}

São Paulo

2014 
UNIVERSIDADE DE SÃO PAULO

FACULDADE DE FILOSOFIA, LETRAS E CIÊNCIAS HUMANAS

DEPARTAMENTO DE HISTÓRIA

PROGRAMA DE PÓS-GRADUAÇÃO EM HISTÓRIA SOCIAL

\title{
Eles não usam blacktie: um estudo sobre Cinema e História (Leon Hirszman, 1981)
}

\author{
Marcio Hideo dos Santos
}

Dissertação apresentada ao Programa de

Pós-Graduação em História Social do Departamento de História da Faculdade de

De Acordo. naunisio Candow
Filosofia, Letras e Ciências Humanas da Universidade de São Paulo, para a obtenção do título de Mestre em História Social.

Orientador: Prof. Dr. Maurício Cardoso

Versão Corrigida

São Paulo

2014 


\section{RESUMO}

O presente trabalho tem por objetivo analisar como as Greves do ABC de 1979 e 1980, foram recuperadas pela atualização da peça teatral Eles não usam blacktie para o formato do melodrama, tomando como pressuposto que essa produção reflete um olhar do contexto sociocultural do período de redemocratização do país e uma crítica sobre o regime militar.

Palavras-chave: melodrama, realismo crítico, cinema, cultura popular. 


\begin{abstract}
This thesis intends to analyse how the ABC strikes of brazilian workers at 1979 and 1980, was represented by cinema about a theatre play called They aren't wore blackties (1955). The present analysis aims to account for both the internal structure of the ficcional narrative and its process of production, considering the specific sociohistorical context.
\end{abstract}

Keywords: melodramatic, critic analysis, cinema, culture. 


\section{SUMÁRIO}

INTRODUÇÃO - pp.1 a 7

CAPÍTULO 1 - ELES NÃO USAM BLACKTIE (1981)

1.1. Propósitos da Pesquisa e Hipóteses - pp. 8 a 15

1.2. O aspecto documental do filme - pp. 16 a 19

CAPÍTULO 2 - PEDAGOGIA DA EMOÇÃO

2.1. Análise do filme - pp. 20 a 48

2.2. Cena dos Feijões - pp. 49 a 65

CAPÍTULO 3 - OTÁVIO E TIÃO ou tensão entre forma e conteúdo

3.1. Maniqueísmo Aparente - pp. 66 a 83

3.2. Estrutura Dramática e Luta de Classes - pp. 84 a 102

CONCLUSÃO - pp. 103 a 118 


\section{Introdução}

Acreditamos que o filme Eles não usam blacktie (1981) de Leon Hirszman representa uma virada na produção nacional do melodrama de escopo comercial, centrado no drama individual do protagonista para uma abordagem do sujeito compreendido como parte de relações sociais capitalistas. A força alegórica do filme está na capacidade de fundir os planos do individual e do social, de modo que não há algo acontecendo às costas dos personagens enquanto eles vivem suas vidas como se fossem dramas individuais. A História e as relações sociais não são apenas pano de fundo por onde "contextualizamos" o drama encenado, mas constituem-se como elementos estruturais que nos permitem uma investigação pelas formas que construíram o conteúdo. Não partimos do conteúdo para definirmos as formas adotadas pelo cineasta para dizer algo importante sobre um momento histórico específico. Procuramos estabelecer desde o princípio uma abordagem da totalidade que pudesse abranger filme e realidade nacional. Eles não usam blacktie constitui uma transição, se considerarmos pelo menos duas perspectivas: em relação à trajetória intelectual do próprio Leon Hirszman como realizador no campo do Cinema Novo e sua inserção no cinema comercial, com aporte financeiro da Embrafilme. E também, do ponto de vista do próprio cinema nacional, com todas as dificuldades de percurso e as possibilidades de maior comunicação com o público, fazendo um cinema propositalmente mais engajado.

Acreditamos que o filme corresponde a uma tomada de posição mais favorável às esquerdas ditas tradicionais, sobretudo, sob a perspectiva do $\mathrm{PCB}$, em detrimento de uma concepção mais entusiasta das greves do $\mathrm{ABC}$. Contudo, não queremos afirmar com isso, que o filme "esculhamba" com greve e o novo sindicalismo. O filme adota 
uma postura crítica em relação ao momento histórico que supostamente apostou demais numa recomposição de forças da esquerda, pela liderança do novo sindicalismo.

Conforme o historiador Marcos Napolitano, havia uma tensão no campo da esquerda sob o regime militar ${ }^{1}$ :

"A nova esquerda é o segmento menos estudado, do ponto de vista da história cultural do regime militar. Objeto de ampla reflexão, quase sempre feita por acadêmicos simpáticos às suas críticas à 'velha' esquerda nacionalista, comunista ou trabalhista, que se debruçaram sobre as práticas basistas e democratizantes dos movimentos sociais surgidos nos anos 1970. Esses movimentos compartilhavam entre si a crítica ao nacionalismo, ao vanguardismo e à aliança de classes, e tiveram importância fundamental no desenvolvimento de uma revisão da cultura política nacional-popular. A criação do Partido dos Trabalhadores em 1980 foi saudada como a expressão organizada desta corrente, aprofundando a crise do frentismo que, até então, era acalentado pela oposição ao regime, sobretudo pelo PCB."

De maneira bem esquemática, do ponto de vista do conteúdo de Eles não usam blacktie poderíamos definir que Otávio é um representante do "frentismo cultural" ligado ao PCB. E que o filme adota a sua perspectiva, que, em última instância, é o ponto de vista de Leon Hirszman. Otávio é a personificação de Leon Hirszman como desenvolveremos na análise do filme.

Sartini seria de uma corrente crítica ao "nacionalismo, vanguardismo e à aliança de classes”, e portanto, poderíamos relaciona-lo ao PT. Bráulio, por sua vez, também deveria figurar numa corrente ligada à "velha" esquerda, mas ele é nitidamente construído como representante da esquerda católica, que foi, segundo Marcos

\footnotetext{
${ }^{1}$ NAPOLITANO, Marcos. Coração civil: arte, resistência e lutas culturais durante o regime militar brasileiro (1964-1980). Tese de livre-docência, São Paulo, 2011.
} 
Napolitano, "uma das matrizes mais importantes da nova esquerda". ${ }^{2}$ O personagem Bráulio também é, ao lado de Otávio, um dos elementos que estruturam a narrativa do filme, como força política coletiva. Bráulio não tem família, nem referência da sua vida privada, ele é inteiramente sindicato, resistência, operariado.

Tião é um personagem mais complicado de definir, configurando talvez uma juventude despolitizada, dentro dos complexos parâmetros do que poderíamos chamar de geração influenciada pelas promessas do "milagre econômico". Tião entende os princípios que animam a militância do pai, compartilha do mesmo sofrimento, mas por outro lado, não compreende aquilo que supostamente Otávio tenta ensinar-lhe, em várias partes do filme, como sendo a verdade sobre a realidade capitalista. ${ }^{3}$

Acrescentaríamos também, Romana e Maria como personificações do participação feminina não apenas como coadjuvantes na greve da fábrica, mas representando a força popular reivindicativa ${ }^{4}$, em consonância com uma ideia de que o cinema e as artes de um modo geral, seriam espaços para recuperar a história do país por meio do imaginário popular, em que as mulheres são agentes históricas ativas. ${ }^{5}$

\footnotetext{
${ }^{2}$ Idem. “(...) Em São Paulo, foram criadas as Comunidades Eclesiais de Base (CEBs) em 1970.

Sua criação significou um importante movimento de confirmação do viés progressista da Igreja Católica, dentro do qual atuava a esquerda, composta por militantes laicos, agentes pastorais e baixo clero. As CEBs foram o laboratório das concepções de democracia comunitária e basista que informaram a utopia política católica à esquerda e os novos movimentos sociais por ela influenciados, cuja emergência histórica, no Brasil, coincidiu com a construção da resistência política e cultural ao regime militar." (p.300)

3 "No capitalismo, é a generalização das trocas que constitui uma forma econômica correspondente, a forma-mercadoria. Tal forma, posteriormente, configura a totalidade das relações sociais - o dinheiro, a mensuração do trabalho, a propriedade e o mais-valor, o sujeito de direito e a própria política. "(p.22) In: MASCARO, Alysson Leandro. Estado e Forma Política, São Paulo, Boitempo, 2013.

${ }^{4}$ Conforme entrevista do cineasta Leon Hirszman: “(...) O cinema nacional-popular é antes de tudo pluralista; nele o artista tem espaço, condições de se manifestar. Não é popular apenas no nível da comunicação, mas também em termos dos interesses que mobiliza, sintonizado com as necessidades do momento. Para nós, na América Latina, o termo popular é inseparável do nacional. Frente às tendências massificantes do cinema e da televisão, que não correspondem às grandes contradições internas e aos interesses dos povos, estes interesses populares, suas limitações, a história popular, têm um caráter nacional." É bom falar, coletânea de entrevistas de Leon Hirszman, p.41.

${ }^{5}$ Idem, p.63. “(...) Minhas reflexões sobre o cinema nacional-popular são antigas, vêm desde o tempo da peça de Guarnieri, passam pelo Cinema Novo, pelo CPC, prosseguem e continuam em Blacktie, tenho esperanças de chegar um dia num equilibrio entre arte e política."
} 
Ou talvez, uma outra definição esquemática para as duas personagens do drama de Leon Hirszman poderia ser, dentro dos pressupostos da história cultural da esquerda no regime militar, a de que elas também poderiam encaixadas numa corrente da "nova esquerda" progressista. A personagem Maria, mais enquadrada nessa definição, precisaria ser compreendida como representante de forças populares progressistas da nova esquerda em harmonia com Romana, personagem que corresponderia à própria forma adotada no filme, formando o contraponto estético pontual entre as duas mulheres, em virtude de sua afetividade pelo marido, militante da "velha esquerda".

As tensões no campo da esquerda durante o regime militar, polarizaram as várias correntes quando as greves do ABC de 1978, 1979 e 1980, irromperam, forçando-as a assumirem suas respectivas posições quanto à "questão operária". Pensando nesta tensão dentro da esquerda, como polarização entre comunistas e católicos percebemos a importância do personagem Bráulio, que na verdade, nem personagem é, configurada no filme, em termos de conteúdo e forma. ${ }^{6}$

A narrativa do filme cria a impressão de inserção do espaço urbano marcado pela violência, do Estado na forma da polícia que mata marginalizados, possíveis desempregados, em decorrência das contradições do "milagre econômico", e portanto, é na forma do filme, que devemos encontrar as tensões que se manifestam na própria relação entre arte e contexto social.

\footnotetext{
${ }^{6}$ Idem. “(...) “A democracia deveria ser construída na experiência comunitária cotidiana; o igualitarismo deveria pautar a relação entre militantes da 'vanguarda' e as pessoas da comunidade; as massas tinham 'personalidade', portanto, não eram passivas no processo histórico. Se o ISEB e o CPC, mesmo realçando o povo como 'ser da nação', ainda se viam como seus intérpretes e formadores, a esquerda católica tentava desenvolver outra ética da militância cultural, valorizando o povo como 'sujeito' e personalizando o ser popular." (p.306)
} 
Vamos acompanhar alguns movimentos construídos pela narrativa de Eles não usam blacktie e como sua força expressiva pode nos conduzir para a compreensão do contexto social está presente no próprio objeto artístico. Nossa proposta fundamental nesta pesquisa é desvendar pela análise fílmica, as possibilidades de estudar a História do Brasil pela linguagem cinematográfica.

Vamos considerar, sobretudo, as sequências finais do filme após a eclosão da greve que resultaram na agressão sofrida por Maria por um agente da repressão e a prisão de Otávio. Em termos de conteúdo, nada a acrescentar, mas quando observamos, os sujeitos dramáticos Romana e Maria confrontando a injustiça social, representada no aparato repressivo que tenta esmagar os operários, podemos relaciona-las com uma força popular, coletiva, que leva-nos a perceber que são personagens em construção numa forma dramática por onde a sua particularidade torna-se veículo de reivindicação coletiva, que permite-nos concluir que assumem a categoria de personagem coletivo no filme.

Não há efetivamente esquerda e direita retratadas no filme, e a "frouxidão" dessas demarcações ideológicas, coloca Eles não usam blacktie como extensão da realidade social brasileira do ponto de vista do cotidiano, e não uma mera estrutura esquemática da luta de classes com uma ordem normativa e os personagens "funcionando" perfeitamente encaixados em seus papéis definidos. Isso se reflete numa "desarrumação" provisória na forma e no conteúdo do filme, comentado subliminarmente em falas de Tião em suas discussões com Maria, onde afirma "Você tá meio maluca aí como todo mundo. O que foi, hein? Tá todo ficando doido, com a cabeça virada!", como se realmente a forma do filme incorporasse aspectos do seu processo de elaboração. Aqui Tião questiona o estatuto de personagem dramática de Maria que age de uma forma inadequada, com a proximidade da greve, assumindo uma 
"politização" incongruente com a sua condição até aquele momento. A possibilidade de mudança, numa perspectiva de processo e personagem em construção, embaralha em certo sentido, a forma e o conteúdo. Por isso, que o próprio ambiente social, ou melhor, o espaço urbano se insere no filme, não apenas como cenário, mantendo uma característica meramente de paisagem. O espaço urbano possui uma densidade de espaço do cidadão, espaço de socialização, espaço político, lugar por onde, diferentemente do espaço rural, dominado pelos latifúndios, o operário pode viver a “questão operária” e a "questão democrática". A rua é o lugar da luta, da manifestação, da greve, do trabalhador revoltado, do desobediente civil, dos metalúrgicos do ABC. O imaginário que o espaço urbano proporciona é tão relevante no drama de Eles não usam blacktie, que consideramos que é por ele que a instância narrativa se sobrepõe como sentido poético mais elevado, acima das contradições ideológicas de Tião e Otávio.

É como se de repente, na discussão entre Tião e Maria, fossemos levados a abstrair do sentido imediato do desentendimento entre eles, e devaneássemos pela "questão operária" e transformássemos a briga do casal numa versão em miniatura da luta de classes. Mas a luta de classes efetivamente foi representada sob uma forma dramática que é questionada permanentemente na tensão que o filme incorporou para valorizar a "revolta popular" na imagem que reverbera com os operários grevistas confrontando a repressão da ditadura militar, com as discussões políticas dos operários, com a solidariedade de suas famílias (Maria e Romana), com a passeata-cortejo reunindo não somente os operários grevistas, mas o "povo" no apoio à continuidade da greve.

Leon Hirszman considerava aqueles 90 dias de filmagens da greve no $\mathrm{ABC}$ como um "laboratório" para o seu longa metragem "Eles não usam black-tie"(1981). ${ }^{7}$

\footnotetext{
${ }^{7}$ SALEM, Helena. Leon Hirszman - O Navegador das Estrelas. Artemídia/ Rocco, Rio de Janeiro, 1997. (p.256)
} 
No filme, a greve é dramatizada, constituindo essa "ebulição" que assinalamos de todos os personagens, como bem percebido por Tião, deixando todos "doidos", de "cabeça virada".

Por isso, a "frouxidão" quanto a um esquema geral mais normativo da ordem social, da definição mais precisa das classes sociais, denotando algo que se reflete na própria forma do filme, como se tudo realmente estivesse em processo. Acreditamos que o filme é solidário ao movimento operário, é um filme com intenção política, é um filme com perspectiva de esquerda, mas não é um filme normativo. Em lugar disso, apostou-se na "espontaneidade" dos movimentos populares, inclusive no tratamento dado ao próprio movimento operário como resultante muito mais da iniciativa do que de uma capacidade confirmada de organização em momentos de crise.

Mas, para finalizarmos, acreditamos ter atingido o propósito desta pesquisa que era investigar a tensão na forma dramática e no conteúdo político (épico) do filme, partindo da "problematização" desta tensão, iniciada por Leon Hirszman e Gianfrancesco Guarnieri que em seus depoimentos afirmaram terem se preocupado com a estrutura da forma da peça teatral e sua atualização para o cinema. E pelo desvendamento do princípio formal da pedagogia da emoção, que é o ganho que o filme apresenta. Se por um lado, há uma perda do ponto de vista do conteúdo, que não conseguiu dramatizar todo o amplo e complexo espectro político e cultural ${ }^{8}$ do período da "abertura política" do regime militar, houve como já dissemos um ganho do ponto de vista da forma. A forma do filme incorpora o movimento proveniente da Greve do $\mathrm{ABC}$, no sentido da imagem produzida pela grande mobilização política e popular, se sobrepondo ao drama de Tião que era o cerne da estrutura dramática da peça teatral.

\footnotetext{
${ }^{8}$ Conferir o trabalho de Marcos Napolitano que utilizamos para embasar nosso argumento historiográfico.
} 
CAPÍTULO 1 - Eles não usam blacktie (1981)

\subsection{Propósitos da pesquisa e Hipóteses}

O ponto de partida deste estudo são os pressupostos teóricos acerca da análise fílmica definida, sobretudo, na obra "Sertão Mar - Glauber Rocha e a estética da fome" de Ismail Xavier. Quando consideramos que "cada filme define um modo particular de organizar a experiência em discurso, sendo um produto de múltiplas determinações", estamos estabelecendo de certa forma que a análise dos filmes é o principal objeto de estudo. Partindo de cuidadosa abordagem do processo de composição dos filmes, selecionamos as perspectivas que possibilitam articular as referências teóricas e metodológicas da História e do Cinema.

Nesse sentido, nossos esforços visam formular interpretações em consonância com os principais temas de estética e política, dentro de uma perspectiva marxista coerente à trajetória intelectual e militante do cineasta Leon Hirszman, que foi um dos grandes realizadores do cinema moderno brasileiro.

Segundo alguns estudiosos do período, podemos afirmar que os anos $1980 \mathrm{em}$ termos de cinema nacional representaram uma fase de esgotamento do modelo estético proposto por muitos realizadores do cinema novo. Na verdade, nunca houve uma homogeneidade tão explícita entre aqueles cineastas. E o que se percebe é que cada um tratou de seguir seus próprios caminhos e trajetos cinematográficos. De qualquer forma, o traço característico da geração de cineastas dos anos 1960 e 1970, foi a preocupação com a originalidade da expressão artística, conjugando estética e política como sentido da função do artista em participar da mudança da realidade social. É o chamado "cinema de autor".

\footnotetext{
${ }^{9}$ XAVIER, Ismail. Sertão Mar, Glauber Rocha e a estética da fome. São Paulo, Cosac\&Naify, 2007.
} 
Um aspecto presente no trabalho cinematográfico de Leon Hirszman é um estilo de narração marcado pelo realismo e pela reflexão da posição do sujeito diante de estruturas sociais que podem conduzi-lo à alienação. Aliás a alienação é tema recorrente em toda a filmografia de Leon Hirszman. Se considerarmos o seu primeiro grande sucesso, aclamado pela crítica, São Bernardo de 1974, adaptação do romance de Graciliano Ramos, Eles não usam blacktie de 1981 e o documentário Imagens do Inconsciente sobre o trabalho da médica Nise da Silveira de 1987, é inegável a temática dos diálogos impossíveis, as posições irreconciliáveis entre os indivíduos. Enfim, uma inquietação com a condição humana "alienada" nas suas várias facetas percorre a obra do cineasta. Como esse elemento presente nas várias temáticas abordadas pelo cineasta se relaciona com a cultura brasileira, com os anseios políticos coletivos, com a estética cinematográfica, com a cultura popular, enfim, com as formas de narração próprias do cinema e como isso tudo pode ter sentido histórico.

Antônio Cândido expõe uma possibilidade de abordagem da literatura, que nos serviu ao propósito de definição teórica que buscamos em nossa análise fílmica. Para o autor, “(...) o externo (no caso, o social) importa, não como causa, nem como significado, mas como elemento que desempenha um certo papel na constituição da estrutura, tornando-se, portanto, interno."10 O autor, ainda, faz referência a Georg Lukács que formulou os seguintes raciocínios: “(...) O elemento histórico-social possui, em si mesmo, significado para a estrutura da obra, e em que medida? Ou seria o elemento sociológico na forma dramática apenas a possibilidade de realização do valor estético (...) mas não determinante dele?” (p.5) ${ }^{11}$ Estudar a influência que o meio social

\footnotetext{
${ }^{10}$ CÂNDIDO, Antônio. Literatura e Sociedade, estudos de teoria e história literária. São Paulo, Companhia Nacional, 1980. (p.4)

${ }^{11}$ Idem.
} 
exerce na composição da obra de arte é investigar as relações entre a obra e o contexto sociocultural, procurando detectar como efetivamente isso é feito em termos estéticos.

Em outro trecho, Ismail Xavier discorre sobre o caráter da figura do narrador de ficções que pode ser uma porta de entrada para a análise fílmica:

"No cinema corrente, e em certa literatura naturalista, a figura do narrador se esconde por trás do seu próprio ato, o qual ele executa com certos cuidados. Não é palpável, não tem rosto, nem nos deixa nenhum outro traço que não seja o ato mesmo de narrar. Pelos cuidados que toma, acaba por provocar em nós uma relação muito particular com a ficção, tal como se esta se desenvolvesse por si mesma e a mediação não existisse, tal como se estivéssemos diante de algo tão autônomo quanto certos acontecimentos de nosso cotidiano. Mas, sabemos, lá no fundo, que estamos diante de um jogo de linguagem, de um faz de conta com o qual desenvolvemos uma relação toda especial e que resulta de uma cumplicidade sutil que envolve a todos. "12

Em linhas gerais, o tratamento da história neste estudo, não pretende ser uma investigação sobre as greves do $\mathrm{ABC}$, utilizando para isso o filme de Leon Hirszman. Mas, uma investigação que considerou necessário compreender como o processo histórico tornou-se um elemento que participa da composição do filme e como a própria "linguagem" cinematográfica incorporou o processo histórico, sem que seja, necessariamente, uma história sobre as greves que despertavam a consciência política dos operários brasileiros. As relações entre história, movimento operário, greves, arrocho salarial, milagre econômico, cinema, linguagem cinematográfica compõem uma síntese difícil e que não necessariamente o filme ajudou a desembaraçar. Mas, a

\footnotetext{
${ }^{12}$ XAVIER, Ismail. Sertão Mar, Glauber Rocha e a estética da fome. São Paulo, Cosac\&Naify, 2007.
} 
percepção dos limites evidentes de uma relação direta e esclarecedora entre filme e contexto histórico, não elimina as possibilidades de uma análise fílmica que tente integrar as dimensões tão aparentemente inconciliáveis, das estruturas internas dos filmes com as determinações de ordem externa da realidade social.

Isso sem falar do caráter polissêmico das imagens e da plasticidade das narrativas, que ampliam as interpretações ou polemizam em relação às categorias utilizadas pela disciplina da história para compreender a realidade brasileira e a história do Brasil. A interdisciplinaridade nem sempre é uma questão bem resolvida e definitiva.

A crítica de cinema, mesmo quando bem feita, é também uma porta de entrada para a compreensão mais integral dos filmes. Há importantes temas e apontamentos que direcionam o nosso olhar para aspectos intrigantes e muitas vezes, também, somos desviados pelas intenções do cineasta que são incorporadas pelos críticos e que se pretendem leituras definitivas sobre os filmes. Cria-se uma fortuna crítica e uma relação entre filme e contexto específico com tema específico, como exemplar de um certo período da história do Brasil. Quando imaginamos que gerações de estudantes mais jovens, levados a assistir esses filmes consagrados como representantes de certos períodos da história do Brasil, podem apresentar interpretações desviantes, inferimos que isso se deve à singularidade dessas obras. O que pelo menos sugere que novas leituras podem ser feitas e que o processo de elaboração da memória (no caso, visual e sonora) é aberto e se encontra em reelaboração constante.

Eles não usam blacktie é um filme que faz pensar na conjuntura brasileira, nas consequências sociais do nosso processo de desenvolvimento urbano e industrial, pela ótica do que experimenta o trabalhador propriamente, sendo, portanto, um filme crítico de nossa realidade social, fruto de nosso processo histórico. Vale ressaltar esse aspecto 
de que o olhar sobre a realidade nacional é construído no filme que analisamos, do ponto de vista dos operários. Mas há

Toda a crise decorrente do fracasso social atribuído ao milagre econômico, que apesar da propaganda e das ambições dos governos militares não correspondeu a uma melhoria significativa das condições de vida da grande massa de trabalhadores brasileiros. $^{13}$ Mesmo com esse significativo pano de fundo socioeconômico, a importância da narração que o filme apresenta não se resume a um mero panorama visual sobre o contexto nacional de então, com aceitação das categorias sociológicas vigentes, mesmo das que provinham dos meios sindicais e operários em ebulição. Tratase de desmontar o que aparentemente está bem amarrado no filme e no contexto que cotejamos com a análise fílmica.

Como o cineasta resolveu na montagem dos filmes, mesmo tratando-se de cinema naturalista, as tensões, as sobreposições entre melodrama, realismo e documentário, é muito significativo todo o processo para compreender as implicações do aspecto formal no plano das significações do filme. As articulações entre ideologias do movimento operário e as interpretações do processo histórico mais amplo, com as temáticas presentes na filmografia do cineasta, e o confronto com a fortuna crítica que contém o ponto de vista do cineasta, e o que podemos aferir desse embate entre o que ele acreditou realizar e o que ele de fato realizou.

O resumo que propomos do filme no trabalho de sua decupagem, forneceu uma interpretação prévia dos procedimentos da montagem, que permite-nos fazer perguntas como, por que essa forma de representar os operários aqui e não outra? Por que essa

\footnotetext{
${ }^{13}$ SKIDMORE, Thomas. Brasil: de Castelo a Tancredo. São Paulo, Paz e Terra, 1989. “(...) O aumento da inflação preocupou muitos que participavam ou não do governo mas, usando a indexação e as minidesvalorizações, o governo pode impedir que as altas taxas inflacionárias distorcessem gravementeos preços relativos. Confrontados com a opção entre baixar a inflação e manter o crescimento, os assessores de Geisel decidiram pelo crescimento"(p.403)
} 
forma de representar a greve? Como as questões políticas são trabalhadas numa perspectiva do cotidiano da família operária? Qual a relação dessas cenas, com as significações que podem ser formuladas quando o filme é considerado enquanto obra de arte e que "transfigura" a realidade que é o seu material de composição?

Eles não usam blacktie é o drama da família operária às vésperas de uma greve, que é considerada pelo pai como mais um momento de reivindicação por reajustes salariais que beneficiariam a todos, enquanto que para o filho é um obstáculo ao seu projeto de sustentar a namorada grávida, já que pode perder o emprego. Esse é o drama central apresentado de forma naturalista. $\mathrm{O}$ enredo do filme é uma adaptação da peça de Gianfrancesco Guarnieri de 1957, montada pelo Teatro de Arena. Mas o filme apresenta muito mais elementos do que a peça, atualizando-a para o contexto de 1979.

Segundo o historiador Thomas Skidmore o contexto de formação do "novo sindicalismo" do ABC apresentava as seguintes características:

“Em 1979 a palavra-chave na política brasileira era 'negociação', o equivalente lógico a abertura para aqueles que desejavam uma nação genuinamente pluralista. A tendência para a negociação, contudo, estendia-se além do cenário político. A imprensa em geral afirmava, por exemplo, que a negociação deveria ser extensiva às relações entre o capital e o trabalho, com o que concordavam calorosamente os 'novos sindicalistas' de São Paulo. Estes passaram então a explorar a abertura política para acelerar o ativismo sindical. A resposta do governo seria um indicador de suas intenções - um teste que não tardaria muito. A experiência das greves de 1978 levara Lula e outros líderes sindicais independentes a planejar uma estratégia diferente quando expirasse seu acordo anual de 1979, que por coincidência era o mês de posse de Figueiredo. A era das greves brancas tão bem sucedidas em 1978, passara, tanto mais quanto não somente o governo federal (através de um novo decreto proibindo greves que afetassem a 'segurança nacional') mas também os empregadores (através de novos 
procedimentos de segurança) estavam muito melhor preparados do que em 1978. Além disso, nada mudara na estrutura legal das relações de trabalho. Em 1978 o governo decidira ser menos rigoroso no cumprimento do código trabalhista (CLT). A liderança dos metalúrgicos do $A B C$ (os três primeiros subúrbios industriais paulistas de Santo André, São Bernardo e São Caetano) estava determinada a um novo teste. Liderada por Lula, convocou uma greve dos seus 160.000 membros em meados de março de 1979 após terem os empregadores rejeitado suas reivindicações. Eles pediam um aumento salarial de 78 por cento, muito acima da inflação oficial do ano anterior, de cerca de 45 por cento. Pediam também reconhecimento legal dos representantes sindicais não oficiais que haviam surgido para concorrer com os pelegos sindicais." (pp.413-414)

Esse contexto é fundamental para compreendermos as discussões políticas entre Otávio que consideramos representante da esquerda "tradicional", e Sartini, companheiro de Otávio, na fábrica e no sindicato, e que representaria esse "espírito da época" manifesto na greve de 1979 dos metalúrgicos do ABC. A combatividade de Sartini não é apenas "porraloquice" como sugerido na crítica severa de Otávio ao seu a comportamento, quando ambos saiam de uma reunião do sindicato, numa das cenas iniciais do filme. Há algo mais nessa contradição entre Otávio e Sartini, que corresponde à forma de apropriação da história como processo contraditório, entre a grande mobilização da greve de 1979 do $\mathrm{ABC}$ e da pequena greve que se esboçava no universo diegético do filme, entre a memória da longa trajetória de resistência à ditadura militar e os desejos egoísticos de Sartini de querer deflagrar rapidamente a greve. Em toda a narrativa, a presença de Otávio é sempre perturbadora da "normalidade" ou do que arriscaríamos chamar de "naturalismo" da representação, dada a sua liderança e seus discursos direcionados a uma abertura ao "passado" que ainda não passou, por isso, é o presente da história de lutas dos operários. E talvez de todos aqueles que, de maneira mais abrangente, inclusive o próprio cineasta, se mantiveram críticos em relação às 
soluções políticas muito "imediatistas". Há uma carga de sofrimento em Otávio que parece remeter a essa memória coletiva da resistência das esquerdas à ditadura militar, e que não pode ser reduzida ao caráter meramente psicológico do personagem melodramático. O drama encenado em Eles não usam blacktie, tanto na peça teatral quanto no filme, deve ser lido para além do melodrama psicológico.

Para Iná Camargo Costa ${ }^{14}$, o problema em representar um assunto político na forma dramática encontra-se na incompatibilidade entre forma e conteúdo. Tomamos por base uma definição que já remonta a Aristóteles sobre o épico em oposição ao drama, que atravessou toda a dramaturgia burguesa segundo Peter Szondi ${ }^{15}$, que tem ressonâncias com as análises de Georg Lucáks, e que corresponde a uma ampla tradição de estudos marxistas sobre a arte dramática ocidental. Ao considerar que a tensão fundamental entre forma e conteúdo foi transplantada para o filme de Leon Hirszman, temos um arcabouço teórico para refletir sobre os movimentos da adaptação que se adequam a um cineasta declaradamente marxista. O uso de certas categorias marxistas, sobretudo da reificação e da alienação são fundamentais para compreender o foco narrativo do filme como posicionamento do olhar diante do mundo.

Nesse sentido, acreditamos que o filme Eles não usam blacktie (1981) de Leon Hirszman, incorpora as tensões políticas da "nova esquerda" com a "esquerda tradicional", na forma "frouxa" em que se construiu o melodrama em seu encadeamento com o realismo crítico e o aspecto documental.

\footnotetext{
${ }^{14}$ COSTA, Iná Camargo. A hora do teatro épico no Brasil. São Paulo, Graal, 1996.

${ }^{15}$ SZONDI, Peter. Teoria da drama moderno (1880-1950). São Paulo, Cosac\&Naify, 2003.
} 


\subsection{O aspecto documental do filme}

ABC da Greve é o documentário, filmado antes de blacktie e que forneceu fonte de pesquisa inestimável para a realização deste, que segundo Jean Claude Bernardet ${ }^{16}$ procurou focalizar o que acontece do lado de fora dos portões da fábrica, como outros documentários feitos naquele período das famosas greves. Para esse autor, ainda, tratase de uma categoria de documentário de modelo sociológico não totalmente isento da busca por uma nova "dramaturgia documentária", como uma apropriação pelo drama de certas “imagens do povo”, próprias do documentário.

Estes dois filmes de Leon Hirszman, compõem uma certa visão sobre a urbanização brasileira em oposição ao imaginário do Brasil rural ou do sertão, como aparece em São Bernardo e no documentário Maioria Absoluta feitos anteriormente. Mas para além dessas classificações gerais, há uma recorrência percebida nos aspectos tações formais destes filmes que remetem a uma preocupação com a educação do intelectual pelo povo. As grandes mobilizações de massas propiciadas pelas greves do $\mathrm{ABC}$, jogavam com uma contradição: o fortalecimento das esquerdas em torno do espontaneísmo do novo sindicalismo do $\mathrm{ABC}$ em sua oposição concreta à ditadura militar, e uma certa desilusão com o abandono do aprendizado "socialista", dentre outros, acumulado pelo PCB e que parecia, agora, relegado ao esquecimento.

Eles não usam blacktie tornou-se um filme histórico, já que as greves do $\mathrm{ABC}$ e Lula tornaram-se referências históricas no processo das lutas sociais e do movimento operário no Brasil como sabemos hoje. ${ }^{17}$ Acreditamos que há um sentido épico original no filme, o que não significa dizer que se trata de um filme épico sobre as greves do

\footnotetext{
${ }^{16}$ BERNARDET, Jean Claude. Cineastas e imagens do povo. São Paulo, Companhia das Letras, 2009.

${ }^{17}$ ANTUNES, Ricardo. A rebeldia do trabalho - O confronto operário no ABC Paulista: As greves de 1978/80. São Paulo, Editora Ensaio, 1988.
} 
ABC. Ao contrário, talvez seja o filme mais crítico ao obreirismo das greves, numa defesa dos objetivos originais da revolução socialista liderada pelo PCB. Não estamos ingenuamente concordando com esta tese, mas tentando partir de algumas hipóteses que serão confrontadas com a análise do filme. Apesar das várias dissidências ${ }^{18}$ e grupos antagônicos que perpassam a história do PCB, decidimos adotar essa sigla para diferenciar o posicionamento de Leon Hirszman em relação a outros grupos de esquerda que correspondam a nossas pretensões de esclarecimento acerca das tensões presentes na forma do filme que analisamos.

Quanto à influência do documentário $\mathrm{ABC}$ da Greve em relação ao discurso das lideranças sindicais e ao espaço urbano para a estrutura do filme que analisamos, não parece mera coincidência que Otávio e Bráulio principalmente, defendam a necessidade imperiosa de "organização" do movimento sindical. Nos planos que tratam diretamente da greve no filme, é Bráulio e Maria quem convocam os companheiros para o "estádio", numa referência explícita ao estádio de Vila Euclides, em São Bernardo do Campo, onde ocorreu o famoso comício em $1^{\text {o }}$. de maio de 1979. Bráulio e Maria são representações da "nova esquerda", enquanto Otávio apoia o movimento grevista, mas não faz referência ao estádio ou às novas lideranças sindicais. Bráulio, Maria e Sartini formariam aqui, uma curiosa conjugação de forças políticas sem a presença de Otávio.

A inserção da história no filme, é perceptível nos detalhes que tornam algumas cenas emblemáticas do enfoque expressivo realista que tenta conectar o melodrama com a história do Brasil, fazendo uso de um registro documental que liga a greve do filme com as greves do $\mathrm{ABC}$. A greve ou as greves do $\mathrm{ABC}$ são assunto dos diálogos (instrumento do drama) mas permanecem evento distante, comparado às dramatizações

\footnotetext{
${ }^{18}$ GORENDER, Jacob. Combate nas Trevas - A esquerda brasileira: das ilusões perdidas à luta armada. São Paulo, Ática, 1987.
} 
da violência policial contra os manifestantes que estão presentes na ação do filme. A ação acelera e diminui, de maneira que contribui para não prender o espectador na continuidade dos fatos narrados, criando fissuras no drama psicológico com as cenas documentais da repressão usada contra os operários tanto nas greves do ABC (19791980), quanto na greve ficcional que estoura no final do filme. Não há cenas das greves do $\mathrm{ABC}$ enxertadas diretamente no transcorrer da narrativa do filme, mas uma construção ficcional que copia literalmente certos detalhes que percebemos no documentário $\mathrm{ABC}$ da Greve. Podemos citar, por exemplo, duas cenas emblemáticas que comprovariam nossa afirmação, como o jogo de bilhar entre Tião e Jesuino, e a cena da prisão de Otávio sendo algemado e empurrado para dentro do camburão da polícia. O jogo de bilhar é citado pelo padre que guia a equipe de filmagem de Leon Hirszman por Santo André, como opção de lazer dos operários. E a cena de prisão, assemelha-se muito a uma cena de repressão presente no documentário em que operários são algemados e jogados na parte traseira do camburão, durante repressão ao movimento grevista.

Há algo da matéria recolhida pelas filmagens do documentário $\mathrm{ABC}$ da Greve (1979) presentes na feitura do ambiente social e político de Eles não usam blacktie. Não há necessariamente uma correspondência cronológica com os eventos que marcaram as partes do documentário que cobriu as greves do ABC de 1979 e 1980, mas algumas transfigurações que legitimam o que foi representado ficcionalmente. $\mathrm{O}$ bar, a linha de montagem na fábrica, os piquetes de greve e a repressão policial, além da passagem do filme marcada pelo ritmo do cotidiano dos operários, são exemplos dessa transfiguração artística do ambiente vivido pelos grevistas reais. O filme apresenta-se, portanto, como uma conjunção entre texto original da peça, pesquisas dos realizadores, contexto 
imediato da realidade social $\mathrm{e}$ as greves do $\mathrm{ABC}$ e $\mathrm{o}$ material audiovisual do documentário ABC da Greve (1979-1989). 


\section{CAPÍTULO 2: PEDAGOGIA DA EMOÇÃO}

\subsection{Análise do filme}

Nas palavras de Leon Hirszman, Eles não usam blacktie é um filme que "parte do folhetim, passa pelo realismo crítico e chega ao épico." ${ }^{, 19}$ Essa afirmação do cineasta não é fortuita, porque remete à questão da forma do seu filme, da própria estrutura dramática que permite uma leitura do filme em duas camadas sobrepostas: o melodrama linear que tem Tião como protagonista, que fura a greve, e a articulação dos outros personagens configurando de maneira alegórica as tensões no campo da esquerda política. O movimento do filme é ora lento ora mais acelerado, mobilizando todos os recursos audiovisuais no sentido de produzir um argumento político sobre a questão operária.

Apesar disso, o filme Eles não usam blacktie é, em linhas bem gerais, um melodrama sobre uma greve problemática do ponto de vista das divergências que provoca entre os operários, considerada a partir de um recorte do cotidiano da família de Otávio, e por extensão, da família operária como classe social. A classe "patronal", é presente como aquela que provoca as demissões, e por isso, temida. É o modelo que orienta os desejos de Tião de vencer na vida, é a identidade dele com o lado vencedor da história, colocando-o contra todos os outros personagens dramáticos.

O combate explícito travado entre pai e filho, é uma representação não somente de opiniões contraditórias, mas da luta de classes como definida por $\operatorname{Karl~Marx}^{20}$. As pressões sociais provocadas pelo arrocho salarial na vida dos trabalhadores brasileiros

\footnotetext{
${ }^{19}$ LORENÇATO, Arnaldo e CALIL, Carlos Augusto. Leon HIrszman, É bom falar. Mostra Leon de Ouro, Centro Cultural Banco do Brasil, 1995. (p.59)

${ }^{20}$ MARX, Karl e ENGELS, Friedrich. Manifesto Comunista. São Paulo, Boitempo, 2007.
} 
não é apenas pano de fundo do drama pessoal, mas é o próprio cotidiano da família operária retratado no filme, em mínimos detalhes como vestuário, mobília e alimentação.

Os elementos de "realismo critico", desde o espaço urbano que se apresenta como cenário natural nas ruas e casas da periferia paulistana, aos locais frequentados pelos operários do filme, como o bar, a fábrica e o ambiente doméstico, estes sim, reiventados por técnicas de estúdio, compõem um circuito fechado. Acreditamos que esse recurso foi proposital para "dissecar" através do olhar concentrado no detalhe da cena, as relações sociais capitalistas reificadas pelo cotidiano. O contraponto a essa economia de descrição do cotidiano operário no filme, seria uma outra descrição onde houvesse a naturalização provocada pela televisão ligada o tempo todo, brigas por motivos fúteis e outras generalidades que ofuscassem a reificação do trabalhador que é explorado no trabalho e "descansa" alienando-se em programas televisivos. O ritmo de vida dos operários representados no filme segue o esquema casa-trabalho-bar sem variações, transpondo em termos cinematográficos, a forma básica das relações sociais de produção/reprodução do capital e do trabalho. ${ }^{21}$

Por outro lado, o elemento forte no filme são as discussões políticas, não somente pelo conteúdo do que está sendo discutido, mas se considerarmos que houve um trabalho de elaboração dramático desse material que se encadeia com as cenas internas e externas nos três ambientes em que o enredo se desenrola. Outro elemento que transformamos em fonte de observação para decifrar os propósitos do filme, são os

\footnotetext{
${ }^{21}$ HARVEY, David. Para entender o capital - Livro I. São Paulo, Boitempo, 2013. “(...) A luta entre capital e trabalho, que encontramos antes no mercado de trabalho, é agora interiorizada na fábrica. Isso ocorre porque a cooperação é organizada por meio do poder do capital" (p.172)
} 
closes gerais externos do ambiente urbano da periferia ${ }^{22}$, local de moradia, de lazer e de trabalho dos operários. Quais seriam as contribuições das excursões da câmera pelo exterior do ambiente social dos operários e como isso está encadeado aos planos e sequências do filme?

O parâmetro que optamos frisar no tocante à crítica jornalística da época de lançamento do filme, subdivide-se, em nossa opinião, em duas abordagens principais. Ou seja, uma vertente mais "otimista" com o resultado final do filme. ${ }^{23}$ E uma outra vertente mais "pessimista" 24 quanto à maneira com que o cineasta procedeu na composição dos personagens principais, e portanto, na significação mais geral que pretendeu atingir no conjunto da obra.

Mas, prevalece na crítica do filme em geral, uma tendência a caracterizá-lo como sendo um drama político e específico sobre as greves de 1979 e até de 1980 no ABC Paulista. Outro parâmetro, não muito definitivo, é a constatação de que o diagnóstico político do filme, sobretudo se considerado à sombra dos embates políticos que agitavam o movimento operário no $\mathrm{ABC}$ Paulista, é muito reducionista. Nossa preocupação é inverter um pouco a ordem dessas premissas interpretativas, indo além dos juízos de valor acerca do filme apenas em função das greves do $\mathrm{ABC}$ e analisar as

\footnotetext{
${ }^{22}$ DAVIS, Mike. Planeta Favela. São Paulo, Boitempo, 2006. “(...) Na verdade, o capitalismo neoliberal, a partir de 1970, multiplicou exponencialmente o famoso cortiço Tom-All-Alone de Charles Dickens em a Casa Soturna. Os favelados, embora sejam apenas $6 \%$ da população urbana dos países desenvolvidos, constituem $78,2 \%$ dos habitantes urbanos dos países menos desenvolvidos, isso corresponde a pelo menos um terço da população urbana global."(p.34)

${ }^{23}$ SALEM, Helena. Leon HIrszman - O navegador da estrelas. Rio de Janeiro, Artemidia Rocco, 1997. “(...) A riqueza do filme é justamente esse fluir das contradições dos personagens, com a suas imperfeições, as suas verdades, debilidades, de maneira a que o espectador tenha absoluta liberdade para se identificar com um ou outro aspecto de cada um deles." Ou seja, a autora considera como positivas essas contradições inerentes na composição dos personagens, o que corresponderia a uma riqueza, porque universaliza-os.

${ }^{24}$ Para outros críticos, como Maurício Segall por exemplo, essas contradições na composição dos personagens são falhas, muito mais do que estilo de composição do cineasta, tornando a mensagem do filme tendenciosa.
} 
particularidades do filme, enquanto discurso cinematográfico, procurando entender a sua estrutura formal.

Com essas definições parciais, iniciamos a análise pelas três sequências finais de Eles não usam blacktie, que, de nosso ponto de vista, estão encadeadas de maneira eficiente e significativa para produzir um efeito específico na feitura do filme. Nessas três sequências finais, se encontram elementos de composição do drama operário que dialogam com outras sequências do filme, tanto no enredo quanto na forma da narração.

O filme apresenta pesquisa elaborada sobre detalhes concretos do cotidiano operário, que atualizam o drama de Eles não usam blacktie de 1957, conferindo ao filme uma abordagem que transcende a perspectiva presente na peça original. ${ }^{25} \mathrm{O}$ filme privilegia a descrição de três espaços principais onde o drama se desenvolve, sendo estes o ambiente doméstico, o bar e os portões da fábrica. Essa construção já apresenta em si, um caráter didático que mais se aproxima de uma apresentação sociológica das condições de vida da classe operária brasileira, do que uma mera caracterização do ambiente como cenário para o drama. Sem menosprezar essa dimensão de realismo crítico que já insinuamos em relação ao "cenário", acreditamos que esta é uma característica do didatismo inerente a praticamente todos os gêneros cinematográficos. Portanto, a relação que percebemos entre realismo e melodrama nesse filme é de predomínio do melodrama no inicio da narrativa e uma inversão para o realismo nas sequências finais. $\mathrm{O}$ escopo do melodrama tende a ser mais moralista, enquanto no realismo, um pouco mais político. $\mathrm{O}$ aspecto político se sobrepõe ao moralista no desenrolar da narrativa e somos levados a valorizar mais a opção coletiva do que a opção individualista.

\footnotetext{
${ }^{25}$ Idem, nota 21, (p.256) "Leon e Guarnieri recorreram a uma farta documentação sobre o movimento sindical e a assessorias diversas de cientistas sociais, gravando as próprias discussões e reflexões, procurando mergulhar o mais fundo possivel naquele universo da classe operária paulista."
} 
$\mathrm{Na}$ verdade, como tentaremos demonstrar pela análise a seguir, essa sobreposição do realismo ao melodrama é construída desde a primeira sequência, e portanto, o movimento geral do filme é o mesmo que observamos em cada uma de suas partes. Começamos a nossa análise, pela parte final do filme, e tentamos desenvolver os elementos percebidos nas três últimas sequências, dentro de uma perspectiva histórica. Tanto na peça teatral quanto no filme, o conflito entre pai e filho é o elemento estrutural central, por meio do qual, toda a discussão política e os seus significados podem ser articulados num discurso coerente. A parte conclusiva do filme, também, nos oferece a perspectiva da força expressiva ou "alegórica" de cada personagem e dos seus limites intrínsecos.

No filme, sobretudo, prevalece uma perspectiva aberta sobre a história, ao contrário do "circuito fechado" em que observamos as relações humanas do ponto de vista do enredo (casa-fábrica-bar), apontando para o futuro. Otávio e Tião são, em linhas gerais, os extremos entre militância política e alienação política. Mas, ao mesmo tempo, como alegoria funcionam como um divisor de águas entre os sonhos da esquerda socialista e o fim das ilusões em conformidade com a radicalização da resistência operária no $\mathrm{ABC}$ paulista. ${ }^{26}$ Havia diferenças não apenas entre o que poderíamos considerar "engajamento político" versus "alienação política", no par dramático Otávio e Tião, cuja tensão aumenta significativamente, devido ao fato de serem pai e filho. Havia diferenças na próprio campo da esquerda que fazem de Otávio um personagem tão “austero" não apenas em relação ao filho, mas também, quando se trata dos próprios

\footnotetext{
${ }^{26}$ NEGRO, Antonio Luigi. Linhas de Montagem - o industrialismo nacional-desenvolvimentista e a sindicalização dos trabalhadores (1945-1978). São Paulo, Boitempo, 2004. “(...) Consequentemente, no final de 1978, a classe trabalhadora estava novamente municiada do somatório rodinhas, comissões, bairros, piquetes e sindicatos, equação imprescindível às greves da categoria metalúgica do $A B C$, em 1979 e 1980. Ao desejarem representar suas bases com autenticidade, sindicatos e partidos do pós-78 sancionaram, de novo, aquela mesma indiferença com que os movimentos grevistas do pré-1964 recebiam a linha de proteção à indústria e burguesia brasileiras. A luta pelo direito de greve não reconheceria o verde-amarelo no chão da fábrica."(p.311)
} 
companheiros de fábrica. Não se trata, pois, de uma abordagem reducionista da condição humana que opõe um pai cabeça dura, antiquado, a um filho que desejava ser independente, inclusive do passado opressivo de sua própria classe social, para "vencer na vida", ingressando de vez no consumismo que rondava o mundo operário. Aqui, voltamos ao "circuito fechado" citado mais acima, aonde Tião e Otávio parecem respirar com muita dificuldade e, em que ambos, cada um da sua forma, pretendem se libertar. Ou seja, Tião quer alçar vôo, fugir da esfera opressora do destino ao qual a sua família parece acorrentada, e realizar a grande promessa de enriquecer e dar uma vida confortável para a esposa e o filho que nascerá em breve. Otávio, por sua vez, demonstra enorme dificuldade em lidar com o seu companheiro de fábrica Sartini. O posicionamento radical de Sartini parece ir contra tudo o que Otávio acreditou até então, de maneira que ele, ora apoia-o, ora recrimina-o veementemente. Na sequência de planos que acompanhamos o estourar da greve, com todo o aparato policial de repressão agindo sobre os trabalhadores grevistas, Otávio mesmo contrariado, apoia Sartini nos piquetes conclamando os companheiros para que aderissem. Numa sequência anterior, Otávio discute com Sartini sobre as razões da greve, demonstrando que suas ideologias eram completamente contraditórias. Nas discussões entre Otávio e Tião que procuraremos demonstrar no decorrer da presente análise, percebemos que há uma certa equivalência entre os dois personagens.

Em primeiro lugar, ambos são pais, um já é um pai veterano enquanto outro será pai em breve e ambos, acreditam estarem fazendo o melhor por suas famílias. Ambos possuem também mulheres "comprometidas" com o casamento e em certo sentido, com a causa operária. Romana é crítica em relação à militância do marido, mas chegamos a compartilhar de sua determinação e conhecemos sua história, para manter a unidade do lar mesmo quando Otávio estivera preso. Maria se inspira em Romana, e parece almejar 
constituir uma família com o mesmo histórico de lutas e companheirismo. Mas Maria desde o princípio, percebe o medo de Tião em "comprometer-se" com os ideais que animam todos os seus companheiros de fábrica, pelo menos daqueles que ela conhece. Ou seja, o mundo de Maria são os companheiros e companheiras de fábrica, e as reivindicações salariais são parte disso. Na peça teatral, a catarse é justamente na parte conclusiva quando Maria acusa Tião de sentir medo e por isso, ter furado a greve e traído a comunidade. No filme, este medo já está destacado no comportamento de Tião e o que era "comunidade" na peça teatral, virou "sindicato" no filme.

Em segundo lugar, a família é o núcleo onde, na prática, ocorre a produção e a reprodução social da existência dos indivíduos, como analisado por Friedrich Engels em seu Origem da Família, da Propriedade e do Estado. Dentro da família, ou a partir dela, é que os indivíduos são formados para a vida social. A família não é uma mônada, como o autor citado acima expõe, mas é o lugar onde cada indivíduo é iniciado nas relações sociais capitalistas propriamente ditas.

Em terceiro lugar, tanto Tião pelo já exposto até aqui, quanto Otávio, pelo que diremos a seguir, mantém uma relação "tensa" com os outros personagens do enredo. Ou seja, Tião polariza toda a dimensão alienada do individualismo quando confrontado com o pai e todos os outros personagens que representariam a dimensão coletiva. Mas, Otávio também representa outra "tensão" com Sartini, dentro do campo que chamaremos o da "esquerda como representada no filme". Nesse sentido, Maria e Braúlio são mais incisivos que Otávio no tocante à reunião no sindicato, numa clara alusão ao que realmente estava acontecendo no $\mathrm{ABC}$ paulista. $^{27}$

\footnotetext{
${ }^{27}$ Idem. (p.311) “(...) A nova fase das lutas sociais contra a ditadura encontrou um PCB destroçado pela repressão política e arruinado por cismas e críticas. Vários setores da sociedade civil se aproximaram do Novo Sindicalismo e, na pauta de ambos, constavam, lado a lado, a definição de sua identidade (apontando rumos) e a memória a ser construída sobre o passado, discutindo 1964 e 1968."
} 
Consideramos que há o mesmo princípio formal ${ }^{28}$ estruturando todas as partes do filme, e nas sequências finais irrompe o que chamaríamos de uma determinada pedagogia da emoção, que se encontra na forma como a instância narrativa conduz o olhar do espectador. Ao procurar compreender o significado geral do filme procuramos atentar para as particularidades de composição das cenas, a maneira como o enredo estrutura-se para atingir esse objetivo.

Procuramos perceber como o espaço da periferia e o tempo contemporâneos da lógica capitalista hegemônica nos anos 1980 compõem uma realidade que oprime os operários, incorporadas na tensão ideológica entre pai e filho presentes na narrativa do filme ${ }^{29}$, no registro ficcional sobre o cotidiano da família operária, extrapolando o drama teatral original da peça Eles não usam blacktie de 1957.

Começaremos subdividindo o filme em blocos de análise e então, tentaremos descrever como a cena dos feijões se encadeia nessas sequências finais, concentrando e "amarrando", o argumento principal do filme. A cena dos feijões é fundamental para caracterizar o filme como também relevante do ponto de vista formal, já que a crítica em geral despreza nesta cena qualquer relevância do ponto de vista político.

Consideramos que é necessário compreender o modo como a contradição entre as posições políticas do pai e do filho são apresentadas durante a narrativa, para

\footnotetext{
${ }^{28}$ CÂNDIDO, Antônio. A dialética da malandragem. In: O discurso e a cidade, 12a . Edição, Rio de Janeiro, Ouro sobre Azul, 2011. “(...) OD, dialética da ordem e da desordem, é um princípio válido de generalização, que organiza em profundidade tanto $A B$ quanto $A^{\prime} B^{\prime}$, dando-lhes inteligibilidade, sendo ao mesmo tempo real e fictício - , dimensão comum onde ambos se encontram, e que explica tanto um quanto outro. $A^{\prime} B^{\prime}$ não vem diretamente de $A B$, pois o sentimento da realidade na ficção pressupõe o dado real mas não depende dele. Depende de princípios mediadores, geralmente ocultos, que estruturam a obra graças aos quais se tornam coerentes as duas séries, a real e a fictícia. (p.46) ${ }^{29}$ XAVIER, Ismail. Sertão Mar - Glauber Rocha e a estética da fome. São Paulo, CosacNaify, 2007. “(...) Em outros termos, preocupei-me com o 'foco narrativo' (foco no sentido de ponto de onde emana, fonte de propagação): sua caracterização nos diferentes filmes e os significados sugeridos pelo comportamento do narrador em cada caso. Perguntei sempre: Como se conta a estória? Por que os fatos são dispostos deste ou daquele modo? O que está implicado na escolha de um certo plano ou movimento de câmera? Por que este enquadramento aqui, aquela música lá?". (p.16)
} 
escaparmos de uma mera constatação excessivamente normativa do maniqueísmo entre opostos absolutos. Além disso, a "cena dos feijões" se encaixa estrategicamente no epílogo do filme, anunciando o terceiro aspecto descrito na frase de Leon Hirszman citada no início desta dissertação, acerca do caráter "épico" existente no seu filme. O sentido épico aqui, também não será exagerado, mas procuraremos elucidar dentro de uma perspectiva teórica específica ${ }^{30}$, e como elemento utilizado de maneira prática na realização do filme. O resumo que propomos a seguir já é parte do nosso esforço de encaminhar uma certa interpretação do filme, já é a própria análise do conteúdo e de alguns aspectos da forma que consideramos relevante destacar.

${ }^{30}$ SZONDI, Peter. Teoria do drama moderno (1880-1950). São Paulo, Cosac\&Naify, 2003. 
BLOCO 1: O segredo de Maria e a greve anunciada

A música tema de Adoniran Barbosa e Gianfrancesco Guarnieri, "Nóis não usa as blequetais", principia com acordes de violão e o título do filme se inscreve na tela e abaixo do título, está a descrição de que se trata de adaptação da peça Eles não usam blacktie dos anos 50. De uma cena desfocada, vão surgindo Tião e Maria, jovem casal que sai do cinema e abraçados caminham pelas ruas de um pequeno centro comercial, atravessando vitrines de lojas e se dirigindo ao ponto de ônibus. A câmera faz vários closes do casal, assumindo diversos ângulos, o que será uma constante durante o filme. A câmera apresenta-se como elemento bastante ativo no encaminhamento da narrativa.

Na sequência seguinte, Tião e Maria estão no interior do ônibus e chove torrencialmente. Maria ensaia um suspense para revelar um segredo ao namorado, mas mantém-se firme. Acompanhamos a chegada do ônibus com letreiro Brasilândia que para, enquanto o casal salta e começa a descer uma rua lateral que nosso olhar visualiza pelas costas de Tião e Maria. Ao fundo, visualizamos movimentação na frente de um bar e um camburão branco e preto estacionado. Conforme o casal vai se deslocando pela rua, a câmera assume a perspectiva de dentro do bar e presenciamos o que acontece ali e o casal passando ao fundo. Inverte-se a perspectiva. Trata-se de uma batida policial e o enquadramento dos frequentadores do bar. O dono do bar argumenta em defesa de um dos sujeitos, maltrapilho, descabelado, portando um violão, mas que pelo visto não portava carteira de identidade na ocasião. Um outro sujeito negro é posto algemado dentro do veículo, enquanto o violeiro passa a ser agredido por um dos policiais à paisana. A perspectiva volta a enquadrar Tião e Maria que comentam a cena e prosseguem rumo à casa de Tião. Durante todo esse trajeto, chove sem parar e a trilha sonora contribui para aumentar a melancolia do quadro. Pela rua enlameada, o casal prossegue e entra na casa de Tião. 
Inicia-se uma sequência dentro do ambiente familiar de Tião, com a câmera posicionada de forma fixa enquadrando todos os atores, que contracenam se movimentando, ora uns ora outros e ora todos aparecem nos closes, juntos. O espectador pode conhecer todos os personagens principais do drama: Tião, Maria, Otávio e Romana, pais de Tião. Sucedem-se basicamente duas cenas importantes que fecham esse primeiro bloco

Maria vai finalmente revelar a gravidez a Tião que fica nitidamente dividido entre a alegria da notícia e a preocupação com a precariedade da situação atual deles. Configura-se um embate que expõe abertamente a condição da vida operária e a dificuldade em se criar um filho, e ao mesmo tempo, a necessidade de responder rápido à situação, acertando um noivado. Ambos decidem comunicar às famílias o noivado, mas não a gravidez. Mas, para o espectador uma das razões do drama está colocada. A segunda cena principia-se quando Otávio surpreende-se em encontrar os jovens em sua casa àquela hora, pendurando o guarda-chuva na parede e falando como que movido por uma súbita animação. Comunica a ambos a iminência de uma greve para ajustar contas com os patrões. Daí, tomamos conhecimento que os três trabalham como operários na mesma fábrica e percebemos a outra razão do drama ou a primeira impressão de tensão que é o anúncio da greve feito por Otávio.

Como complemento do quadro, Romana a mãe de Tião, repreende todos os barulhentos da casa, convocando-os a se recolherem para suas camas. Romana toma conhecimento tanto do noivado quanto da greve, e já tensiona com as possíveis ambiguidades resultantes de tão inusitada combinação de fatores em suas vidas. Estão colocados os elementos constituintes da narrativa do filme Eles não usam blacktie, que em relação ao texto da peça homônima de 1957, manteve o drama, mas aprofundou as 
ambiguidades entre as dimensões pública e privada em que transcorriam a existência daquela parcela que corresponde ao recorte da população brasileira feito pelo cineasta.

Acompanhamos Tião e Maria até a entrada da casa dela. Ela evita um encontro com o pai na sala e entra pela janela ajudada pelo irmão adotivo. Maria troca de roupa, atravessa a sala atrás do pai, bêbado assistindo tv, em direção ao quarto da mãe. Conhecemos os problemas da família de Maria: alcoolismo do pai e doença da mãe. Segue-se uma cena de ofensas verbais do pai à filha que se recolhe à sua cama e olha o teto pensativamente. Apaga-se a luz. 
BLOCO 2: Caminhos paralelos

Esse bloco corresponde ao domingo seguinte a todos os acontecimentos do primeiro bloco que se deram sábado à noite e aos demais dias da semana que antecede a semana da greve. É o único dia de lazer em toda a narrativa em que acompanhamos três períodos: manhã, tarde e noite. Nos outros dias tratados nesse bloco de análise, acompanharemos apenas momentos de um período de trabalho ou de um período de lazer. No total, são duas semanas entre o primeiro bloco que descrevemos e a greve propriamente dito.

No domingo pela manhã, nos encontramos com Tião jogando bilhar e bebendo cerveja, no mesmo bar do prólogo do filme. Romana passa com Chiquinho (irmão mais novo de Tião), Terezinha (namorada de Chiquinho) e uma vizinha, carregando sacolas de feira. Romana exorta Tião para que não deixe de almoçar em breve. Tião continua à mesa jogando bilhar, quando Gesuíno se aproxima. Compartilham do bilhar e da cerveja. Segue-se uma cena com o violeiro maltrapilho das primeiras sequências, que pede uma cachaça e é servido pelo Alípio, dono do bar que intercedera por ele também naquela ocasião.

Agora, estamos dentro do bar com Tião e Gesuíno conversando sobre a greve e a gravidez de Maria. Conhecemos Gesuíno, que é personagem coadjuvante, mas que encarna todo o estereótipo do mau caráter ou do típico vilão do melodrama. Gesuíno propõe a Tião espionar os operários na fábrica para obter promoções junto à gerência. Tião não concorda com a posição e Gesuíno e prefere defender abertamente o que acredita: que furar a greve é defesa de um direito. Enquanto isso, somos transportados para outra cena em que Otávio, Bráulio e outros operários distribuem panfletos da greve para as pessoas que saem da igreja. Surgem camburões da polícia, sirenes ligadas, que 
fazem os operários se refugiarem no interior da igreja. Bráulio e outro operário fazem o sinal da cruz, mas não há uma caracterização muito segura para afirmarmos que foi incluída no filme uma referência a atuação das $\operatorname{cebs}^{31}$, que naquele contexto tiveram grande papel na resistência à ditadura militar. Otávio e outro operário não fazem o sinal da cruz, denotando que são apenas militantes do sindicato. Assim, são apresentadas duas vertentes do movimento operário brasileiro da época. E numa montagem que apresenta as diferenças entre pai e filho, entramos em contato com os seus caminhos paralelos.

Somos levados a seguir para uma tarde de domingo no teleférico, represa, cachorro quente, e muitas pessoas aproveitando o tempo de lazer. Tião e Maria combinam ir à casa da Silene, amiga operária de Maria. A câmera passeia pela paisagem urbana dos trilhos e pela passagem do trem, a trilha sonora nos conduz para a intimidade de uma cena mais erótica entre Tião e Maria. Há um corte rápido da cena e acompanhamos numa outra cena a saída de Otávio, Bráulio, Sartini da sede do sindicato, onde supostamente passaram o dia debatendo a situação da classe trabalhadora e a necessidade da greve. Outro corte e estamos novamente com Tião e Maria que se despedem em frente à casa dela, combinando irem juntos para a fábrica na manhã seguinte.

Sucede uma cena curta que envolve emotivamente Maria e seu pai. Sóbrio, o pai de Maria felicita a filha pelo noivado e anuncia que voltará a trabalhar. Pequena cena de reconciliação entre pai e filha, que reitera em certa medida, os pressupostos canônicos do melodrama. Logo a seguir o mesmo procedimento formal irá se repetir com Tião e Otávio em mais uma pequena cena de reconciliação, que fora interrompida, porém, pela

\footnotetext{
${ }^{31}$ Comunidades eclesiais de base da igreja católica que tornaram-se focos de resistência à ditadura militar.
} 
ocorrência de uma tragédia no bar do Alípio. Um jovem negro em nítida condição de marginalizado, portando arma de fogo, invade o bar exigindo abrigo porque estava sendo perseguido por policiais fortemente armados. Através de uma elipse acompanhamos um assassinato porque ouvimos os tiros mas não o assassinato do rapaz negro, enquanto a câmera fixa os rostos tensos das testemunhas Otávio, Tião, Alípio e o violeiro anônimo, encerrando a cena.

Há um close final do rapaz ensanguentado na rua de terra, camburões e policiais em volta, no silêncio do bairro. Apesar da possibilidade clara de reconciliação entre pai e filho, o diálogo deles aprofunda as divergências instauradas nas sequências iniciais do filme e que ressaltamos no bloco 1. Os caminhos paralelos trilhados por pai e filho, demonstram as divergências de posicionamento quanto as opções de reivindicar uma vida melhor. O pai posiciona-se favorável à opção coletiva de mobilização e de enfrentamento com as forças do regime (no caso, a ditadura, o governo, os patrões) e o filho argumenta em favor da opção individual. A forma como a conversa entre pai e filho é encenada e o conteúdo da discussão, correspondem à nossa hipótese de que o princípio organizador do filme é pedagógico. É um diálogo pedagógico em que o pai procura convencer o filho a ampliar seu horizonte estreito, porque despolitizado, em comparação com o dele, e o filho retruca afirmando que o seu posicionamento é consciente. Aliás, o trágico que o filme pretende construir e que começa a esboçarnessas sequências que chamamos de bloco 2 , está em que Tião tem consciência da sua verdadeira situação de classe, mas que opta por renunciar ao que ele considera um caminho para o fracasso. 
BLOCO 3: A semana que antecede a greve

A greve é o grande acontecimento, diante do qual tudo o mais gira em torno. Neste bloco, acreditamos estarem os motivos para a greve e para a precipitação dos acontecimentos principais da narrativa do filme. Após o desfecho da cena sombria do bar e do assassinato do jovem negro pela polícia, acompanhamos a entrada da fábrica lotada de trabalhadores, segunda-feira de manhã, ensolarada e formando mesmo uma antítese com a sequência anterior. Tião e Maria se despedem e combinam voltarem juntos do trabalho para casa. Otávio, Bráulio, Sartini e outros operários tomam conhecimento de demissões promovidas pela gerência da fábrica, de companheiros que agitavam a greve. Pelo lado das operárias, também ocorreram demissões. Instaura-se uma tensão que marca o começo da semana para os trabalhadores.

No vestiário, Otávio, Bráulio e Sartini divergem sobre o encaminhamento da greve. Gesuíno passa por eles e se solidariza com os companheiros demitidos. Seguemse alguns planos na linha de montagem, de Maria e de Otávio trabalhando. Tião trabalhava com o maçarico quando é chamado por um funcionário para comparecer ao departamento pessoal da fábrica. O mesmo departamento pessoal que na sequência anterior, promovera as demissões dos operários.

Inicia-se uma sequência de planos em dois ambientes internos: o refeitório da fábrica e a mesa de jantar da casa de Otávio e Romana. No refeitório da fábrica, Tião e Gesuíno divergem acerca da moral e da ética de comportamentos no que diz respeito a ascensão social. O que seria realmente legítimo para ambos parece claro: para Tião trata-se de assumir uma posição e defendê-la como um direito, para Gesuíno há o imperativo de levar vantagem sobre outros. Aqui se estabelece uma separação interessante entre o que Tião almeja e a sua maneira de atingi-lo. Ele não é o típico vilão 
do melodrama, ele assumiu o lado do individualismo em comparação com o coletivismo, procurando manter certa dignidade. A verdadeira tensão ideológica irrompe entre Gesuíno e Sartini, apesar de ambos nunca terem trocado palavras no desenrolar do drama. Esse é um dos pontos que pretendemos desenvolver mais em nossa análise.

Close geral ou tomada aérea do portão da fábrica, operários saindo, fim do turno. Estamos posicionados na mesa de jantar da casa de Otávio, com toda a família ceando uma sopa fumegante trazida por Romana. Toda a família é enquadrada na cena, compondo um momento muito realista no filme sobre o cotidiano dos operários. Durante o jantar, Otávio e Tião discutem sobre a demissão dos operários envolvidos com a greve. Otávio solicita mais participação de Tião nas reuniões do sindicato. Tião, por sua vez, adverte o pai porque sabe que as demissões foram provocadas pelo mecanismo de delação-promoção praticado pela gerência da fábrica, cujos detalhes Gesuíno revelou na refeição em que conversaram horas antes desta discussão familiar. ambos desabafam seus pontos de vista divergentes. Encerra-se a discussão com Tião deixando a mesa de jantar e batendo a porta do seu quarto. Close no rosto de Romana expressa a tensão reinante no ambiente familiar.

A primeira conversa entre Tião e Gesuíno guarda pontos de convergência com a segunda, que é mais dramática, mais tensa, mas que não se traduz como uma discussão política propriamente. Apesar da aparência de que se trata de discussão política, pela existência evidente de dois polos antagônicos representados pelo pai e pelo filho. Mas o filme nos arrasta para uma percepção de que o que estamos observando é mais uma sobreposição de discursos ideológicos, do que uma oposição categórica entre alienação do filho e engajamento do pai. No primeiro caso, Gesuíno expõe as regras do jogo que se joga na prática social reinante, por mais imoral ou desonesto que seja. Tanto que Tião 
manifesta discordância com Gesuíno pela exposição fria e direta de algo que não deveria ser como é.

Na manhã seguinte, Tião conversa com a mãe que o convence a reconciliar-se com o pai. Do ambiente familiar, somos levados para a saída da fábrica onde Otávio e Bráulio consolam Sartini que fora despedido nesse dia. Eles se encontram num trailer em frente à fábrica, enquanto tomam cachaça, discutem sobre o caráter político das demissões. Do fim de tarde em que essa cena de operários conversando no trailer em frente à fábrica somos conduzidos para outro quadro: Tião, Maria namorando quando o pai de Maria, Jurandir, demonstra carinho com a filha e numa fala rápida defende o discurso do trabalhador não-organizado. Jurandir desempregado começaria a trabalhar no dia seguinte na construção civil. Tipo de emprego que abrangia grande parcela de migrantes nordestinos em São Paulo. Em síntese, o que ele afirma é algo parecido com a expressão de que o "trabalho dignifica o homem". Há um contraponto entre trabalhadores organizados e não-organizados.

Desta cena em frente à casa de Maria, amanhecemos com Otávio segurando uma xícara de café, observando a paisagem urbana, posicionados às suas costas pela posição da câmera. Um som instrumental melancólico ao fundo compõe, junto com Otávio tomando café e a paisagem das casas e ruas do bairro, um quadro sentimental e belo ao mesmo tempo. O homem no seu recolhimento, com a tristeza do cotidiano pesando sobre si, quando ninguém repara. Tião toma café da manhã e se desculpa com o pai. Ambos conversam e Otávio revela sua desconfiança de que Maria está grávida. Ambos se reconciliam e tudo parece encaminhar para um desfecho que recolocaria Tião ao lado do pai, contra Gesuíno. Pelo menos, em termos de posicionamento em relação à greve, a narrativa abre a perspectiva de que pai e filho acabariam se entendendo. 
Close geral num edifício em construção, trabalhadores descendo num elevador típico nessas construções, dentre os trabalhadores Jurandir, pai de Maria. Este pede um adiantamento ao seu benfeitor, aquele que teria arranjado o emprego para Jurandir. A alegação era de que o adiantamento serviria para pagar uma dívidas, mas reencontramos Jurandir cambaleante, retornando para casa por matagais escuros, bêbado. Ele é abordado por um homem armado que aponta o revólver, pedindo dinheiro. Antes disso, há um plano intercalado mostrando Tião, Maria assistindo tv, a mãe de Maria preocupada com a demora do marido e Bié, o menino adotado por Jurandir, jogando futebol de botão num quarto contíguo à sala de estar. Todo esse movimento enquadrado pela câmera numa movimentação parecida com aquela do inicio do filme na casa de Tião. Voltamos a Jurandir, que por estar bêbado não avalia o risco de sua atitude de passar pelo assaltante sem ser molestado. O homem atira em Jurandir. Numa pequena cena intermediária entre o assassinato e o velório, vemos novamente o violeiro anônimo que ouve os disparos e olha para a escuridão. $\mathrm{O}$ violeiro encontra-se entre muitas pessoas reunidas na casa de Maria.

No centro da cena o caixão com o corpo de Jurandir, em volta cadeiras, Romana prepara café ao fogão no fundo, Otávio sentado com os demais, Tião e Maria estão na porta. A seguir, nos encontramos fora da casa, e de maneira quase imperceptível ouvimos o comentário de que o IML demorou para liberar o corpo para a família. Tião e Maria conversam modificando o plano original de arrumarem casa para morar, porque Maria prefere ficar com a mãe e Bié. Otávio aparece para consolar Maria. Maria rejeita descansar na casa de Otávio e diz que quer ver o pai, que nunca antes vira realmente o pai. Acredito que além do realismo da cena, há um simbolismo nessa morte de Jurandir que gostaria de desenvolver no transcorrer da análise. No mais, a referência à violência urbana e, sobretudo, a violência nas periferias da cidade é explícita. Mas, para além 
dessa referência quase documental, vou me esforçar para traduzir essa tragédia na diegese do filme. Algo que parece uma "digressão" no interior do drama principal das escolhas individuais e coletivas que o encadeamento das sequências do filme, ou os blocos que estamos considerando como unidades de análise, têm sugerido.

Os planos finais desse que consideramos o terceiro bloco de análise, apresenta Otávio e Romana conversando sobre a gravidez de Maria, e quando iniciavam uma cena de amor, batidas à porta fazem Otávio se levantar. Bráulio chega trazendo a noticia de que a "turminha do berro" ganhou dos mais comedidos, e a greve está marcada para segunda-feira. 
BLOCO 4: Preparativos de greve

Estamos, provavelmente, numa sexta-feira, porque na próxima sequência de planos, nos encontramos num campo de futebol, onde atrás de um dos gols, vários homens jogam bocha. Dentre eles, está Sartini, alvo dos gritos de Otávio seguido de Bráulio. Esse encontro no campo de futebol aumenta a tensão dramática com que a narrativa vinha se desenrolando. São expostas razões contrárias para justificar as posições políticas de cada um. Otávio acusa Sartini de provocar a greve por ter sido demitido, Sartini por sua vez, retruca dizendo que há boatos de que Tião teria dedurado ele para a gerência da fábrica. Ambos ameaçam se agredir, quando são separados pelos companheiros e Bráulio chama a todos para o bom senso. Sua afirmação de que a política não deve misturar questões pessoais acalma os ânimos. Essa cena se passa num domingo pela manhã. Domingo à noite, no sofá da casa de Maria, todos assistem tv. A mãe de Maria se retira para dormir, Bié também, restando Maria e Tião que discutem sobre a participação deles na greve. Tião explode sua ira exigindo que Maria não se meta em confusão de greve, Maria suspeita que Tião pode furar a greve. 


\section{5: A GREVE}

Na manhã de segunda-feira, um plano rápido demonstra a chegada de camburões de polícia que estacionam em frente à fábrica. No plano seguinte, estamos novamente à mesa do café preparada por Romana, Tião corta o pão e conversa com a mãe que estranha o fato de Tião sair antes do pai. Romana pede cuidado ao filho e demonstra amor maternal. Seguem-se planos com Romana arrumando cartas, Chiquinho dormindo no sofá, Otávio tomando café e conversando com Romana. As mesmas recomendações feitas ao filho. Otávio sai, Romana chama Chiquinho para o trabalho, arruma a mesa e lê suas cartas prevendo problemas.

Entrada da fábrica em perspectiva, vários trabalhadores entrando, policiais enfileirados a esquerda, camburões estacionados à direita. Policiais se movimentam e começam a dispersar os grevistas que tentam fazer piquetes. É o início de vários planos sucessivos que retratam a repressão policial contra os grevistas. O registro documental é parte fundamental na composição da narrativa. Também é possível perceber a mistura de cenário e registro documental, entre cenas mais típicas de estúdio com cenas mais realistas. O movimento do filme é uma interessante composição de melodrama, drama, realismo e tragédia, onde tempo e espaço jogam um papel preponderante situando historicamente a contingência da vida cotidiana e o espaço precário da cidadania.

Num dos piquetes, Sartini se irrita com os operários fura-greves e tenta força-los a aderir ao movimento grevista. Otávio e Bráulio impedem-no, comparando essa atitude à dos policiais. Os policiais agridem os operários que correm, Otávio, Bráulio e Sartini correm para a frente da fábrica, quando avistam Tião. Otávio tenta desesperadamente deter a entrada do filho na fábrica. Mas, ouve de Tião que a greve já estava gorada antes mesmo de começar. Otávio põe-se a discursar para os operários grevistas e todos são 
duramente reprimidos, sendo Otávio algemado e levado para o camburão. Antes de entrar no camburão, Otávio afirma para o espectador : “É assim que tratam o proletário brasileiro!", numa forma de expressão brechtiana encoberta pela expectativa dos operários que ouviam seu discurso anteriormente no próprio espaço da encenação diegética.

Há nessa fala dirigida ao espectador, mas disfarçada pelo recurso diegético de fala dirigida a outros personagens mantendo o naturalismo da representação, algo que obviamente é bastante impactante pelo contexto das greves do $\mathrm{ABC}$ e que tensiona com esse mesmo naturalismo da representação. Essa tensão entre forma e conteúdo, que é um elemento de composição do filme a ser ressaltado, prepondera nos momentos do filme em que se procura dramatizar as ações políticas que na peça não passavam de elipses. Nesta cena, em particular, Leon Hirszman captura o momento político que Emir Sader denominou como "os novos sujeitos irrompem à cena". Otávio é o próprio Leon Hirszman, e se apropria da voz das ruas, da voz antes silenciada, para sobrepor a “questão operária", a uma possível "questão democrática" com enfoque liberalizante a que o filme poderia decair.

Tião assiste à prisão do pai e continua firme no propósito de trabalhar. nesse conflito densamente encadeado, não há apenas divergência entre pai e filho, mas sobretudo, questões de consciência de classe, questões políticas, questões de conflito do indivíduo com as reivindicações coletivas dos trabalhadores. Tião utiliza a expressão democracia, Otávio fala a respeito do direito de greve. Há aqui uma das linhas mestras de entendimento do filme, numa sobreposição de discursos mais do que tensão entre opostos, diferente da que ocorre entre Gesuíno e Sartini os extremos da militância e do oportunismo. Mas de qualquer forma, é preciso marcar as diferenças entre eles, já que é visível a militância de Otávio frente à solução individual tentada por Tião. 
Após a sequência descrita acima, uma nova cena se abre com a explosão de uma bomba de efeito moral, dispersando a multidão que grita aterrorizada. A repressão segue as ordens recebidas, porque há uma nítida investida de policiais sobre os grevistas. Em todo o filme, a esfera do poder não é representada, mas se faz presente. Maria e Silene correm para fugir das bombas, e a fala de Maria é bastante sugestiva: "Calma, Silene, calma! Eles não podem obrigar a gente a entrar não! Eles tão querendo intimidar a gente. Nós vamos tomar essa luta de frente! Defender nossos direitos!" Maria parece discursar para o espectador, da mesma maneira que na sequência anterior, Otávio se dirige a um hipotético público de operários que assistia à sua prisão. Maria se dirige a Silene, mas demonstra elevada consciência da luta de classes (eles contra nós), ensinando Silene que ainda é inexperiente em greves. Otávio e Bráulio fazem isso com Sartini o tempo todo. Maria e Silene correm, esperam as companheiras, e quando se preparam para ir ao estádio, são abordadas por policiais à paisana, que as intimidam. Um deles atinge um soco na barriga de Maria, que é socorrida pelas operárias. Há uma referência à reunião no estádio (provavelmente alusivo ao estádio de Vila Euclides onde os metalúrgicos do $\mathrm{ABC}$ se reuniram em suas jornadas), utilizada por Maria, Bráulio e Sartini durante os piquetes de greve.

Como afirmaram Marco Aurélio Santana e Ricardo Antunes :

"O resurgimento do movimento dos trabalhadores reassumia, a partir especialmente das greves de 1978, o lugar que já tivera no cenário político nacional (quando de pensa, por exemplo, nos anos 1945-1947 e especialmente no período que antecedeu o golpe de 1964). E esse ressurgimento vigoroso do movimento operário e sindical trouxe novos dilemas e enormes 
desafios para o PCB, que acabaram abalando fortemente sua capacidade de dirigir politicamente a classe trabalhadora." $(p .383)^{32}$

Outra tomada de frente da fábrica, agora um pouco mais recuada, apresenta os sinais da rua após as batalhas entre policiais armados e grevistas desarmados. Fumaça das bombas de efeito moral sobem, destacando-se ao fundo a silhueta dos policiais e dos camburões. Restos de bandeiras, roupas e sapatos podem ser vagamente identificados nesta cena curta que tem uma carga simbólica considerável. No interior da fábrica esvaziada, Tião e Gesuíno trabalham quando o encarregado aparece e comunica um telefonema urgente. Tião sai pelo portão principal da fábrica e é perseguido pelos por operários que o chamam de "dedo-duro". Tião é espancado, até que Bráulio e outros operários aparecem para chamar os "extremistas" à moderação, que é a tônica da abordagem proveniente do personagem Otávio e da perspectiva política adotada pela parcela do movimento operário representada por ele. Bráulio dispersa a confusão envolvendo Tião, e em sua fala registramos "Ele não é o nosso inimigo! O nosso inimigo é quem explora a gente! O nosso inimigo é a repressão que arrebenta com a gente!" e rechaça qualquer espécie de "arruaça” por parte dos operários em nome da organização e do movimento ordeiro. Bráulio representa na diegese do filme a resistência de grupos católicos contra a ditadura militar. ${ }^{33}$

\footnotetext{
${ }^{32}$ SANTANA, Marco Aurélio e ANTUNES, Ricardo. “O PCB, os trabalhadores e o sindicalismo”. In: História do Marxismo no Brasil - Partidos e Movimentos após os anos 1960. Campinas, SP, editora da Unicamp, 2007.

${ }^{33}$ Idem. (p.382) “(...) A partir de 1970, em termos políticos mais gerais, enquanto parte da esquerda ainda se mantinha na luta armada, o PCB intensificou a política de constituição da frente democrática, consolidando seu apoio ao MDB e utilizando-se de sua legenda como alternativa política, já que o PCB continuava na ilegalidade." O personagem Bráulio discursa dentro da lógica da Frente Única, de caráter democrático, formando um contraponto com Otávio que é caracterizado como remanescente do PCB, e ambos formam, essa "frente democrática" de resistência à ditadura militar como alternativa ao radicalismo de Sartini que encarna essas oposições sindicais que pregavam o enfrentamento com a polícia.
} 
BLOCO 6: Rupturas

Maria chega ao quarto escoltada por suas companheiras, sendo recebida e acomodada por Romana. Esta ao saber que Otávio está preso no DOPS, decide ir liberálo das garras daquela instituição, que anos antes na trama da narrativa, já havia encarcerado seu marido. Tião sobe a rua correndo e entra em casa sendo interceptado por Terezinha, designada por Romana para manter o funcionamento da casa em ordem até o seu retorno. Tião chega ao quarto de seus pais, que é onde Maria estava aconchegada, abre a porta. Na cama estavam Maria e Silene adormecidas. Há uma discussão mais ríspida entre Tião e Silene. Maria repreende o namorado.

Chegamos ao primeiro acerto de contas de Tião que se dá com Maria. Resumidamente, Maria fala sobre o erro de Tião ao furar a greve, porque resultou em trair a confiança das pessoas que mais o amavam, colocando a atitude de Tião como uma traição aos "companheiros". Ela mesma, a família dele, seriam os "companheiros" junto com os outros anônimos companheiros de trabalho. O que mais chama atenção nessa discussão entre Maria e Tião está numa diferença de categorias de discurso sobre a realidade em que se encontram. A Maria do filme transcende a posição assumida pela Maria da peça em defesa da dignidade de uma "coletividade" muito maior do que a "comunidade" ou favela, que na peça tem conotações mais modestas. Ela fala claramente dos grandes movimentos de massas que agitaram a sociedade brasileira nos finais dos anos 1970. Sua fala não transparece tanto uma dimensão metafórica, quanto uma dimensão extremamente realista com o período de produção do filme. Segundo depoimentos dos atores de Eles não usam blacktie, sobretudo Carlos Alberto Ricceli e Bete Mendes, a Maria do filme quase que incorpora a militância de Bete Mendes. 
Digressões à parte, a estrutura básica desse bloco de desenlaces é o fracasso da estratégia de Tião. Em relação a Maria, é preciso que ele absorva o ressentimento e "corrija" o comportamento. Para ele, é questão de tempo, recuperar a confiança da mulher, que está emocionalmente abalada pelos acontecimentos recentes. Fica uma perspectiva de que o desenlace é negativo e o rompimento do noivado vai demorar para cicatrizar. Mas, Maria realiza conforme a própria estrutura do filme, uma pedagogia pela emoção. Os próximos planos apresentam outra perda: a saída da casa dos pais. Há uma leitura possível que aponta para um rito de passagem da "infância" do personagem para uma fase adulta em contato com a realidade. Nas suas provações, Tião chora e as lágrimas purificam. Tião se conforta com a mãe que o sustenta da queda, ouvindo e acreditando que o filho pode consertar tudo. Abre-se nessa cena entre mãe e filho novas esperanças de reconciliação. O fluxo de imagens percorre pelas formas poéticas do drama e do melodrama, correspondendo ao princípio que estrutura o filme em torno da função pedagógica da linguagem cinematográfica.

Na confrontação tensa com o pai, Tião permanece visualmente numa posição inferior. Otávio se dirige para Tião parando alguns degraus acima na escada que leva ao quintal, para falar com o filho como se falasse com um estranho. Tião permanece um tempo agachado e depois, se levanta e sustenta diante do pai a sua convicção de furar a greve. Otávio se enfurece e expulsa o filho de casa. Nesse bloco 6, a intensidade do jogo das concepções do filme político e do cinema comercial se entrelaçam e por isso, consideramos que as três sequências finais do filme correspondem ao desvendamento teórico do seu princípio estrutural ou formal. 
BLOCO 7: Velório de Bráulio, cena dos feijões e passeata-cortejo

Nesse último bloco, que corresponde aos 12 minutos finais do filme, vivenciamos o retorno de Sartini e Bráulio ao portão da fábrica. Sartini quer o confronto com as forças da repressão e Bráulio está ali para dissuadi-lo. A função pedagógica é forte aqui, com o apadrinhamento do operário mais impulsivo pelo militante sindical mais experiente. Com Bráulio e, também, com Otávio, funciona a pedagogia pela razão ou pela persuasão. Tentaremos dissertar com mais propriedade a respeito deste tópico em nossa análise propriamente dita. Em linhas gerais, o policiamento ao redor da fábrica havia aumentado. Mais uma vez, a onipresença das forças da repressão se fazem sentir. Desde a cena inicial no bar do Alípio, com a presença física de policiais fazendo rondas e prisões, passando pelo assassinato do jovem negro no mesmo bar, incorporando a gerência da fábrica com sua estratégia de cooptar os operários pela chantagem, até a repressão dos grevistas nas sequências finais do filme, há uma forte pressão pesando no ambiente social dos operários.

Vamos à cena em que Sartini se impacienta e arrasta os companheiros pela rua em direção ao portão da fábrica, formando um cordão humano. Um policial atira para o alto, assustando os operários. No meio da confusão, um policial à paisana atira em Bráulio, que tomba próximo aos companheiros aturdidos. É bom ressaltar, que o assassinato de Bráulio é uma representação do assassinato de Santo Dias, operário morto pela PM em uma manifestação de greve no início dos anos 1980. Trata-se de registro documental da participação de militantes ligados à igreja católica e da configuração da tragédia que retrata a repressão no período da ditadura militar no Brasil, e que entram na atualização do personagem Bráulio em relação à peça teatral. 
Num pequeno corte, acompanhamos Tião em sua retirada, solitário, triste, visivelmente abalado pela sucessão de acontecimentos desencadeados por sua escolha. Forma-se um contraponto com o início do filme, quando Tião e Maria estão no ônibus, numa perspectiva claramente romantizada. A saída de Tião, sentado no banco do ônibus, com o acompanhamento musical melancólico acaba por conferir ao personagem uma emoção um tanto contida. Outro pequeno corte na filmagem e estamos no velório de Bráulio num close geral do ambiente lotado, caixão ao centro, o padre num púlpito no canto esquerdo da tela, orações e choros de despedida. Quando comparamos com a cena anterior da partida solitária de Tião, percebemos que algo está sendo preparado para ser dito nestas sequências finais. A montagem conseguiu criar um efeito em que a própria música tema várias vezes acompanha as desventuras de Tião. Mas isso ocorre de maneira branda, quase despercebida, para ao final reforçar a contraposição da imagem de Tião com a imagem dos operários de braços dados na passeata cortejo em que a música irrompe mais vibrante, destacando a força da "coletividade".

Há um movimento perceptível de mudança de ritmos entrelaçando o melodrama, a tragédia e o épico produzindo uma "certa tensão" entre formas. A cena intermediária entre as duas cenas descritas acima, é o que chamamos de "cena dos feijões". É uma cena em que contracenam apenas Otávio e Romana, sentados na mesa de jantar escolhendo feijões. Não há trilha sonora, os atores não dialogam, sendo toda a comunicação dominada pela expressividade de olhares e gestos. Por isso, inicio a análise mais detalhada do filme pela cena dos feijões.

A partir da cena dos feijões, mas não apenas nesta, em todas sequências que preparam o epílogo do filme, encaminharemos a análise para a maneira como as formas produziram significados que tornam a linguagem cinematográfica, mais do que documento histórico, uma reflexão sobre a experiência histórica. 


\subsection{Cena dos feijões:}

Estamos no que consideramos como sendo o bloco 7 da análise, onde se encadeiam as cenas de três sequências que apresentam continuidade em termos de narrativa, mas que possuem, ao mesmo tempo, singularidades enquanto trechos com significados distintos. Vamos descrever e tentar decifrar alguns possíveis significados da cena dos feijões como episódio singular no filme e como a cena se encaixa nessas sequências finais. Leon Hirszman em depoimento afirmou que estava fazendo uma homenagem aos fundadores do cinema russo. A intenção do cineasta parece apontar, portanto, para um corte de sentido na continuidade do melodrama, introduzindo uma cena com outras características de composição. Se na expressão de Leon Hirszman, cinema russo for equivalente a um tipo de linguagem de entonação épica, poderíamos partir do principio de que há simbolismo nesta cena, querendo significar mais do que nos é oferecido na representação. Na própria cena e para o conjunto do filme, tentaremos percorrer por essas implicações teóricas.

Antes de procurarmos entender os efeitos das imagens no encadeamento do enredo, vamos descrever a composição do quadro formado pela cena dos feijões. Consideramos todos esses planos constituintes da mesma sequência, no bloco 7 formando uma segunda sequência após o assassinato de Bráulio. São 18 planos nessa sequência que constitui a cena dos feijões.

No plano 1 começa a sequência anunciada, com planos um pouco longos, silenciosos e expressivos. O plano 1 abre-se com um quadro em que percebemos Otávio na posição frontal, com as duas mãos postas sobre a mesa. Conseguimos identificar todos os objetos presentes na cena. Próximo à mão esquerda de Otávio, há um copo e uma garrafa de cachaça. À frente dos copos, há uma bacia de alumínio para escolher os 
feijões. Um pouco mais à frente, mais ao centro da mesa, um recipiente fechado onde os feijões estão guardados. À direita de Otávio, Romana coloca a mão sobre a mão direita de Otávio. Com a outra mão, Romana contém o choro na boca. A expressão de ambos é extremamente pesarosa. Ao fundo, vislumbramos o papel de parede gasto e sujo devido ao uso. Em termos socioeconômicos, há uma tipificação da pobreza do casal de protagonistas, como aliás é recorrente em todo o filme. Nenhuma música de fundo, nenhum diálogo. Uma cena absolutamente silenciosa. Otávio suspira e abre a garrafa, enchendo o seu copo. A composição do quadro permanece quase a mesma, com exceção deste gesto. Romana abaixa a mão que estava na boca, limpando a mesa para iniciar a tarefa prefigurada pela disposição dos objetos que já descrevemos. Otávio coloca as duas mãos sobre uma das mãos de Romana que permaneceu na mesa, confortando a companheira que olha para ele. As mãos se separam, Romana se dirige para o pote dos feijões, desrosqueando a tampa e Otávio volta-se para o copo de cachaça. Ambos realizam seus gestos quase macânicamente, demonstrando a mesma tristeza que apresentavam na breve inércia da cena inicial. Otávio ensaia um olhar para Romana, que despeja os primeiros feijões sobre a mesa. Romana repete o mesmo gesto por duas vezes ainda, quando na terceira vez, para de recolher os feijões e é dominada por suas próprias reflexões hesitando um pouco. Otávio toma cachaça e observa a hesitação da esposa. Romana derrama alguns feijões de volta para o recipiente. Otávio permanece observando a esposa e parece decifrar o que se passa no íntimo da companheira. Romana fecha o recipiente e olha para Otávio, iniciando uma troca de olhares bastante significativa.

O plano 2 foca na expressão triste de Otávio que bebe cachaça, ruminando seus pensamentos que agora passa a compartilhar com Romana. Otávio olha o copo, bebe o líquido, deposita o copo na mesa, olha para o teto por instantes, mas retoma o diálogo 
visual e silencioso com a esposa. O plano 3 foca em Romana que chora e olha para o marido, esboçando um sorriso difícil de acontecer. Ambos compartilham o mesmo sofrimento. No plano 4, Otávio retribui o olhar. O plano 5 foca na mão de Romana recolocando-se sobre a mão de Otávio na mesa. É um plano que sugere que ambos compartilham a mesma dor e se apoiam mutuamente. As mãos se apertam, demonstrando a dignidade que os anima a prosseguir. Passamos para o plano 6, Romana chora e seu olhar para Otávio é de esperança, mesmo depois de todo desespero experimentado. Novamente no plano 7, as mãos de Otávio seguram as de Romana, mas agora, são ambas as mãos e com mais ênfase no sentido de recobrar forças numa troca intensa de carinho. A mão de Romana retoma lentamente a tarefa de escolher os feijões, com um leve deslocamento da câmera.

O plano 8 enquadra Romana, agora mais aliviada, escolhendo feijões e derrubando-os na bacia que tem no colo. No plano 9, Otávio observa Romana demonstrando estar mais recomposto também. E, num gesto solidário, passa a escolher os feijões junto com a companheira. O plano 10 é uma continuidade do anterior, com os feijões caindo na bacia metálica. O plano 11 foca no rosto de Otávio, cujo olhar se direciona da bacia em que ouvimos cairem os feijões para o rosto da companheira. A imagem se sustenta no rosto comovido de Otávio, numa demonstração de aprendizado com a vivência cotidiana. No plano 12 novamente aparece a mão de Otávio entregando à Romana os feijões escolhidos por ele. E a mão de Romana recolhendo-os e jogando-os na bacia. Em toda essa cena, ouvimos os ruídos dos feijões caindo na bacia. O plano 13 apresenta Romana, com o rosto banhado em lágrimas, o que pressupõe um choro reconfortador com o gesto do marido. Romana enxuga as lágrimas, concentrando-se em sua tarefa. Plano 14, novamente, vemos somente as suas mãos na tarefa de escolher e 
derramar os grãos de feijão na bacia, agora num ritmo mais cadenciado. Acordes do violão ao fundo premeditando a cena seguinte. A música tema do filme vai crescendo de intensidade ao fundo. Assim encerra-se a cena dos feijões.

Nessa breve sequência, conduzida por Gianfrancesco Guarnieri e Fernanda Montenegro, há um movimento que desloca a perspectiva dos primeiros enquadramentos realizados na cena. Os primeiros enquadramentos da cena demonstram uma grande tensão nos rostos e quase não há nenhum gesto, como se fosse um quadro realmente. É a mudança gradativa das expressões que confere à cena o significado de uma mudança nos sentimentos dos personagens, em que podemos inferir que a partir da experiência cotidiana podemos renovar a decisão e iniciar um novo enfrentamento com a realidade. Essa perspectiva parece ganhar mais significado quando valorizamos a experiência que os sofrimentos propiciam, como se fosse um "aprendizado", em que o meio social não é apenas condicionamento. Isso porque relacionando a cena com o enredo do filme podemos atribuir um cunho social ao sofrimento experimentado por Romana e Otávio com a derrota da greve. Uma derrota que culminou com o assassinato de Bráulio e a "traição" de Tião. Um misto de frustrações provocadas pelo ressentimento pessoal, mas ampliadas pela repressão governamental que oprime os trabalhadores. A cena dos feijões é emblemática desta "ruptura" com as expectativas formadas em torno de duas opções de ação apresentadas pelo filme: a solução individual e a solução coletiva para a crise que representa um período marcado pelo arrocho salarial, pelas mobilizações grevistas, pelo custo de vida e pela repressão aos pobres. $\mathrm{Ou}$, mais precisamente, parece que todo o discurso individualista de Tião que fornece um ponto forte onde o drama vem se apoiando, cena após cena, até este desfecho, é confrontado definitivamente pela realidade das condições da vida operária. 
A cena dos feijões é conduzida de forma a produzir a empatia do espectador com a condição de vida dos operários. Ao mesmo tempo, pode provocar emoções ambíguas porque aproxima o espectador da realidade social brasileira, tomando o operário como símbolo da condição de vida explorada, e pretende assinalar que desta crise pode emergir um novo movimento popular mais fortalecido pelo sofrimento. É o que irrompe nas cenas do epílogo com a passeata misturada ao cortejo de Bráulio. Pode ainda representar que é preciso cautela com a euforia reivindicatória das greves, com os limites das conquistas ao preço de muitos sacrifícios por parte dos trabalhadores. Das pequenas vitórias graduais de todo processo reivindicatório de greve, os operários devem assimilar as derrotas e perdas inevitáveis. A ambiguidade fica por conta de que há uma sensação de que mesmo a opção coletiva parece insuficiente diante da atual configuração de forças com que lidam os protagonistas. De qualquer forma, a mudança na expressão dos rostos de Romana e Otávio e a erupção da massa operária em passeata, pode apontar para uma recomposição de forças populares, únicas capazes de resistir a governos autoritários e políticas econômicas restritivas, mesmo num horizonte de derrota. Como contraponto a esse diagnóstico acompanhamos a despedida de Tião solitário, partindo num ônibus, com expressão séria e triste, numa cena curtíssima, apontando, possivelmente, para a derrota da opção individual tentada por ele desde que decidiu resolver as coisas sozinho. É a tragédia de Tião, posta em comparação com a tragédia de Bráulio que acompanhamos um pouco antes. A cena dos feijões confere a Otávio papel exclusivo de destaque no drama, como protagonista da mudança pela via política e coletiva, imbuído de persistência e companheirismo. Ou ainda, podemos inferir que é levado pelas novas circunstâncias trágicas, a mudar seus pontos de vista pessoais em favor do coletivismo que ele tanto prezava. Enquanto Tião afunda na tragédia social, Otávio é alçado para outra experiência de solidariedade com os 
companheiros grevistas. É com essas imagens que as sequências finais constroem o epílogo do drama trágico da família de Otávio. A estrutura do drama nos mantém nessa percepção de drama pessoal dos operários em confronto com as forças repressivas da ditadura militar, um tanto maniqueísta.

Ainda nessa perspectiva, mesmo a opção coletiva corresponde a perdas difíceis e a precipitação da greve, criticada insistentemente por Otávio e Bráulio, impõe a premissa de que uma "greve ensinada no golpe" (fala de Bráulio sobre Sartini, outra corrente do movimento operário), talvez não valha a pena como instrumento de luta para a classe trabalhadora. Esse parece o didatismo que a cena confere aos acontecimentos narrados, como se a greve fosse um instrumento pedagógico para os próprios operários. A experiência do próprio Leon Hirszman que já viveu e refletiu sobre a história, confere ao desfecho do filme o tom melancólico da desilusão com as possibilidades de reorganizar a esquerda a partir do novo sindicalismo ou da radicalização das várias novas oposições ao $\mathrm{PCB}$, que se desenhavam no campo da esquerda.

O simbolismo dos feijões pode apontar para uma analogia de que os grãos "podres" devem ser separados dos grãos "aptos" para o ritual de preparo do alimento que mantém o corpo em funcionamento no cotidiano. Essas alusões ao estado físico dos feijões pode produzir uma outra metáfora que se constrói nos quatro primeiros blocos do filme, que antecedem a greve no bloco 5. A metáfora de que nos preparativos para a greve, atitudes são "selecionadas" pelos operários mais experientes, e portanto, mais aptos para ensinar como se faz uma greve. A seletividade de idéias e atitudes também compõem os diálogos entre Otávio e Tião e entre Otávio e os companheiros de trabalho, acerca da necessidade de se prepararem para manter a unidade do movimento operário e não apenas vencer na greve, com discussões e propostas que alimentariam o "corpo" da 
opção coletiva de mobilização. São metáforas sobre a possibilidade de se fazer escolhas, de selecionar entre os "bons" e os "imprestáveis", entre idéias, tendências, atitudes e comprometimentos.

Tião, Jesuíno e todos os que furaram a greve, representam a opção individual e não figuram na parte conclusiva do filme, foram “selecionados". Mesmo Sartini, sujeito de militância mais radicalizada, encarando a greve como instrumento de mobilização para a obtenção de resultados mais imediatos, rende-se à lógica que mais corresponde ao bem do corpo (coletividade) dos operários. O filme, no seu conjunto, tem dois polos bem definidos e antagônicos, representados em Otávio e Tião. Jesuíno e Sartini, não são exatamente personagens do drama, sendo muito mais personificações dos extremos em jogo na construção do enredo. Isso se deve ao recorte proposital do roteiro no tratamento dado à greve e aos posicionamentos políticos que, resumidamente, remetem a dois tipos de embates (um tanto marcados pela ambiguidade) entre Tião e Gesuíno de um lado e entre Otávio e Sartini, por outro. Há uma enorme dificuldade em se tratar da luta de classes pela moldura melodramática que o drama utiliza para isolar as "essências individuais dos protagonistas. De maneira que o problema surgido entre pai e filho parece apontar muito mais para uma solução pessoal, perdendo-se a dimensão social em jogo. Há uma outra cena, envolvendo Otávio, Sartini e Bráulio em que este último, clama aos companheiros que retornem ao ponto primordial da existência do movimento operário que é discutir "política". Ou seja, "não é questão pessoal, é política!" são as palavras exatas utilizadas por Bráulio. Mesmo sendo uma cena anterior, de uma sequência que precede àquela em que Tião fura a greve e que estávamos discutindo, não interfere nessa interface entre os dois discursos contraditórios de uma perspectiva que reconhece a luta de classes e outra que defende o individualismo. A estrutura dramática em movimento em Eles não usam blacktie, ou seria mais mérito da montagem, 
“autonomizou" os destinos de Otávio e Tião, tornando-se realmente possível encará-los como paralelos ou independentes.

Para Iná Camargo Costa, em sua obra A hora do teatro épico no Brasil ${ }^{34}$, em que analisa a peça teatral Eles não usam blacktie (1958) de Gianfrancesco Guarnieri, há uma contradição entre forma e conteúdo. A forma é mais "conservadora", representando o ponto de vista de Tião, sendo o veículo melodramático insuficiente, para um assunto que é mais "progressista", a greve, que é muito maior do que a forma que pretende abrangê-lo. Não há uma plena realização dos recursos poéticos próprios ao gênero épico na estrutura dramática da peça. O assunto "épico" da peça, está melhor representado em Otávio, militante do $\mathrm{PCB}$, stalinista convicto, que criaria uma oposição radical em termos políticos em comparação com a alienação do filho fura-greve. Na atualização da peça teatral para o cinema, Leon Hirszman e Gianfrancesco Guarnieri procuraram, segundo seus próprios depoimentos, eliminar o maniqueísmo original entre engajamento político e alienação que encontra-se ressaltado na análise de Iná Camargo Costa. A contradição entre forma e conteúdo, analisada desta maneira, representaria uma "tensão" ideológica em que a arte produzida pelas classes trabalhadoras ou por artistas vinculados às demandas dessas classes, permaneceria contaminada pelo pensamento conservador das classes dominantes. Consideramos bastante sugestiva esta análise, mas no processo de transposição entre as linguagens teatral e cinematográfica, há uma nova dinâmica entre forma e conteúdo que corresponde à maneira como o cineasta organizou os dois discursos no seu filme. Outra análise importante para os

\footnotetext{
34 “(...) Começando pelo assunto que deveria ter encontrado a forma adequada, Eles não usam blacktie conta a história de uma família de trabalhadores favelados e suas cercanias às voltas com um problema crucial: uma greve. Como sabem os estudiosos da obra de Brecht, greve não é um assunto de ordem dramática, pois dificilmente os recursos oferecidos pelo diálogo dramático - o instrumento por excelência do drama - alcançam a sua amplitude. Recorrendo ao repertório da velha lógica formal, poderíamos dizer que a extensão (o tamanho) desse assunto é maior que o veículo (o diálogo dramático). (...) A verdade de Eles não usam blacktie reside justamente na contradição entre forma (conservadora) e conteúdo (progressista). (p.24 e p.39, respectivamente).
} 
nossos propósitos, é a leitura do "teor político da peça” feita por Maurício Segall em um artigo que consta no seu livro Controvérsias e Dissonâncias. ${ }^{35} \mathrm{O}$ autor disseca o conteúdo político do filme Eles não usam blacktie, problematizando sobre o alinhamento dos roteiristas com a Unidade Sindical, conjunto de forças conciliatórias de pelegos em detrimento dos movimentos operários mais progressistas. Em certo sentido, parece que a análise de Segall reforça a análise de Iná Camargo, porque apresenta a contradição entre o que realmente acontecia no $\mathrm{ABC}$ Paulista naquele período e o tratamento modesto destes temas no filme. Apenas Maurício Segall não se refere a uma contradição entre forma e conteúdo, direcionando sua análise para as ambiguidades do discurso político do filme que trata da greve derrotada de 1979, levantando indagações acerca das escolhas políticas de Leon Hirszman e Guarnieri. O que chama a atenção é a referência do autor a uma tentativa de "ensinar" política e moral para os operários e dos prováveis efeitos dessa "pedagogia" sobre os espectadores. O mesmo incômodo que Iná Camargo Costa revelou em relação à peça teatral, parece ter levado Maurício Segall a criticar o filme, mesmo que os pressupostos teóricos de ambos sejam diferentes.

A cena dos feijões é marcada pela emoção. Não há trilha sonora induzindo um ambiente sentimental. Não há diálogo conduzindo para a autoexplicação da cena. O que há é um direcionamento do nosso olhar para uma mudança de sentimentos, percebida pelas expressões faciais e gestos dos atores. E existe pelo menos uma razão para afirmar que a cena, quando considerada em seus detalhes, reproduz a mesma estrutura do conjunto do filme: há um aprendizado em andamento. Os olhares trocados pelo experiente casal vão se modificando do sofrimento estático para um esboço de sorriso, e para as mãos solidárias do marido que ajuda a companheira na tarefa de escolher os

\footnotetext{
35 “(...) Para chegar a isso, a fita não adaptou a peça. Atualizou-a, com a pretensão indiscutível de dar uma aula política e moral a certos setores do movimento operário. Acaba assim, nem que seja por coincidência, propagandeando, justificando e defendendo 'subliminarmente' a linha política daquelas forças conciliatórias aliadas aos pelegos, que se aglutinam na Unidade Sindical, sobretudo no que se refere ao 'fortalecimento' da estrutura sindical que aí está." (p.307)
} 
feijões. Romana enxuga as lágrimas, demonstrando que é necessário se restabelecer e continuar em frente. Otávio também se recompõe, entende e participa do mesmo sentimento de sua companheira de tantas lutas. O princípio formal que organiza o filme em cada uma de suas partes e no todo, se compõe com esses dois elementos presentes fortemente na cena dos feijões: uma pedagogia da emoção. Formulando melhor, poderíamos considerar que há uma certa pedagogia que se utiliza das emoções, para inserir o cotidiano na política, ou o inverso, a política no cotidiano criando o cimento que faltava na separação rígida entre os discursos de Otávio e Tião, próprios da estrutura dramática que analisamos. A cena dos feijões é o coroamento da opção coletivista de Otávio, mas ao mesmo tempo, marca uma pequena transição na estrutura dramática que polarizava o filme até este ponto, direcionando o olhar para o aprendizado com a própria experiência participativa e popular a despeito das convicções pessoais. Há uma mudança de enfoque da rigidez da estrutura formal dramática para o conteúdo de feições múltiplas da épica. ${ }^{36}$

O aprendizado é por vezes doloroso, mas sempre ocorre quando há sutil passagem do universo pessoal para uma dimensão coletiva. Otávio e Bráulio aprenderam a necessidade de organização dos trabalhadores e não apenas mobilizações para reajustes salariais, Maria e Silene aprendem a ser solidárias participando da greve, Romana permanece firme ao lado do marido, indo a delegacia interceder por sua liberdade, e Tião em sua retirada, solitário e pensativo no ônibus após todos os

\footnotetext{
${ }^{36}$ “(...) De causa em causa, sobe-se à última, incondicionada, que não é efeito de outra causa. Ao longo de toda a série, a estrita necessidade que une os elos permite indagar o porque do vínculo, a razão pelo qual algo ocorre. Somente essa causa última, dá uma resposta incontrastável à pergunta pelo motivo. Como centro de que parte toda a cadeia dedutiva do drama, estruturado assim numa composição espiralada, uma tal causa foi batizada por Lucáks ( na falta de melhor termo) com o nome de "visão de mundo". Contra ela cabem apenas objeções que versem sobre a forma, ou melhor, se a visão de mundo for bem lograda, se ela, como centro, conciliar os elementos com minúcia, alinhavando-os sob o signo da necessidade, seu próprio conteúdo dilui-se na forma, tornando supérflua a questão do motivo da causa última, pois a resposta já é a forma estruturada do drama.(p.202). Posfácio de José Carlos Mariani de Macedo, In: LUCAKS, Georg. A Teoria do Romance, São Paulo, Duas Cidades Editora 34, 2000.
} 
acontecimentos que mudaram a sua vida, também parece, pelo menos, ter que reconsiderar sua linha de ação. Até mesmo Sartini parece arrependido, no velório de Bráulio, demonstrando a derrota e também uma possibilidade de reconsiderar a sua linha de atuação.

Ainda em termos de enredo, a cena dos feijões ganha em intensidade quando retomamos as sequências anterior e posterior, respectivamente, de 18 planos durante manifestação na porta da fábrica. Há um plano encaixado nessa sequência do assassinato de Bráulio, onde acompanhamos a despedida solitária de Tião. Após a despedida de Tião são mais cinco planos que correspondem ao velório de Bráulio. A cena dos feijões seria, portanto, efeito dos dois acontecimentos anteriores: assassinato de Bráulio e partida de Tião. Repetindo a lógica formal que organiza a cena dos feijões, a última sequência que vai do plano 14 ao plano 20 , seria o momento de "duro aprendizado" e renovação da esperança, apresentando o cortejo de Bráulio com os trabalhadores de mãos dadas, aos gritos de que a greve continua. Nessa última sequência, a música tema rivaliza com os ruídos externos, os letreiros surgem na tela e os figurantes são anônimos convidados pela equipe de filmagem, representando a massa operária em luto e passeata ao mesmo tempo. O próprio filme que se encaminha, em termos de enredo, para o epílogo que são essas breves sequências finais, apresenta o mesmo movimento que preparara, ao longo de todas as sequências anteriores, para um "aprendizado" das condições socioeconômicas do trabalhador brasileiro e uma empatia com a causa operária através da emoção. A emoção é a estratégia do filme para uma maior comunicação com o público. Ao afirmarmos que o filme apresenta uma pedagogia da emoção, consideramos em parte que o filme foi montado tendo essa questão da conscientização do público como eixo central. Por isso, consideramos o maniqueísmo original entre engajamento político e alienação, como subordinado ao 
princípio pedagógico estruturador do filme. Não apenas a greve funcionaria como instrumento pedagógico, como o próprio filme foi pensado com esse propósito. Esse é um ponto que precisamos abordar com mais cuidado, sobretudo, quando nos detivermos sobre os diálogos entre pai e filho e os detalhes destas cenas em que ambos contracenam os seus antagonismos. Ao todo são três ocasiões em que Otávio e Tião dialogam ou discutem ao longo da narrativa. Por enquanto, permaneceremos um pouco mais em considerações sobre a forma da narração e os detalhes da cena dos feijões, que correspondem ao propósito desta parte da análise.

No filme, pensamos que opera como princípio formal uma "pedagogia" que utiliza a emoção como estratégia de comunicação com o público, mas que tem compromisso com uma concepção muito específica do movimento operário que é representado por Otávio. Este é o personagem mais politizado do filme, e ele é o próprio princípio pedagógico em ação. Em todas as sequências em que ele aparece, ele é o portador de uma intenção pedagógica, seja na família ou entre os companheiros operários. De maneira que o filme valoriza a comunicação com o publico com um determinado propósito. $\mathrm{O}$ entretenimento é encarado como elemento secundário ou subordinado ao objetivo de "formação" do sujeito, mesmo que o filme em si, careça de uma proposta bem elaborada em termos políticos e ideológicos.

Ao mesmo tempo, possui inerente uma crítica ao individualismo representado por Tião, e mais ainda, por Gesuíno. O posicionamento de Sartini é rejeitado, mas ele é solidário com os companheiros grevistas. O maniqueísmo político-ideológico é substituído por uma pedagogia que, pretende, entre outras coisas, suscitar a reflexão diante da atitude consciente de Tião em furar a greve. O ápice da estratégia pedagógica do filme encontra-se certamente nas sequências em que Tião fura a greve e precisa acertar contas com a namorada e o pai. Antes de iniciarmos a análise destas sequências 
específicas do filme, vamos tratar alguns aspectos sobre a singularidade destas três sequências finais.

O que pode significar a cena dos feijões em termos mais estritamente estéticos? A cena dos feijões não parece apenas complementar o enredo nem tampouco um mero apêndice no corpo da narrativa. A cena dos feijões como pretendemos demonstrar até aqui tem um papel crucial na forma da narração do filme, e estrutura-se de acordo com a lógica do princípio formal da pedagogia da emoção. Mas, a cena dos feijões pode ser caracterizada como possuidora de uma categoria diferente do restante do filme. Ou seja, na maioria dos planos do filme prevalecem as mesmas regras básicas de composição do drama convencional, com diálogos e ocasionalmente música de estúdio. ${ }^{37}$ Retomando um comentário anterior acerca da estratégia de comunicação com o público, o melodrama como forma de teatro popular que encontrou importante acolhida nos meios cinematográficos, tornando-se uma forma canônica, sobretudo, no naturalismo hollywoodiano, não é adotado literalmente no filme que analisamos. Parece-nos que aqui reside a maior tensão apresentada pelo filme. Drama, melodrama e realismo crítico negociam estratégias de comunicação com o público. O que faz com que o filme transite entre gêneros diferentes, com um estilo de cinema mais realista e mais engajado do que geralmente acontece nas produções nacionais. O melodrama sempre foi utilizado nas mais diferentes concepções e em diversas linguagens como teatro, televisão e cinema, possuindo, também por isso, uma enorme flexibilidade. Os mais diversos argumentos podem ser utilizados para sua justificação. Nesse sentido, o filme Eles não usam blacktie não se prende a um conjunto normativo de regras da forma cinematográfica, mas transita por algumas referências do gênero melodrama como nas intrigas fomentadas por Gesuíno e com as quais Tião compactua na delação aos operários

\footnotetext{
${ }^{37}$ THOMASSEAU, Jean-marie. O melodrama. São Paulo, Perspectiva, 2005.
} 
grevistas. Esse "complô" arquitetado por Gesuíno parece bem ao gosto melodramático, sobretudo daquele presente em telenovelas, conferindo certa artificialidade e uma quase teoria da conspiração que enfraquece a perspectiva da luta de classes entre operários e patrões. Um certo encaminhamento sentimental dado ao relacionamento entre Tião e Maria que poderia conduzir ao lugar comum do amor que vence todas as barreiras. E o conflito entre Otávio e Tião que possui nuances de um conflito de gerações. Entre Otávio e Tião há toda uma questão ideológica e política, mas podemos vislumbrar certos deslizes que apontam para diferenças sentimentais entre ambos. Otávio teria sido militante desde sempre, preso e perseguido pela polícia. Tião havia crescido com os padrinhos que o "transformaram" num jovem com aspirações consumistas de classe média, contraditório com o meio social popular e operário em que agora vive.

Se considerada do ponto de vista das tramas do enredo ou do próprio desenrolar das ações narradas de forma linear, a cena dos feijões poderia ser classificada como mero apêndice que não prejudicaria em nada o entendimento daquilo que se pretende narrar. Mas é uma cena que, por sua vez, ressalta uma característica que é singular em relação a outras partes do filme. Há uma mudança de tratamento da cena, tornando a ação mais complexa, como se fosse proposta uma pequena pausa em meio ao desenrolar da narrativa principal do filme. Uma espécie de pausa capaz de provocar reflexão, como se a cena não tivesse sido concebida apenas para emocionar. Dentro do estilo de montagem adotado pelo cineasta, a cena dos feijões confere uma abertura para a reflexão acerca do entendimento acerca da condição social do operário, uma conotação mais épica ${ }^{38}$. A dor de Otávio e Romana assume uma dimensão solidária com a dor dos companheiros, com a dor pela morte de Bráulio, com a decepção provocada por Tião, com a condição de vida do proletariado brasileiro.

\footnotetext{
${ }^{38}$ SZONDI, Peter. Teoria da drama moderno (1880-1950). São Paulo, Cosac\&Naify, 2001.
} 
A possibilidade de fazer um "balanço" de tudo o que foi representado no filme, sobretudo em relação aos efeitos da greve na vida cotidiana dos operários representados no casal que contracena, introduz um fragmento de pensamento crítico. Mas esse fragmento de pensamento crítico é bem restrito, circunscrevendo-se a um lampejo de consciência política. A cena estabelece um processo de valorização da consciência política que engloba todos os dramas da existência dos protagonistas que precisam recolher os cacos e continuar no seu papel de apoiar o movimento coletivo que transcende em importância a mera cicatrização de dores pessoais.

Dessa maneira, reforçamos que a cena dos feijões possui uma forte conotação pedagógica com o propósito de desfazer perante o espectador a ilusão da mera encenação naturalista de um conflito doméstico que poderia conduzir-se para um desfecho intimista sem maiores consequências. Mas isso não significa que apenas nesta cena se opera o corte decisivo com o restante do filme. Em todo o filme, desde a primeira cena há essas sobreposições de modos de expressão com diferentes nuances, quando Tião e Maria retornam numa noite chuvosa, de um sábado que haviam aproveitado indo a o cinema, e se deparam com uma batida policial no bar do Alípio.

Por isso, a tensão entre forma e conteúdo está no descompasso entre os modos de expressão diferentes adotados, conforme os ângulos escolhidos, a ênfase em certos detalhes, e o ocultamento de certos aspectos que tornariam muito mais óbvia numa apreensão imediata, por exemplo, da luta de classes. Porque tratar cinematograficamente de greve, de operários, de cotidiano da periferia mesmo que matizada pela ênfase na "questão operária", e, portanto, de uma maneira específica de retratar o cotidiano pelo viés da família operária, sugere que independentemente da opção ideológica do cineasta, a luta de classes é um tópico necessário. 
A caracterização do bar do Alípio (lazer), da fábrica (trabalho), do interior da casa onde vive o operário, a vizinhança do bairro operário, a violência urbana, em suma, todo o pano de fundo que confere sentido ao drama operário encenado, são apresentados com fortes traços populares. Por isso, a perspectiva do filme, mantém-se popular, valorizando a greve como instrumento pedagógico de luta dos trabalhadores, do ponto de vista prático. Ao mesmo tempo, o filme problematiza com a greve e com essa função de instrumento pedagógico, porque Tião não aprendeu nada a partir de outras greves.

Otávio e Bráulio extrapolam na sua condição de personagens melodramáticos, numa relação dialética com a experiência da militância desde os tempos de Arena, de CPC, de PCB. “(...) A atuação do PCB, no ciclo grevista vivenciado pelo ABC paulista, especialmente nos embates de 1979 e 1980, em seu sentido mais profundo, visava evitar a eclosão das greves (...)”, de acordo com Marco Aurélio Santana e Ricardo Antunes, percebemos algo marcante na atuação de Otávio e Bráulio no filme, tentando conter o impetuoso Sartini.

Mais especificamente talvez, a toda geração de comunistas ligados ao PCB que comungou na militância estética e política por um teatro e um cinema que expressassem a realidade social brasileira, se ressentissem de que era necessário, sobretudo aos mais jovens que não viveram aquela "experiência", como Tião, aprendessem algo sobre a greve e sobre a vida.

Citando novamente Marco Aurélio Santana e Ricardo Antunes, para contextualizar nossa última afirmação:

“(...) Em 1978, o cenário político nacional foi sacudido pela greve dos metalúrgicos do ABC paulista. A posição do PCB acerca dessa greve e de outros movimentos que se espalharam pelo país desdobrou-se no plano sindical e no plano político geral. No plano sindical, a perspectiva comunista era uma análise positiva da 
greve, devendo-se evitar, contudo, o triunfalismo, evitando-se cair nos erros do passado. Acerca do plano político mais geral, a política comunista pode ser aferida na declaração do Comitê Central do PCB sobre o movimento sindical (...)”(p.383) 
CAPÍTULO 3 - OTÁVIO E TIÃO: ou tensão entre forma e conteúdo

\subsection{Maniqueísmo aparente}

Considerando a cena dos feijões hipotética demais como exemplo da pedagogia da emoção, vamos analisar com mais detalhes o que denominamos de bloco 3, a semana que antecede a greve. Curiosamente, é a única sequência em que o dia se desenrola desde a manhã até o anoitecer, do ambiente da fábrica ao jantar em família, em toda a narrativa. A sequência incia-se com Romana servindo a sopa para todos, já reunidos à mesa de jantar, aguardando pela refeição. Toda a complexidade do contexto social e político, recuperado pelas agitações que vinham do $\mathrm{ABC}$ paulista, é transposto para o ambiente doméstico. E se Otávio e Bráulio representam fortemente as posições do PCB de que as conquistas obtidas pelas mobilizações históricas dos trabalhadores, em cuja liderança sobre uma base policlassista poderiam perder-se diante do confronto aberto, proveniente de outra base, de caráter mais autônomo, que desconsiderava a moderação como estratégia política, é Romana que assume esse papel no âmbito doméstico. No ambiente da fábrica, Sartini simboliza a "nova esquerda", cujo ímpeto e radicalização pode ser também associado ao método de ação do Novo Sindicalismo que lutava por reajustes salariais e contra as lideranças pelegas, associadas ao $\mathrm{PCB}$, que resultaria na fundação do PT, e daí o seu comportamento sempre crítico em relação ao posicionamento de Otávio e Bráulio. No é ambiente doméstico, com muitas ressalvas, Tião não seria como aparentava ser no ambiente da fábrica. Ou seja, Tião poderia ser atraído para a órbita daquela base policlassista, discutida linhas atrás, pois, em várias oportunidades demonstrara não ser inteiramente alienado. Quando comparamos Gesuíno com Tião, a diferença é óbvia. Quando colocamos Tião em julgamento após a 
cena em que ele fura a greve, traindo a confiança do pai e dos outros operários, o status dele muda completamente, arremessando-o na posição de reacionário convicto. No terreno político, não há meio termo, e parece não haver mediadores, apontando para a radicalização daquele momento, e perda de controle do PCB do movimento grevista. No âmbito familiar, Romana exerce esse papel de mediadora dos extremismos sejam de esquerda por parte do pai, ou mais à direita, por parte de Tião.

Vamos atentar agora para o foco narrativo, ou como o drama se intensifica, polarizando com as representações do pai e do filho. Um desdobramento da pedagogia da emoção, está nos micro-conflitos que investem o par central Otávio e Tião de características opostas que vão se intensificando conforme a greve se aproxima, mas diminuindo bastante a carga de radicalização que poderia caracterizar-se como mera reprodução da forma canônica do maniqueísmo, típico do modelo estabelecido na maior indústria cultural do mundo.

A narrativa segue pontuando os contrastes entre pai e filho, alternando cenas entre as duas perspectivas de ação. Na peça teatral Eles não usam blacktie, a narrativa adotava a perspectiva de Tião pela forma dramática ${ }^{39}$ e Otávio representava o ponto de vista do conteúdo que é revolucionário, segundo o crítico Décio de Almeida Prado.

\footnotetext{
${ }^{39}$ PRADO, Décio de Ameida. Teatro em progresso (pp.132-134). In: GUARNIERI, Gianfrancesco. Eles não usam blacktie, São Paulo, Civilização Brasileira, 8‥ Edição, 2000. “(...) A ação, pois, pelo seu lado moral, prolonga-se além dos dados originais do problema, transcendendo de muito o caso local da greve. (...) Para ele, greve, 'revolução' são palavras longínquas e problemáticas promessas de um futuro melhor. A realidade imediata é a mulher, o filho, a fome, a miséria, à qual é preciso fugir a todo o custo. E uma sociedade que se fundamenta sobre o individualismo, como a nossa, não está em condições de exigir sacrifício de quem quer que seja. (...) Certo que o ponto de vista revolucionário, representado pelo pai, teria bons argumentos a estas considerações. Mas a perspectiva da peça é a do filho: o drama é seu, ele é quem deverá pronunciar-se perante a existência concreta da greve. Sua posição, no fundo, não diverge muito da de qualquer rapaz de vinte anos chamado a decidir pela primeira vez entre suas conveniências pessoais e certos apelos de outra natureza, menos egoístas e mais generosos. (...) Não é preciso, portanto, ser operário, ter participado da preparação de uma greve, para sentir o impacto das questões propostas com tanta emoção pela peça. $O$ segredo de Eles não usam blacktie é dizer respeito a todos nós, é ter alguma coisa a segredar à consciência de cada espectador. (...) para sentir que é esse o verdadeiro problema, veja-se como a própria gradação psicológica das personagens repete o choque entre o que é e o que deveria ser, indo do otimismo algo sonhador e ingênuo do pai, sempre pronto a creditar na perfeição moral da humanidade, até o realismo sem ilusões da mãe.(pp.14-15)
} 
Acreditamos que no filme, houve uma modificação nesta estrutura dramática básica, e não há a mesma diferença conceitual entre os protagonistas que parece mais ressaltada na peça teatral, até porque não havia uma fragmentação tão profunda na esquerda e o PCB era o principal partido da classe operária, mas há uma diferença no modo como os elementos dramáticos estão articulados por um estilo de montagem, que consideramos específico, dentro da perspectiva do cinema de autor.

Mas de qualquer maneira, existe uma tentativa de "reduzir" essa diferença original entre os personagens Otávio e Tião, optando por uma simetria que se sustenta, intensificando o suspense, até o momento em que Tião fura a greve. Essa estratégia adotada pelos co-autores ${ }^{40}$ do enredo, ressalta uma preocupação em não demarcar certas posições políticas dos protagonistas muito fixamente, o que se caracteriza como um recurso recorrente em várias partes do filme. ${ }^{41}$ Com isso, ganha-se em intensidade dramática, mas perde-se em profundidade. Ressalta-se a essência das ações dramáticas dos personagens, mas perde-se inevitavelmente na plasticidade das cenas.

Tião é um personagem que inicia o filme demonstrando preocupação com a gravidez da namorada, mas quando chega a greve e estoura a repressão policial na porta da fábrica, mesmo sabendo que Maria iria participar dos piquetes, ele cuida apenas de

\footnotetext{
${ }^{40}$ Em entrevista, o cineasta Leon Hirszman afirmou o seguinte sobre o processo de atualização da peça Eles não usam blacktie para o cinema: “(...) A adaptação da peça para o cinema resultou de uma discussão entre mim e o Guarnieri durante quase seis meses. Passamos esse tempo trabalhando, principalmente, a atualização da peça, escrita em 1955, para o 1979 das greves e do surgimento das lideranças sindicais. (...) o desafio era saltar do espaço familiar do texto original para um espaço social mais amplo, das fábricas e das ruas. No filme, a fábrica existe, assim como a repressão policial. A realidade da violência urbana, diferente de 1955, a realidade da violência de setores do regime autoritário, a violência interfamiliar, a violência do cotidiano são elementos que surgiram ou se desdobraram com o passar dos anos e vieram à tona no filme. Foi árdua a tarefa de recuperar a mesma emoção com que o Guarnieri a escreveu de um só fôlego, quando tinha apenas 21 anos. E acabar com a insegurança que existia na época em que escrevíamos, em plena abertura do regime militar. (pp.53-54). Eu também não uso blacktie. In: Leon Hirzman - É Bom falar (mostra Leon de ouro, Centro Cultural Banco do Brasil), Rio de Janeiro, 1995.

${ }^{41}$ Na mesma entrevista, o cineasta Leon Hirszman afirmou: “(...) No filme, há maior complexidade. Não deu para colocar Otávio simplesmente esquematizado. O personagem se subdividiu. Dele saiu um Otávio mais amadurecido, que esteve preso, e pagou o preço da radicalização. (...) Mantivemos o conflito desse Otávio amadurecido com o filho para não prejudicar o desenvolvimento do drama. (p.54)
} 
sair cedo de casa e entrar logo para o trabalho. A sequência em que Tião fura a greve é o complemento da sequência em que Otávio e Tião discutem à mesa de jantar após um dia de trabalho.

Mesmo numa observação mais prosaica, proveniente do senso comum, parece aceitável a constatação de que nas relações entre pai e filho há uma possibilidade grande de que ocorra um aprendizado. Em outras palavras, que o filho comece o seu aprendizado do mundo pela educação doméstica e que tenha na presença do pai um modelo, que não necessariamente ele vá seguir. Há uma sequência emblemática a este respeito, que aliás talvez seja uma das mais belas do filme nessa relação entre Otávio e Tião. É uma sequência que foge ao enfoque principal da narrativa na questão política, no início do que chamamos bloco 3. Vamos reproduzir o resumo que fizemos da cena, para desenvolver algo que acreditamos reforçar nossa hipótese de que o maniqueísmo entre pai e filho foi evitado, e substituído por outro modo de expressão com mais nuances. Além disso, a construção da cena obedece a um critério observado na caracterização do quarteto Maria, Romana, Otávio e Tião, em que por uma pequena fissura na densidade da história transfigurada em drama, percebemos a fraqueza deles. É por onde a sensibilidade com as fraquezas humanas, e portanto, com o lado mais humano, retira-lhes completamente uma carga que poderiam ter de "realismo soviético". No restante do elenco de personagens do filme, notamos que a ausência exatamente destes traços de humanidade, empresta-lhes um caráter mais de "personificações" de forças políticas no sentido da sua positividade. São como forças em confronto na arena política construída pelo enredo, com a finalidade de expor um outro lado da tragédia humana, que seria a dimensão social da greve. São heróis positivos, mas construídos de forma convincente, mesmo que não saibamos nada de suas famílias ou de suas histórias de vida. Forças cegas que se lançam no destino como Bráulio, que é assassinado por 
policiais durante os piquetes da greve, porque tentava impedir que Sartini e os companheiros se ferissem, visto que o aparato de repressão havia nitidamente aumentado. Talvez resida aqui, nestes pormenores do filme, o aspecto trágico que ronda o essencial formado pela sobreposição de realismo e melodrama.

"Desta cena em frente à casa de Maria, amanhecemos com Otávio segurando uma xícara de café, observando a paisagem urbana, posicionados às suas costas pela posição da câmera. Um som instrumental melancólico ao fundo compõe, junto com Otávio tomando café e a paisagem das casas e ruas do bairro, um quadro sentimental e belo ao mesmo tempo. O homem no seu recolhimento, com a tristeza do cotidiano pesando sobre si, quando ninguém repara. Tião toma café da manhã e se desculpa com o pai. Ambos conversam e Otávio revela sua desconfiança de que Maria está grávida. Ambos se reconciliam e tudo parece encaminhar para um desfecho que recolocaria Tião ao lado do pai, contra Gesuíno. Pelo menos, em termos de posicionamento em relação à greve, a narrativa abre a perspectiva de que pai e filho acabariam se entendendo."

Descrever essa cena é mais importante do que comenta-la, porque se torna mais verídica a suposição da pedagogia da emoção. De maneira que simpatizamos com os dois protagonistas, acreditando numa moral da consideração recíproca que não se deixa engalfinhar no redemoinho das emoções turbulentas das lutas políticas. E a cena se encerra com os dois saindo juntos para o trabalho na fábrica. O melodrama subsequente a esta cena, ou inerente nesta própria cena, não é apenas escolha do cineasta, mas parece ser um condicionante do nosso olhar contemporâneo sobre as vivências mais íntimas, considerando que vivemos sob a égide de uma outra poética, menos trágica. 
Examinando agora os mitos de Édipo e de Hamlet, presentes na dramaturgia ocidental acerca das relações entre pai e filho, com profundas implicações na psicanálise do século XX, tentaremos refletir brevemente sobre o enfoque filosófico conferido a Otávio e Tião. Segundo Slavoj Zizek ${ }^{42}$, “(...) A oposição básica é entre Édipo e Hamlet: Édipo realiza o ato (de matar o pai) porque não sabe o que está fazendo: ao contrário de Édipo, Hamlet sabe, e, por isso, é incapaz de prosseguir o ato (vingar a morte do pai). Além disso, como enfatiza Lacan, não é apenas Hamlet que sabe, o pai de Hamlet também sabe misteriosamente que está morto e até como morreu, em contraste com o pai do sonho freudiano, que não sabe que está morto - e é esse conhecimento excessivo que explica a mínima propensão melodramática de Hamlet. Ou seja: em contraste com a tragédia que é baseada em um equívoco ou ignorância, o melodrama sempre envolve um conhecimento inesperado e excessivo, não da parte do herói, mas do seu outro, o conhecimento transmitido ao herói exatamente no fim, na reviravolta melodramática final." (p.15)

Como afirmou o filósofo esloveno Slavoj Zizek, o que caracteriza a tragédia antiga estaria formulado nas seguinte proposições "ele faz porque não sabe o que está fazendo", no caso de Édipo e "ele sabe e por isso, não consegue prosseguir no ato", no caso de Hamlet. Já para o herói melodramático, funcionaria uma outra lógica expressa nos seguintes termos: "ele sabe o que faz, e nem por isso, deixa de fazê-lo".

Há o Outro que para Slavoj Zizek, dentro da perspectiva psicanalítica de Lacan, seria o repertório simbólico social, na qual o sujeito está mergulhado e por onde formamos a nossa individualidade pelo "terror" que a realidade provoca. Pensando nos heróis das tragédias antigas, como Édipo e Hamlet, o peso desse repertório simbólico do passado é enorme, e praticamente o seu sofrimento é inevitável. A tragédia transitaria do desconhecimento total do destino ou até do excesso de conhecimento acerca deste, provocando a queda do indivíduo no que segundo Zizek seria o "deserto do real".

\footnotetext{
${ }^{42}$ ZIZEK, Slavoj. Alguém disse totalitarismo? - cinco intervenções no mau uso de uma noção. São Paulo, Boitempo, 2013.
} 
“(...) Em contraste com a tragédia que é baseada em um equívoco ou ignorância, o melodrama sempre envolve um conhecimento inesperado e excessivo, não da parte do herói, mas do seu outro, o conhecimento transmitido ao herói exatamente no fim, na reviravolta melodramática final”, assim conclui o trecho citado acima de Slavoj Zizek. Em comparação, nosso par de heróis ou antiheróis, Otávio e Tião, vive a reviravolta melodramática final chegando cada qual ao seu próprio "deserto do real". Ou seja, a forma canônica do melodrama é "esvaziada" de sentido, e mesmo a dimensão trágica da dissolução da família ocorre por um viés irônico, na constatação de que Tião furou a greve "sabendo o que fazia, e nem por isso, deixou de faze-lo".

Prosseguiremos com um trecho da análise de Iná Camargo Costa sobre a peça teatral Eles não usam blacktie: “(...) Do ponto de vista da forma, podemos dizer que essa peça é o drama de um jovem trabalhador, bem-intencionado mas em conflito com a situação em que vive, às voltas com o desejo e a necessidade premente de se casar (pois a namorada está grávida) e posto diante de um dilema que vai decidir toda a sua vida: aderir à sua classe participando da greve ou recusá-la, buscando individualmente uma saída pela aposta na ascensão econômica e social - o que nos termos da peça se explicita no ato de furar a greve. Por esse lado, a reconstituição da peça deverá privilegiar materiais irrelevantes (ou de importância reduzida) segundo o assunto. É assim que a divisão em atos corresponde a três momentos decisivos na vida de Tião: o primeiro expõe a notícia da gravidez de Maria, a decisão de apressar o casamento, sua preocupação com a greve que se aproxima (e torcida contra), a festa de noivado e a notícia de que a assembléia aprovou a greve. Agora a greve assume uma função dramática, de suspense e maus presságios. E como é impossível, desse ponto de vista, eliminar a sua carga de 'desmancha prazeres', para a festa de Tião não acabar nesse clima, o dramaturgo deu um jeito de providenciar um acontecimento feliz para o 
desfecho do ato: a realidade da peça, a festa acaba com a notícia de que nasceram gêmeos na vizinhança. O segundo ato, sempre desse ponto de vista, tem aquele problema já referido da perda do vigor dramático. É um tempo de espera, em que se revela melhor o caráter de Tião. Temos então um momento climático de importância decisiva no diálogo entre Tião e Jesuíno, no qual ficamos sabendo do processo de amadurecimento da decisão de furar a greve por parte de Tião e, por contraste, do caráter oportunista de Jesuíno.(...) o terceiro ato, como apontou Sábato Magaldi recupera a tensão dramática perdida no segundo. Mas, sendo o drama escrito da perspectiva de Tião, a cena lhe é literalmente roubada pelo crescimento de todos os outros personagens, o que complica um pouco a estrutura dramática da peça." (pp.31$35) .^{43}$

Nesse trecho da análise de Iná Camargo Costa, entre outras coisas, há uma visão panorâmica dos três atos em que se divide a peça teatral Eles não usam blacktie. E podemos perceber as alterações promovidas por Leon Hirszman e Guarnieri no enredo para o cinema. E assim, pretendemos recolocar a problemática central, que do nosso ponto de vista, foi transposta da peça teatral para o filme, em outros termos. A estrutura dramática é basicamente a mesma, ou seja, há o conflito entre pai e filho por causa da greve na fábrica onde trabalham. Tião se vê cercado pelo mesmo dilema de ter de sustentar a namorada grávida e o filho que nascerá, dominado pela angústia de se encontrar, de repente, desempregado. Os três atos em que se divide o drama teatral desapareceram, porque o cinema apresenta o recurso da espacialidade que amplia o único ambiente doméstico para o ambiente da rua e da fábrica. Mudou a perspectiva da forma, na terminologia de Iná Camargo Costa, que na peça, era de Tião compondo três momentos decisivos na sua vida.

\footnotetext{
${ }^{43}$ COSTA, Iná Camargo. A hora do teatro épico no Brasil. Rio de Janeiro, Paz e Terra, 1996.
} 
Ainda do ponto de vista da forma, a primeira mudança que percebemos diz respeito ao estilo da montagem que alterna cenas de Otávio reunido com os companheiros discutindo política, e cenas de Tião e Jesuíno onde vai amadurecendo a idéia de furar a greve. Desse modo, não podemos afirmar que o filme manteve o ponto de vista de Tião na forma e o ponto de vista de Otávio no conteúdo. O ponto de vista de Otavio se tornou hegemônico em termos de forma e conteúdo, por causa da "presença" do que chamamos arbitrariamente de terceiro elemento da forma, como se se tratasse quase de um personagem oculto.

Enquanto no contexto da peça, o drama de Tião crescia em intensidade e Otávio era o assunto político "reprimido" pela encenação e a condução da emoção do espectador. No filme, parece-nos que a questão política se sobrepõe categoricamente aos próprios personagens. De maneira que o ponto de vista de Otávio prevalece, mas totalmente fora do seu controle. Ou seja, Otávio é esmagado pela realidade "trágica" que o envolve, e que não se resume apenas às incertezas em relação à greve, mas assume um caráter de que Otávio representa a existência em consonância com os valores coletivos pelos quais ele luta há muito tempo. Estamos considerando a diegese do filme, como analisamos até aqui, e por esse motivo, Tião, por outro lado, representa a existência "alienada" que é parte do mesmo processo social.

Na cena mais importante do filme, do ponto de vista da discussão da história, e que pode reforçar a tese de que opera na sua estrutura uma pedagogia da emoção se passa no ambiente doméstico, quando Otávio e Tião se desentendem quanto às motivações por trás das demissões na fábrica onde trabalham.

A sequência encontra-se no bloco 3 da nossa análise, quando Tião adverte Otávio para tomar cuidado comas demissões praticadas sistematicamente pela direção da fábrica. Otávio responde que pelo fato de ter o apoio da turma, a direção da fábrica 
não o demitiria para evitar problemas maiores com o pessoal mobilizado. Tião insiste e acrescenta que ele não está preparado para sustentar duas famílias. Toda esta sequência é construída de maneira bem engenhosa, com a câmera se movendo de um ator para o outro, isolando-os em closes americanos ou enquadrando toda a família ao mesmo tempo. Pequenos cortes entre os planos, ou apenas movimentos lentos da câmera, vão produzindo o efeito de uma tensão que anima os debatedores Otávio e Tião e os outros membros da família reunidos para o jantar: Romana, a única que intervém, Chiquinho, o irmão mais novo de Tião e a sua namorada Teresinha não participam da discussão, são apenas platéia. Enquanto a sopa vai sendo servida e todos comem, Tião vai se irritando com a provocação de Otávio, que faz um verdadeiro discurso:

- Quinze anos de ditadura! É fogo! Marca a gente! E você continua pensando como se nada mudasse! Poça d'água! É preciso enxergar a água corrente!

Tião responde:

- Poça d'água, água corrente, fala que nem louco pai! E a gente é que precisa mudar! Sempre dando duro naquela bosta daquela fábrica, preso meio morto de porrada, e eu que não consigo enxergar? Sempre na merda! E o senhor com essa história de que é preciso organizar! Olha o histórico da classe trabalhadora! Sempre na merda!

Romana, neste momento, assume o papel de representar a voz do cineasta, assim talvez como Bráulio no cenário externo da greve, que intervém, e assim como Otávio fizera, faz uso, por sua vez, de uma metáfora. A coisa se passa mais ou menos assim: Tião levanta-se da mesa, empurrando a cadeira com agressividade. Ele faz um gesto de "banana" para o pai e se retira para o seu quarto, batendo a porta com força. Nesse momento, o restante da família, num silêncio de perplexidade com a cena entre Otávio e Tião, ouve o comentário de Romana:

- É preciso consertar esta porta, senão ela não aguenta! 
Aqui, acreditamos que o conjunto da cena, e o uso das metáforas por Otávio e Romana, representam o ponto de vista do cineasta sobre a história que ele vivenciou e refletiu, recuperando em termos artísticos a discussão de que o PCB não era mais o "partido da classe operária”, como historicamente havia sido. “(...) As transformações vivenciadas pela sociedade brasileira foram intensas ao longo de mais de duas décadas de vigência da ditadura. E o PCB, pouco a pouco, teve que lidar com circunstâncias que o levaram a posições cada vez mais secundarizadas, não só em termos sindicais, mas também em termos políticos gerais. Nesse sentido, o partido enfrentou uma realidade emergente em termos políticos e sindicais que se plasmou, em 1980, em torno do PT. Os metalúrgicos fizeram novas greves em 1979 e 1980, enfrentando forte resistência de patrões e do regime militar, o que levou até a intervenção no sindicato. $O$ avanço das lutas operárias no $A B C$, em sentido distinto daquele propugnado pelos comunistas, fez com que o PCB passasse a criticar algumas posições presentes na condução da greve. A posição do partido era de que a luta operária contra o arrocho, pilar da política econômica da ditadura militar, teria que se inserir na luta pela consolidação da democracia no Brasil (e de certo modo se subordinar a ela). A subordinação da luta social à luta política - a primeira, de extração operária, e a segunda, de perfil policlassista - acarretou o distanciamento dos comunistas em relação aos novos contingentes da classe operária." $(p .385)^{44}$

Otávio é Leon Hirszman, posicionando-se contra as críticas de Tião que nesta discussão com o pai, sobretudo, faz o papel da opinião pequeno-burguesa, socialdemocrata ou do MDB. Talvez, Tião optasse pelo MDB como partido policlassista

\footnotetext{
${ }^{44}$ SANTANA, Marco Aurélio e ANTUNES, Ricardo. "O PCB, os trabalhadores e o sindicalismo". In: História do Marxismo no Brasil - Partidos e Movimentos após os anos 1960. Campinas, SP, editora da Unicamp, 2007.
} 
adequado a sua identidade, como alguém que desejava mudar de classe social, em oposição à ideologia comunista do pai, nitidamente referenciada no PCB.

“(...) O fato é que o PCB, quase no mesmo momento em que se via acuado, denunciado no campo cultural como cerceador da liberdade criativa - como atesta o episódio das 'patrulhas ideológicas' - perdia espaço nos movimentos sociais de massa. No campo sindical, via crescer o 'Novo Sindicalismo' e as oposições sindicais que questionavam o 'peleguismo' dos dirigentes sindicais comunistas. No movimento estudantil, as grandes passeatas de 1977 foram capitalizadas pelos trotskistas, inimigos históricos dos pecebistas, e pelos católicos de esquerda, reunidos, respectivamente, nas tendências estudantis "Liberdade e Luta" e "Refazendo". A desconfiança do partido em relação à juventude radicalizada (resquícios dos dissensos de 1968) e ao sindicalismo orgautonomista foi crucial para o esvaziamento político do Partidão nos movimentos sociais de massa. O partido não deu grande destaque à greve metalúrgica de 1978, tida como 'anti-patronal' e espontaneísta, portanto, limitadas politicamente. A radicalização do movimento operário em 1979 chamou a atenção do 'Partidão', que tentou rever suas posições e organizar a ação dos seus militantes sindicais para garantir a 'unidade' do movimento, ou seja, afirmar a hegemonia comunista. O PCB chegou a saudar 'as entidades e movimentos de massa' da sociedade civil, cuja ajudava a recolocar as classes populares como ator da política, mas deixava claro que elas deveriam ser o 'centro aglutinador' de uma frente antifascista...conjugando sua luta c'om a da oposição parlamentar, aliando-se a 'amplos setores da sociedade', criando condições para a formação de um amplo bloco democrático no Congresso, com amplo respaldo das massas'. O consenso das oposições de esquerda, já questionado em 1977, ficava completamente inviável a partir de 1980. A criação do Partido dos Trabalhadores ia na contramão do frentismo comunista com ênfase na luta 
parlamentar. Animado pela esquerda não-comunista, o PT era publicamente defendido pelos novos dirigentes sindicais e se propunha a ser um 'partido-movimento' crítico do aliancismo e da política institucional. Paradoxalmente, a Anistia oficial de agosto de 1979, ao invés de engrossar as fileiras da sonhada frente democrática dos comunistas, com a volta das lideranças exiladas, só exacerbou sua crise. No ano seguinte, o PCB 'rompia' com a Igreja, ainda que seus militantes de base atuassem lado a lado nas lutas sindicais e políticas contra o regime militar. No plano cultural, a cisão da frente e do consenso nas palavras de ordem e nas táticas de luta contra o regime também se explicitaram. O frentismo cultural que guiava a militância cultural comunista e os valores do nacional-popular passaram a ser duramente criticados pela esquerda católica e pela nova esquerda como um todo. O nacional-popular cepecista passou a ser vista como símbolo de uma ação cultural autoritária, mistificadora e, no fundo, afeita às regras do mercado e facilmente enquadrável no nacionalismo oficial do regime. Para a nova esquerda, o manifesto do CPC era a prova deste desvio 'nacionalpopulista', que ao tentar enquadrar a 'cultura popular', a enfraqueceram. ",5

Tendo como referência historiográfica os trechos citados acima, vamos analisar o trio Otávio-Tião-Romana, e os pares Otávio-Sartini, Bráulio-Sartini. Também, arriscaremos uma interpretação para as metáforas de Romana e Otávio na discussão política com Tião. E, por fim, articular pedagogia da emoção com essa discussão política.

O trio Otávio-Tião-Romana, encena uma discussão que é na verdade, a alegoria de uma outra discussão bem mais abrangente, sobre o futuro. A metáfora da água corrente, considerada estritamente no contexto em que o argumento principal do filme

\footnotetext{
${ }^{45}$ NAPOLITANO, Marcos. Coração Civil: Arte, Resistência e Lutas Culturais durante o regime militar brasileiro (1964-1980). Tese de Livre Docência apresentada à FFLCH, Departamento de História, 2011.
} 
foi sendo articulado nas sequências anteriores, refere-se ao imperativo de retomar o controle sobre o movimento operário, antes que se perca a oportunidade posta diante deles pela história. Tião responde que isso é loucura, e enumera os erros do passado do pai, que inclusive, na sua própria fala também se confunde a história do movimento operário que confiava no $\mathrm{PCB}$, e finaliza com um gesto radical de ruptura. Tião, no contexto desta discussão, assume o papel das vanguardas que Marco Aurélio Santana e Ricardo Antunes denominaram no seu artigo de Novo Sindicalismo, visto que ele ainda é operário e pensa diferente do pai. Tião e Gesuíno desejam ser promovidos na fábrica, pelo conchavo e delação dos operários grevistas, como se tratasse de um peleguismo às avessas, atribuído propositalmente pelo cineasta ao par, ao contrário do que propõe, por exemplo, Marcos Napolitano na sua tese de livre-docência citada várias vezes neste trabalho, e que o peleguismo estaria relacionado às lideranças tradicionais do PCB.

Romana utiliza a metáfora da porta para aludir ao perigo de que a união da família não é mais tão sólida, que é preciso consertar, corrigir, para que pai e filho não coloquem portas entre si. A resistência da porta, também pode ser uma interessante forma de se falar sobre a resistência ao regime militar que corre o risco de "quebrar" a união, a "frente democrática", pelas divisões internas e rachaduras no campo da esquerda. Otávio-Tião no plano familiar seria uma oposição correspondente a OtávioSartini no plano da luta operária e da concorrência pela hegemonia do PCB ou da "nova esquerda" que quase majoritariamente formaria o PT. Porque se observarmos basicamente as discussões entre Otávio e Sartini, são embates entre a proposição do confronto com a ditadura militar e a moderação política, que consideraria o movimento operário um apêndice da base pluriclassista para se chegar a compor com a "abertura", propugnada por setores mais progressistas das forças armadas. 
Braúlio, como já adiantamos, não é um personagem com traços muito definidos, mas atuaria como elemento chave do amálgama meio confuso do epílogo do filme, que conjugaria numa mesma alegoria "religiosidade" e "marxismo". Não é possível cravar muito nitidamente a sua filiação teológico-política, como sendo teologia da libertação, JUC, CEB, pastorais,etc. Mas, como contextualizou Michael Lowy ${ }^{46}$ :

“(..) Trata-se de uma ampla e complexa rede que ultrapassa os limites da Igreja como instituição e reúne, a partir dos anos 70, milhões de cristãos que partilham 'a opção prioritária pelos pobres'. Sem a existência desse movimento social, que poderíamos designar pelo termo 'cristianismo da libertação'- o que inclui ao mesmo tempo uma prática social emancipadora, novas formas de prática religiosa e uma reflexão espiritual (mais tarde teológica) que corresponde a essa experiência -, é impossível entender o conflito entre a Igreja a o regime militar ao longo dos anos 70, assim como, a partir de 1978, o espetacular surgimento de um novo movimento das classes subalternas, dos trabalhadores da cidade e do campo: o Partido dos Trabalhadores (PT), a Central Única dos Trabalhadores (CUT) e o Movimento dos Trabalhadores Rurais Sem Terra (MST). Com efeito, grande parte dos militantes e quadros dirigentes dessas novas organizações vem das CEBs e pastorais populares, e é no cristianismo da libertação que se encontra a motivação primeira de seu compromisso social e de sua 'mística' política." (pp.411-412)

No bloco 4 da análise, há uma sequência relativamente curta, mas bastante significativa do papel de Bráulio no enquadramento geral da questão operária que Leon Hirszman pretende fazer ao retratar discussões entre operários no seu filme. Numa manhã de domingo, ao lado do terrão onde ocorre um jogo de futebol, Sartini joga

\footnotetext{
${ }^{46}$ LOWY, Michael. Cristianismo da libertação e marxismo - de 1960 a nossos dias. In: História do Marxismo no Brasil- vol.6. Campinas, SP, 2008. (pp.411-438)
} 
bocha com alguns companheiros de fábrica. Chegam Otávio e Bráulio. Inicia-se uma discussão entre Otávio e Sartini, acerca das demissões na fábrica, das quais o próprio Sartini fora prejudicado. Otávio acusa a direção da fábrica de espalhar boatos sobre as demissões para dividir os operários. Sartini acusa Tião pela sua demissão, afirmando que este estaria entregando os operários para a direção da fábrica. Otávio avança sobre Sartini, mas a briga é apartada pelos outros operários. Bráulio intervém, retirando simbolicamente a bola de bocha da mão de Sartini, que poderia usa-la para agredir Otávio.

- Para! Vamos tomar um negocinho aí pra esfriar a cabeça! Não é questão pessoal! É política! - Assim, Bráulio tranquiliza os companheiros, recolocando o foco na "união" contra o verdadeiro inimigo dos trabalhadores. Há uma equivalência entre Bráulio e Romana, assim como entre a esfera reivindicativa da fábrica e a esfera regenerativa do lar. Sartini e Tião se equivalem na função de confrontar Otávio, tornando mais complexo o conflito que se reduziria a um acerto de contas entre pai e filho. A intervenção de Bráulio na oposição entre Sartini e Otávio, acrescenta mais um elemento político na discussão que o filme incorpora como forma melodramática, cuja importância repousa no campo alegórico. Ao final do que consideramos o bloco 5 da análise, que corresponde ao momento após a cena em que Tião e o pai discutem na porta da fábrica, no que se consuma o ato de furar a greve. Tião e Gesuíno trabalhavam na linha de montagem, quando Tião é chamado para atender um telefonema. Tião é dispensado do trabalho para encontrar Maria que estava hospitalizada, após ter sido agredida por um policial à paisana, infiltrado entre os grevistas. Ao sair dos portões da fábrica, Tião é perseguido e agredido por operários que esperavam os fura-greves. Na confusão, aparecem Bráulio e um outro operário que salvam Tião de ser linchado. Num gesto muito parecido com o que descrevemos naquela discussão entre Otávio e Sartini, 
próximo ao campo de futebol, as palavras são proferidas a favor da moderação. Bráulio fala aos companheiros que há muito a ser feito, que há reunião no sindicato, e que ninguém deveria importar-se tanto com Tião, que afinal de contas, não passava de um egoísta. Enquanto proferia seu discurso, o grupo de agressores foi se dispersando, a tropa de choque se aproximava, e Tião fugia machucado. Se pensarmos nos dois momentos conflituosos em que Bráulio intervém, recolocando o foco na questão operária, na moderação, na perspectiva talvez da "frente democrática", sua atuação é crucial para a construção da alegoria pretendida por Leon Hirszman.

Como afirmou Michael Lowy:

“(...) O mais importante é que, a partir dos anos 80, ele se tornará um dos principais ingredientes na constituição da cultura sociopolítica - já secularizada e nãoconfessional - do Partido dos Trabalhadores, da Central Única dos Trabalhadores, do Movimento dos Trabalhadores Rurais Sem Terra e de outros movimentos sociais. Os militantes cristãos, numerosos tanto na base como na direção dessas novas forças - as quais vão contribuir para a auto-organização, conscientização e politização das classes populares no Brasil, num grau sem precedente na história do país - , não constituem uma corrente distinta, mas participam das várias tendências sindicais ou políticas que se manifestam em seu interior." $(p .428)^{47}$

O que o Michael Lowy denomina de "cristianismo da libertação", foi uma tendência que aglutinou diversos tipos de militantes, em que a tônica consistiu na aproximação, não sem tensões, entre marxismo e teologias cristãs. Apostamos neste enfoque para Bráulio tomando por base, o epílogo do filme. Neste último bloco da análise que corresponde ao velório de Bráulio, à cena dos feijões e a passeata-cortejo apoteótica, percebemos a consumação da alegoria maior do filme. A pedagogia da

\footnotetext{
47 Idem.
} 
emoção ganha aqui uma dimensão maior do que na cena dos feijões, que se passa no âmbito doméstico. Qualquer simbolismo aqui é maior, porque trabalha a dimensão da multidão na rua, cuja mística conjugação de ritual religioso e reivindicação política, extrapola os portões da fábrica. O racionalismo de Otávio, é absorvido pela emoção da comunhão mística com as forças populares em passeata, e todos os personagens desse drama operário, carregam o caixão de Bráulio. Bráulio transforma-se em mártir, com todo o peso ideológico da sua condição de proletariado. O indivíduo morre, mas a multidão vai às ruas, reivindicar que a "greve continua!", na união de Otávio e Sartini, na presença das mulheres Romana e Maria, da mãe de Maria, de Alípio, o dono do bar. Até o violeiro anônimo participa da passeata-cortejo, Chiquinho que ouve de Otávio, durante o velório de Bráulio que não apenas este, mas o movimento operário, do qual Bráulio fazia parte, seria lembrado na história do Brasil. Não há quadro mais pungente, e ao mesmo tempo "pluriclassista" que este, formado pelos operários em união com a população nas ruas, numa alegoria final sobre a "frente democrática". 


\subsection{Estrutura dramática e luta e classes}

No filme, há uma problematização das relações entre forma e conteúdo, provenientes do contexto social, em que memória da experiência política e conjuntura política imediata disputam espaço na estrutura do melodrama.

Trata-se de uma alegoria da questão operária tratada na perspectiva da transição do papel de protagonismo do PCB para uma nova reordenação das forças da esquerda, em que o partido mais importante da classe operária perde o controle sobre o movimento grevista que se radicalizou, numa conjuntura de mudanças e surgimento de novos atores políticos em cena, com todos os desdobramentos que as "rupturas" históricas provocam.

Parece-nos, que o movimento do filme, é condizente com o argumento político principal, centrado na relação dialética entre família operária e organização grevista. Essa pretensão esbarra na forma dramática, que oscila entre a necessidade de manter-se coerente com o conflito melodramático Otávio-Tião e ao mesmo tempo, sustentar a construção de uma alegoria do movimento operário dentro do corte desejado por Leon Hirszman.

Essa noção de um "eu épico" que irrompe na crise da forma dramática burguesa está em Peter Szondi, que utilizamos como uma das premissas fundamentais para nossa tese principal acerca das tensões entre forma e conteúdo. Além disso, procuramos conjugar nossa tentativa de fazer a análise fílmica dentro do pressuposto teórico de que "cada filme define um modo particular de organizar a experiência em discurso, sendo um produto de múltiplas determinações". ${ }^{48}$

\footnotetext{
${ }^{48}$ XAVIER, Ismail. Sertão Mar - Glauber Rocha e a estética da fome. São Paulo, CosacNaify, 2007.
} 
A peça teatral Eles não usam blacktie de 1955, já apresentava um Otávio engajado com a causa operária, expoente de uma corrente atuante do PCB. Otávio é um operário que transita da década de 1950, com as grandes greves históricas, e da pujança de uma movimento operário capaz de pesar decisivamente nas mudanças políticas desde o trabalhismo na Era Vargas, passando pelo período JK, e na oposição contra a ditadura militar. $^{49}$

No filme, Otávio advoga a organização da classe trabalhadora como prerrogativa fundamental para conquistas políticas graduais e mais duradouras, os tempos mudaram, o PCB enfrenta os impasses da reorganização para a própria sobrevivência como partido da classe trabalhadora. O PCB foi confrontado pelos movimentos sociais de tendências sociais democratas e sociais cristãs.

Há uma dimensão mais integrada com o cotidiano dos operários, com a experiência da luta diária, constituindo um militante mais popular do que propriamente um "intelectual” doutrinando as massas. Há ainda, mesmo que eu não possa provar de maneira enfática, uma alusão às novas lideranças sindicais do $\mathrm{ABC}$ Paulista conformando parte do perfil militante de Otávio. E há, também, traços de "memória política" recente em Otávio, que o transformam numa voz importante do discurso cinematográfico que falávamos anteriormente. Por todas as razões óbvias que fazem de Otávio o herói do drama encenado com todas as enormes dificuldades para organizar o movimento grevista, este personagem verbaliza uma memória da resistência popular contra a repressão da ditadura militar. Não estou me referindo apenas à associação direta que podemos fazer com o aparato policial que reprime os operários durante a greve que ocorre no filme. Trato de certos "fragmentos" de sentido que se encontram

\footnotetext{
${ }^{49}$ SKIDMORE, Thomas. Brasil: de Getúlio a Castelo. São Paulo, Paz e Terra, 1996.
} 
espalhados pela narrativa, que estão nas falas de Otávio e nos "espaços" se transformam em espaços políticos.

Num primeiro momento, o que designamos como bloco 2 da análise, que compreende 53 planos, fixa alguns traços que acentuam as diferenças de engajamento político entre pai e filho. Em 20 planos, no bar do Alípio, que já havia aparecido nas primeiras cenas do filme, quando policiais foram responsáveis por uma situação de preconceito contra o violeiro que é figura constante ao longo da narrativa, Tião e Jesuíno discutem duas posições em relação à greve anunciada na introdução. Tião se prende a uma razão prática para furar a greve com a justificativa de que a "greve é um direito, e se não se quer dispor desse direito, não há problema.” Jesuíno parece menos ingênuo do que Tião, e percebe que não é possível furar a greve sem enfrentar a revolta dos companheiros da fábrica. Tião convence temporariamente Jesuíno de que a sua forma de furar a greve é fruto de um posicionamento político irrepreensível. Jesuíno contrapõe a experiência de que é necessário um acordo com a direção da fábrica, para efetivar a promoção na carreira ao custo da derrota do movimento grevista.

Apesar de toda a despolitização que o cineasta admitiu ter operado na construção do personagem Otávio, ele tem umas tiradas "brechtianas". Na sequência em que Tião fura a greve, a que já nos referimos linhas acima, Otávio é preso por policiais e conduzido para o camburão. Essa sequência possui um forte apelo épico. Ele discursa, num primeiro momento, para um grupo de operários encostado no muro próximo ao trailer, “ A greve é a arma de luta do trabalhador! Somos nós que sustentamos os poucos

\footnotetext{
${ }^{50}$ SANTOS, Milton. O espaço do cidadão. São Paulo, Edusp, 2002. Considero que o espaço urbano representado no filme guarda certos pontos de contato com o espaço da cidadania de que fala Milton Santos. "(...) No Brasil, o 'milagre econômico', com sua enorme força ideológica, muito maior que os seus resultados concretos e materiais, agiu como um dissolvente eficaz. A sensação do bem-estar rapidamente obtido - e quantas vezes sem mérito! - pelas novas classes médias dava-lhes a impressão de realização pessoal. A ideologia da prosperidade contaminava a sociedade de alto a baixo, enriquecendo de sonhos injustificados quem jamais deixaria de ser pobre." (p.52).
} 
que entraram aí!...Mas, conforme se aproxima do camburão, afirma para o espectador “Olha gente! É assim que tratam o proletário brasileiro!” A impressão é que ele discursa para os mesmos operários, mas o recurso é engenhoso e a sua fala é na verdade, dirigida ao espectador.

Somos conduzidos frequentemente pela montagem, para o outro polo da questão, que se pretende encaminhar ao telespectador, onde acompanhamos Otávio e Bráulio distribuindo panfletos da greve e sendo interrompidos pela polícia. Aqui também percebemos o mesmo esquema de "modulação" do engajamento político, apresentando Otávio e Bráulio como "moderados" e Sartini, o operário italiano companheiro de fábrica e sindicato, como "radical". Com isso, a primeira impressão que formamos a respeito do tema principal do filme que é a greve na fábrica, é essa diferenciação nos comportamentos de Tião e Otávio. Formam-se assim os dois polos antagônicos da narrativa, um que reúne Tião e Jesuíno e o outro, basicamente, Otávio, Bráulio e Sartini. O polo da ação individual apresenta, portanto, Jesuíno como "radical" disposto a qualquer negócio para subir na vida e Tião meio "hesitante" apesar de expor a sua teoria de furar a greve como escolha "consciente". Do outro lado, Otávio e Bráulio procuram conter o entusiasmo dos companheiros, sobretudo de Sartini, disposto a tudo para começar logo a greve. O posicionamento "radical" fica restrito ao personagem Sartini e parece que, com isso, o filme é um tanto "hesitante" em apresentar uma perspectiva de engajamento explícito com a greve, e talvez com o momento político que se vivia em relação às greves do $\mathrm{ABC}$ e ao carisma das novas lideranças do movimento operário. A "hesitação" de Otávio e Bráulio revestem-se de certa precaução em não tornar o filme uma espécie de propaganda do momento político vivido no início dos anos 1980 no ABC Paulista. Ao mesmo tempo, a definição dessas duas categorias de 
operários: moderados e radicais, simplifica demais a abordagem do espectro político em jogo naquele período de confronto com a ditadura militar.

Esses dois polos assim definidos acima, nos colocam a princípio diante de duas posições conflitantes, duas opções diferentes de como considerar a greve: a primeira entende a greve como obstáculo para objetivos pessoais, e a segunda, é a mobilização coletiva pelo convencimento, ou pela "conscientização" das massas.

Tião parece ter assimilado mal a gravidez da namorada e se aflige pela pobreza que os aguarda, por todo o conforto que ele não poderá oferecer. Aos poucos, o segredo da gravidez vai se revelando para as pessoas mais próximas, Jesuíno, Otávio e Romana. A apresentação desses dois polos pressupõe uma tensão dramática que se confirmará ao longo da narrativa. Essa predisposição ao confronto é apenas possibilidade mas já apresentava desde o início demarcações ideológicas bem nítidas. O filme transita pelas duas opções, conferindo até este momento, um peso igual para ambas. Conforme prosseguirmos com a análise, tentaremos perceber como essa tensão entre pai e filho vai se modificando durante o filme.

Ainda neste bloco 2, os planos 39 a 53, apresentam a primeira conversa entre Otávio e Tião que ocorre no bar do Alípio. Tião estava retornando de um encontro com Maria, com quem passara todo o domingo. Aliás toda essa sequência 2 do filme se desenrola num fim de semana, passando pelo sábado à noite no cinema, pela manhã de domingo no bar com cerveja e bilhar, pelo passeio na represa, pelo namoro e pela saideira no bar do Alípio onde Otávio e Tião conversam. Otávio aguardava pelo filho, sentado numa mureta próxima à casa deles, e convida-o para "tomar uma no Alípio" e conversar. Tião aceita a contragosto preocupado com o horário. No bar, os 14 planos que seguem, colocam o espectador diante de uma conversa em que Otávio aconselha Tião a buscar aprender mais com ele, veterano na vida e na luta sindical. Tião responde 
que também "é de briga" e que sabe perfeitamente o que fazer. A conversa é interrompida pela entrada de um jovem armado no bar, seguido por policiais que o perseguem. Com o recurso de elipse, a câmera mostra as expressões de Otávio, Tião, Alípio e o violeiro, enquanto ouvimos os gritos e o som da metralhadora usada pelos policiais. A sequência encerra-se na tragédia do jovem, pobre, negro, marginalizado. É a composição do enquadramento do espectro social da violência na periferia suburbana de São Paulo. Outro claro esforço de enquadramento acontece quando Jurandir, o pai de Maria é abordado por um homem armado que anuncia o assalto. Jurandir ironiza com o assaltante mostrando-lhe os bolsos vazios e é alvejado por tiros de revólver nas costas. Uma outra forma de enquadramento do espectro social é a pobreza do ambiente demonstrada pelas casas da periferia, em closes gerais, utilizados para a mudança de planos.

Otávio claramente propõe ao filho "instruí-lo" para aliviá-lo da confusão em que ele o supõe estar vivendo. Tião resiste e oferece, em contrapartida, uma outra alternativa de ação vislumbrada por ele. Tudo isso é dito de maneira amigável e a conversa não vai muito além de um mero esboço de desentendimento. É uma sequência curta. Mas, para formarmos uma imagem mais ampla de toda a sequência que designamos como bloco2, precisamos considerar que se trata de uma incursão pelo domingo vivido por Tião e Maria, alternadamente, com a saída de Otávio e Bráulio do sindicato. A suposição é de que Otávio e os companheiros operários passaram o dia discutindo sobre a greve. Somos levados a uma comparação entre as duas maneiras de viver o domingo que se apresentavam para o trabalhador: o lazer composto de bar, parque e namoro e a militância dos operários mais engajados. Mas, sobretudo, somos levados a uma comparação entre a maneira como Tião e Otávio passavam suas horas de lazer fora da fábrica. Até aí permanecemos no terreno da montagem que vai alternando as situações 
vividas por pai e filho, colocando-nos a par das diferenças que interessam ao propósito do filme que começamos a vislumbrar. Parece que o propósito dessa apresentação superficial do fim de semana dos trabalhadores é conduzir-nos para aquela conversa no bar entre Otávio e Tião, que confirma suas perspectivas conflitantes. Assim a montagem intensifica essa alternância de pontos de vista, cujo desfecho é a conversa no bar. Esse parece representar o movimento geral em que a montagem do filme constrói o suspense das revelações que se prefiguram nas cenas alternadas que retratam as ações de Otávio e Tião, com o objetivo de confrontar esses dois personagens em falas contraditórias. Tanto as imagens quanto as falas contribuem para indicar o sentido em que se intensificam as contradições que o filme pretende reafirmar a todo o instante, entre pai e filho. Como se o objetivo das sequências fosse não apenas informar as diferenças entre pai e filho, mas direcionar nossa atenção para o conteúdo das discussões travadas entre eles.

No bloco 3, uma primeira sequência com 16 planos descreve o interior da linha de montagem, e termina com Tião e Jesuíno numa conversa durante o almoço no refeitório da fábrica. O teor da conversa entre eles é uma intensificação daquela primeira conversa no bar do Alípio. Jesuíno reafirma a sua tese de "levar vantagem em tudo" e Tião desta vez, é quem se rende ao seu interlocutor, consentindo pelo silêncio em delatar os operários grevistas. Em contrapartida, seguindo a estrutura da narrativa anunciada anteriormente, Otávio e Bráulio encontram-se com Sartini no trailer após o expediente na fábrica e discutem sobre as demissões. $\mathrm{O}$ espectador sabe o que está ocasionando as demissões dos operários grevistas e espera um acerto de contas entre os opositores.

Nesse mesmo bloco, nos planos 17 a 25 ocorre um jantar em família, em que Romana serve sopa e uma segunda conversa entre Otávio e Tião se transforma em 
discussão séria sobre os rumos da greve. Otávio comenta com Romana sobre as demissões dos operários envolvidos com a greve, como "os mais combativos, escolhidos a dedo pela direção da fábrica”. Tião adverte Otávio para precaver-se, sendo mais cauteloso, não expor-se tanto já que ele terá que "sustentar duas famílias", caso o pai perca o emprego. Nesse ponto, começa uma discussão política entre Otávio e Tião, em que aquelas mesmas posições assumidas amigavelmente, cenas atrás, são agora fervorosamente defendidas. O teor político da discussão opõe duas concepções: Tião representando a opção individual de ascensão social contrapondo-se ao argumento de Otávio em favor da organização dos trabalhadores e da única forma de vitória admissível para os operários. Tião apropria-se com ironia da ideologia do pai, falando em "classe trabalhadora" que se organiza de maneira ineficiente, enquanto todos permanecem na "pior". Aqui as contradições entre a ideologia do pai e a ideologia do filho são desmascaradas, pela força alegórica que a conversa carrega com relação ao contexto político, como já tratamos no capítulo anterior. Nosso propósito agora, ao abordar a mesma sequência, é de outra natureza. Procuramos acompanhar o movimento do filme e "questionar" a forma canônica de composição do maniqueísmo, e como, Leon Hirszman driblou, de forma engenhosa, as armadilhas desse gênero de cinema.

Otávio introduz, nesta segunda conversa que se transforma em discussão, consciência histórica acerca da repressão da ditadura militar, as possibilidades do movimento operário e a necessidade de busca da solução coletiva para os problemas da classe trabalhadora. Tião recusa essa forma de compreensão da sua condição operária e acusa o pai de negligenciar a família em detrimento do engajamento político. A negligência do pai, coisa que ele vai corrigir agora em relação a Maria, seria a causa da pobreza da família. O pai não enxerga a situação de maneira realista, rendendo-se sempre às ilusões da ideologia "comunista". Apesar do termo comunismo não aparecer 
em nenhuma das conversas entre pai e filho, as imagens alternadas de suas perspectivas de ação e suas falas nos induzem a considerar essa hipótese. Otávio é comunista e enxerga o mundo pela ótica da transformação coletiva da realidade social. Enquanto Tião transita de uma negação dessa perspectiva do pai, da qual ele possui traços em sua consciência (mais do que Jesuíno, por exemplo), para uma aceitação daquela que seria a ideologia dominante, que Jesuíno expõe a faceta mais "vergonhosa". Insistimos nessa descrição de traços da personalidade política dos personagens Otávio e Tião, porque o filme não faz uma caracterização psicológica muito elaborada. Conhecemos apenas aquilo que nos é oferecido ao olhar, vindo à tona suas inclinações políticas e seus alinhamentos com ideologias que supomos ser a "comunista" e uma outra de feição "liberal econômica" (não a liberal política).

O que nos parece "amarrar" essa segunda discussão, mais do que a primeira, entre pai e filho, é a possibilidade do aprendizado que o mais experiente tenta imprimir ao mais jovem. É uma pedagogia com ênfase na mobilização coletiva, traço bastante reforçado aqui, porque já presente na estrutura do melodrama enquanto linguagem, e como um dos recursos da forma utilizados no filme, que ressalta o caráter didático das falas de todos os personagens do drama Eles não usam blacktie. Otávio é, sem dúvida alguma, o personagem que mais polariza essa pedagogia bem intencionada que constitui o propósito fundamental do filme. O filme, de modo geral, considerando essas sequências que formam os blocos 2 e 3 que estamos analisando, prepara um suspense com imagens (ou ações) que se encaminham para o desfecho com alguma conversa "politizada". Novamente, reforçamos a idéia de que o essencial para o espectador é "participar" destas discussões propositalmente encaixadas ao final das sequências que constituem breves dissertações políticas, e nem por isso, inconsequentes. Cada pequena cena de discussão política de Eles não usam blacktie transita em torno do tema central 
do filme que é a greve dos operários, com toda a carga simbólica dos eventos que mobilizavam militantes e não-militantes no inicío dos anos 1980 no Brasil. Não pretendemos observar neste filme apenas uma mera ilustração daqueles acontecimentos, mas tentar perceber em que medida o contexto histórico brasileiro era tão polarizado quanto a montagem do filme Eles não usam blacktie incorpora em sua composição.

Podemos apontar, agora, com mais elementos, a mudança na tensão entre os pontos de vista de Otávio e Tião, da primeira para a segunda conversa. A alta carga emotiva que acompanha a intensificação da situação criada entre pai e filho, é resultado da dramatização de uma assunto que perde conteúdo acadêmico (e portanto, intelectualizado) para assumir um maior envolvimento com o movimento popular e suas resistências internas. Parece que o cineasta abre mão de uma interferência mais "didática" em termos de que o "intelectual deve guiar as massas" para ceder a uma “espontaneidade" popular, marcada pelas contradições. Encontramos esta sugestão nas análises de Jean Claude Bernardet em seu livro Cineastas e Imagens do Povo. ${ }^{51}$

Finalmente, no que designamos como bloco 6 da nossa análise, como sendo "rupturas", ocorre uma terceira e definitiva conversa entre pai e filho, após os eventos da greve colocarem um contra o outro. Na verdade, Tião fura a greve e Otávio é preso. Novamente, cria-se uma expectativa, um suspense em relação ao tipo de conversa que ocorrerá entre pai e filho após a atitude de Tião. Antes, porém, seguem-se sequências que alternam esta cena no portão da fábrica envolvendo Otávio e Tião, e cenas de repressão policial aos grevistas, em que Maria é ferida e hospitalizada. A radicalização da repressão policial, é acompanhada por um desfecho em que as duas conversas ocorridas entre Tião e Maria e Tião e Otávio, são marcadas pela agressividade, pela

\footnotetext{
${ }^{51}$ BERNARDET, Jean-Claude. Cineastas e Imagens do Povo. Companhia das Letras, São Paulo, 2010. Especialmente, na referência ao documentário $A B C$ da Greve (1979) do próprio Leon Hirszman, onde o autor sugere que se trata de uma captação da greve fora dos portões da fábrica, sem discurso acadêmico dominante.
} 
emotividade e pelas "rupturas". Aparece, nesta altura do filme, o argumento de que as duas opções em jogo até aqui, quase simétricas em termos de importância, são incompatíveis e insustentáveis. A partir dessa "ruptura" percebemos que o filme, em seu desfecho, adota a perspectiva de Otávio que já analisamos no capitulo anterior, na cena dos feijões e nas outras duas sequências que formam uma conclusão.

Com Otávio e Tião ocorre o mesmo, ficando claro que o rompimento entre eles não resolve as diferenças, mas apenas colocam-se novas prioridades. Tião parte para a ação, Otávio aceita resignado a necessidade de continuar mesmo lamentando a morte de Bráulio (e por extensão, a morte de uma corrente mais moderada do movimento operário?), e a cena final da passeata cortejo fúnebre de Bráulio não deixa de destacar a escolha do cineasta pela ação coletiva. E por isso, podemos inferir que apesar de não pactuar com um engajamento explícito com a greve, considerando o que acontecia desde 1979 no ABC em São Paulo, onde o filme é produzido, não podemos descartar uma adesão à perspectiva comunista de Otávio sobre a precedência da ação coletiva diante da alternativa de ação individualista de Tião.

Ao investigarmos a polarização criada em torno dos personagens Otávio e Tião, acreditamos elucidar, de que se tratam de dois caminhos, na verdade.

Mas como já discutimos linhas atrás, não se trata apenas de um cenário que contextualiza historicamente o drama individual dos protagonistas. O espaço urbano presente no filme, contextualiza, mas também remete ao imaginário coletivo acerca da verdadeira condição de vida da maioria dos brasileiros e das contradições do "milagre econômico" expressas na expectativa de ascensão social de Tião e na marginalidade de sujeitos anônimos retratados durante o filme. Apesar de não terem um papel especifico no drama principal, "incomodam" pela sua presença em várias cenas, como por exemplo, o violeiro que frequenta o bar do Alípio, o próprio Alípio, o jovem negro 
assassinado por policiais no início do filme, o assaltante que atira em Jurandir (pressupondo um desempregado desesperado com a situação desalentadora em que se encontra), Jurandir operário da construção civil e assassinado, o atendente do trailer onde Otávio e os companheiros bebem sua cachaça.

Quando consideramos estes elementos resumidamente citados aqui, e procuramos afirmar qual é a "mensagem" do filme, temos que investigar mais do que a mera conclusão a que somos levados pela narrativa fílmica. Não se trata de um filme hermético, pelo contrário, o drama que assistimos é simplificado e chegamos a nossas conclusões mais óbvias. Mas, parece que resta algo que permanece desarticulado com esse desfecho simplista. O discurso cinematográfico, que tomamos a liberdade de assim denominar, esconde ou articula, várias "brechas" interessantes, por onde o olhar um pouco mais atento pode "problematizar".

Vamos nos concentrar agora, no aspecto mais didático de sequências que já analisamos no capítulo anterior, referentes ao personagem Bráulio e tratar da cena onde ocorre a verdadeira catarse do filme, que é a discussão entre Tião e Maria, com o rompimento do noivado e seus possíveis significados.

O personagem Bráulio é definido por Leon Hirszman como "o líder que é morto e se transforma num mártir popular e herói, inspirado em Santo Dias, ativista sindical assassinado em 1980." A sequência do assassinato de Bráulio, está no que denominamos de bloco 7 da análise, num trecho composto por 18 planos. No primeiro plano desta sequência, estamos de volta na rua em frente ao portão da fábrica onde há movimento de operários e policiais. Bráulio foi até o local conter o ímpeto de Sartini, temendo pelo companheiro que parece não ter noção do perigo que corre ao enfrentar a repressão policial. Os operários formam um cordão humano, com Sartini empurrando a turma para cima dos policiais e Bráulio tentando evitar o confronto, pedindo para que 
todos se dispersassem. Um carro estaciona no local, e assistimos a dois policiais a paisana descerem armados. Um deles aponta o revólver para Bráulio, após ouvir do outro policial “O crioulo! É o crioulo!”, e realiza dois disparos. Bráulio cai de joelhos, amparado por Sartini, enquanto a multidão se dispersa assustada. A morte de Bráulio se constitui como uma cena extremamente "trágica", que alterna com a partida de Tião no ônibus, sozinho, carregando sua mala.

Bráulio também aparece com destaque em duas outras cenas que faremos referência agora. Ele impede que os operários grevistas espanquem Tião, que sai da fábrica para ver o estado físico da namorada agredida por policial durante tentativa de piquete. Esta breve cena ocorre antes do acerto de contas entre Maria e Tião, quando Bráulio intervém a favor de Tião. Bráulio repudia a violência contra Tião, chamando atitude dos operários agressores de "arruaça" e corrigindo a perspectiva deles sobre a necessidade de reunir-se no sindicato, de fazer movimento ordeiro. Bráulio ainda afirma sobre Tião que "ele não é nosso inimigo! Nosso inimigo é a repressão que arrebenta com a gente! Parem de correr atrás de um bunda mole como ele, que só pensa em si mesmo! E vamos nos reunir no sindicato!"

É a mesma perspectiva que pode até estar ligada a Otávio, carregando em si mesmos o heroísmo de sujeitos da história, resistindo à opressão e à repressão da ditadura militar, e à ignorância da sociedade capitalista, e dos operários que ainda não foram convencidos da realidade da sua condição de classe, e de que não se consegue nada sem mobilização coletiva. Otávio e Braúlio possuem traços de heróis do realismo soviético, mas na mesma proporção que Leon Hirszman atribuiu a outros aspectos como o maniqueísmo entre Tião e Otávio, por exemplo. Ou seja, há uma certa complexidade animando a constituição dos personagens, que não são "fechados". Parece que a única 
regra de composição adotada para todo o filme é a abertura, como num processo de formação que não se conclui.

Aqui, também está operando, a capacidade que Leon Hirszman demonstrou para desconstruir o sentido canônico do melodrama, nas relações Tião-Maria, Tião-Otávio, Otávio-Sartini, entendido como princípio formal da pedagogia da emoção. No caso, Braúlio divide com Otávio também essa função de apontar o melhor caminho, aquele aprendido a duras penas pelos militantes mais veteranos. Há uma função pedagógica na sua ação dramática que recoloca o sentido original que tende a perder-se nas antinomias dos conflitos ideológicos entre Otávio e Tião e Otávio e Sartini. O cinema de autor, construindo pela perspectiva emprestada a Otávio e Bráulio, o ponto de vista de Leon Hirszman sobre a questão operária no ABC.

A outra cena em que Bráulio redireciona nosso olhar para a perspectiva correta, é extremamente didática em seu desenvolvimento visual e em termos de diálogo. É a sequência que antecede a greve, segundo Bráulio "ensinada no golpe", em que Sartini jogava bocha com outros operários supostamente favoráveis ao seu ponto de vista. Sartini não representa uma perspectiva específica porque é enquadrado pelas outras três perspectivas como antagonista, ou mais precisamente, na de Otávio, na de Tião e na que é proveniente da "instância narrativa". Sartini e Otávio quase chegam às vias de fato, por causa de suas divergências quanto ao comportamento leviano de Tião em denunciar os operários envolvidos com a greve, para a gerência da fábrica. Bráulio defende que "a questão é política! Não é questão pessoal, é política! E arranca uma bola de bocha da mão de Sartini, entregando-a a outro companheiro que estava ali apartando a briga também.

Finalmente, trataremos do momento de catarse do filme concentrando a análise em Maria, personagem que, para além de seu papel dramático de companheira de Tião, 
que muda durante o processo que se encaminham para a greve, assumindo maior consciência política e solidariedade de classe, também demonstra uma função didática importante ao "desmascarar" a ideologia de Tião perante o espectador.

Maria não seria exatamente, uma feminista. Mas há alguns traços, que poderiam sugerir, pelo menos duas características presentes em sua psicologia. O fato de não permitir que Tião a controlasse quando ela manifestou o desejo de participar dos piquetes de greve e o teor da bronca que ela despeja sobre Tião na cena do rompimento do noivado. Maria possui uma militância feminista e marxista, ao mesmo tempo.

“(...) O fato de as mulheres terem sua participação na vida social determinada por três elementos qualitativamente distintos - sexo, classe e etnia/raça - explica em parte as fraquezas e os limites dos diversos movimentos femininos que a história conhece. Todas as mulheres sofrem a mesma discriminação sexual e têm, nesse sentido, reivindicações comuns. Mas a impossibilidade de transformar essas reivindicações numa plataforma única, de sensibilizar todas as mulheres para essa plataforma, está dada pelas contradições situadas no âmbito da divisão de classes. A análise das plataformas reivindicativas de diversas correntes norte-americanas e européias mostra não somente concepções distintas no que se refere às causas da opressão da mulher, mas, principalmente, que as reivindicações feitas dependem muito do grau de desenvolvimento econômico e social de cada sociedade. Assim, se as feministas em geral defendem o fim dos 'fundamentalismos', as feministas socialistas e comunistas também são contra o fundamentalismo do mercado e do capital. " $(p .367)^{52}$

$\mathrm{Na}$ diferenciação por Maria Lygia Quartim de Moraes, existem feministas em geral e feministas comunistas e socialistas, cujas diferenças estão em que estas últimas, incluem em sua plataforma de reinvidicações "o fundamentalismo do mercado e do

\footnotetext{
52 MORAES, Maria Lygia Quartim de. O Encontro Marxismo-Feminismo no Brasil. In: História do Marxismo no Brasil - Partidos e Movimentos após os anos 1960 - vol.6. (pp.341-374)
} 
capital.” Nesse sentido estrito, Maria se comportaria como feminista comunista, ou em termos alegóricos, na correspondência com o contexto social e político enquadrado no filme de Leon Hirszman, como recuperação da dignidade do PCB diante da confusão ideológica reinante no meio operário brasileiro. Tião encarna essa confusão ideológica, tida por ele como manutenção do status quo dominante, que discrimina entre homens e mulheres, mesmo no meio operário. A força da interpretação de Maria por Bete Mendes, está na dialética entre militância real da atriz e novamente a nuance de herói do realismo soviético, que nunca hesita em afirmar a opção coletiva contra as opções individualizantes.

Na conversa entre Tião e Maria, no bloco 6, planos 1 a 23 de uma sequência de 43 planos, a tensão atinge o auge, e podemos assinalar como o momento de catarse do filme. Maria argumenta que Tião paga um preço muito alto para sustentar as suas convicções pessoais de ascensão social, e que a falta de solidariedade com o pai que estava sendo preso, demonstra falta de caráter. O tom é mais pesado do que na peça, que conduz a fala final de Maria para a acusação de que Tião agia por covardia. Maria é em certo sentido, uma versão menos complexa da Madalena de São Bernardo. E Tião, uma caricatura do Paulo Honório de São Bernardo, em que o self made man é confrontado por uma consciência crítica que ele não pode comprar ${ }^{53}$. Além disso, Tião se defende, afirmando não ter agido por covardia, quando interpelado pelo pai na última conversa entre pai e filho que o filme apresenta. Os planos 24 a 34 desta sequência, dez planos onde Otávio "rompe" o relacionamento com Tião, quando desmascarou o sujeito "reacionário" no comportamento do filho. Tião parece impregnado de uma "alienação" congênita, lutando contra o pai e a namorada para afirmar sua convicção de vencer na vida. O tema da alienação está presente em toda a filmografia de Leon Hirszman desde

\footnotetext{
${ }^{53}$ CARDOSO, Maurício. História e Cinema: Um estudo de São Bernardo (Leon Hirszman, 1972). Dissertação de Mestrado. Janeiro de 2002.
} 
Pedreira de São Diogo, A Falecida, Garota de Ipanema, São Bernardo, Eles não usam

blacktie e Imagens do Inconsciente (inacabado). Tião se encaixa nesse repertório de pessoa "alienada" em termos psicológicos e sociais.

Parece que estamos aqui, no auge da conclusão do filme, e no seu principal argumento que resolve a tensão com o rompimento, sem vitoriosos. Mas, de qualquer maneira, a perspectiva de Otávio e Maria prevalecem, conferindo a estes, a primazia na lição que o filme pode encerrar enquanto sustenta a aposta de comunicação com o público, de desmascaramento da ideologia burguesa presente nos meios de comunicação de massa. Revelando que a catarse também pode se dar numa aposta na outra face da moeda do individualismo que marca o universo das relações sociais capitalistas. A quebra das expectativas de reconciliações e final feliz, é em si, uma crítica aos produtos melodramáticos da indústria cultural brasileira.

Nesse sentido, o filme transita pela forma do drama e do melodrama deslocando certos pressupostos canônicos, como o certo e o errado, mocinhos e vilões, final feliz, etc., perseguindo o objetivo de inserir-se na luta operária muito mais do que apenas representá-la. Por isso, a representação em si, demonstra o resultado que já apontamos, de certa "frouxidão" na caracterização ideológica dos personagens como temos procurado demonstrar ao longo da dissertação.

Otávio e Tião hesitam no momento crucial, o que retira-lhes, agora, aquelas nuances de heróis, propriamente dito. Otávio, no momento crucial, na sequência em que Tião fura a greve, demonstra certa hesitação, equilibrando aquela característica acentuada de realismo soviético. Esse comportamento rendeu-lhe críticas de Maurício Segall na sua análise de Eles não usam blacktie, como se Otávio fosse representante da Frente Única, e como tal um sindicalista pelego. Enquanto fazem piquete, Sartini, que aos olhos do próprio Maurício Segall seria representante do Novo Sindicalismo, 
interpela os operários de maneira mais exaltada, sendo repreendido por Otávio. Em breves sequências no bloco 2, no bloco 3 e no bloco 4, Otávio e Sartini discutem demonstrando suas divergências quanto ao encaminhamento da greve. No bloco 2, início do filme, portanto, Otávio e Bráulio contrariam Sartini no vestiário da fábrica ao saberem das demissões de companheiros engajados no movimento. Eles propõem a estratégia de trabalhar, organizando a greve pacientemente. Sartini desejava parar a turma imediatamente, como protesto pelas demissões injustas. O telespectador saberá um pouco adiante que as demissões foram provocadas por Jesuíno e que em outra sequência, no bloco 3, a demissão de Sartini por sua vez, deve ser atribuída às delações de Tião para a direção da fábrica. Há um esquema de suborno, denunciando um certo tipo de "clientelismo" à brasileira na atitude de Jesuíno e Tião para serem reconhecidos pela direção da fábrica e promovidos. O esquema é esclarecido pelo próprio Jesuíno numa cena em que ele e Tião almoçam no refeitório da fábrica nos planos 1 a 16, no bloco 3. Somos conduzidos para o espaço da fábrica, um conjunto de cenas curtas sobre a linha de montagem, Tião é chamado ao DP por um funcionário e logo a seguir estamos no refeitório. No refeitório, Jesuíno expõe as razões para colaborar com a direção da fábrica. O seu argumento é o de que a única saída para quem quer subir na vida é "dançar conforme a música", e no caso deles, é cooperar com a fábrica denunciando os operários envolvidos com os preparativos para a greve. Tião hesita diante da "proposta" de Jesuíno, talvez com escrúpulos pela "imoralidade" da atitude. Por fim, acaba consentindo com Jesuíno, quando Sartini critica a passividade dos operários diante das demissões injustas que estão sendo praticadas na fábrica. O resultado é a demissão de Sartini, que se depara novamente com as resistências de Otávio e Bráulio contra a precipitação da greve. Com isso, pretendo demonstrar a hesitação de Otávio em abraçar a greve com entusiasmo. Tião, por sua vez, também não 
encarna o protótipo do herói positivo, porque hesita em aceitar o caminho proposto por Jesuíno, insistindo em sua linha de ação numa justificativa para furar a greve por convicção. Nesse aparente impasse em que os blocos 2, 3 e 4 parecem arrastar Otávio e Tião, podemos perceber mais hesitação do que propósitos claramente definidos. Como se fossem realmente arrastados pelas circunstâncias, reagindo aos lugares comuns ou fugindo das demarcações que um modelo normativo de conduta poderia supor. Esse procedimento adotado pela montagem sugere que procurou-se retirar o sentimento de culpa dos ombros dos protagonistas. O que isso poderia representar é a "intenção" de frisar que os personagens do drama agem como as pessoas num processo social verdadeiro. A pretensão de que o filme se insere no processo social, do papel social do artista, do papel do realismo crítico como forma de desvendar a realidade social brasileira para que a comunicação com o público, se torne, em última instância uma intervenção problematizadora das formas canônicas utilizadas na "formação" cultural dos espectadores. 


\section{CONCLUSÃO}

O espaço presente na composição do filme é um dos pontos fortes da transposição da peça teatral para o cinema. Na peça original Eles não usam blacktie (1957), tendo em vista a sugestão do texto de Gianfrancesco Guarnieri sobre a caracterização do espaço social de atuação dos personagens do drama, percebemos que tudo se passa no ambiente doméstico da casa de Otávio. Todo o restante, em termos espaciais, é imaginação provocada pelas falas dos atores que contracenam numa arena cercada pela plateia. Não há mudanças radicais do cenário, apenas sugestão do que ocorre em outro lugar e passa a ser tema de diálogos, como a própria greve. Não há, em outras palavras, uma dramatização da greve nem de outros ambientes como a fábrica ou o bar. Nesse sentido, o ambiente social, na peça teatral, propriamente dito, é apenas cenário.

No filme Eles não usam blacktie (1981) o espaço social é um dos argumentos com que a narrativa foi construída, conferindo significados que extrapolam a sua condição de mero cenário para a dramatização. Consideramos que o espaço urbano se insere como parte estrutural do modo de narrar o drama operário.

Partimos da hipótese de que o filme é político, de esquerda, adota uma visão que valoriza a participação popular, mas que não é normativo, e por isso, utiliza uma forma que se caracteriza pelas ambiguidades entre melodrama e realismo crítico.

Começaremos pelo ambiente do bar do Alípio, presente na encenação desde as primeiras cenas quando Tião e Maria retornam de ônibus para o bairro e observam a repressão policial aos seus frequentadores. O bar como espaço de socialização dos operários, mas também como referência ao costume de ingerir bebida alcoólica presente em todo o desenrolar do filme. Os primeiros 20 planos do bloco 2, domingo de manhã, 
são a descrição mais detalhada deste ambiente frequentado pelos protagonistas do filme. Balcão, garrafas arrumadas nas prateleiras, engradados vazios amontoados num canto, mesa de bilhar, e um elemento da cultura popular num grupo inusitado formado pelo violeiro nordestino anônimo, presente em várias cenas do filme, e companheiros músicos produzindo o fundo musical da sequência a que nos referimos.

A presença dos músicos confere ao lugar uma confirmação de que o bar é um ambiente de socialização dos operários segundo a concepção utilizada no filme. Frequentar o bar é parte do lazer dos operários e um elemento sociológico descritivo do comportamento social dos operários. Não parece casual essa caracterização da importância do ambiente social sobre os indivíduos, quando comparamos com o material filmado para o documentário $A B C$ da Greve de 1979, também de Leon Hirszman. Esse documentário forneceu embasamento audiovisual para que, em nossa concepção, os ambientes do filme não sejam apenas decorativos, mas que funcionem como peças da engrenagem discursiva do enredo. Os espaços ou ambientes sociais descritos no filme parecem-nos importantes, sobretudo, como parte do argumento utilizado para justificar as ações dos personagens. A sociedade brasileira no período da ditadura militar é um elemento forte no discurso de Otávio para justificar a sua "cautela" diante da euforia de Sartini e da apatia política de Tião. Tanto Sartini quanto Tião seriam os mais jovens, a "juventude" que vive após o período mais repressivo da ditadura militar brasileira (LNS, AI-5,etc.), e acreditam que estão inventando a roda.

O bar é "estilizado" num esquema do ambiente social do filme, rivalizando em importância com a casa e a fábrica. Há um revezamento desses três ambientes, que reforçam o sentido de rotina adotado pela narrativa que também se conduz demarcando a passagem do tempo pelos dias da semana. O filme é, rigorosamente falando, a passagem de duas semanas entre a revelação da gravidez de Maria, o anúncio de 
noivado e a greve dos operários da fábrica onde todos trabalhavam, com exceção de Romana e os demais figurantes. Esse é um aspecto de crônica social que o filme mantém como registro do cotidiano dos operários que se aproximam da greve, como o momento em que a sua verdadeira identidade como "classe social" se manifesta. A demarcação que os espaços e o tempo que compõem o cotidiano dos operários revela é o naturalismo próprio ao gênero melodrama, componentes essenciais na composição do filme junto com o tom sentimental das cenas.

Há uma cena intercalada entre a segunda discussão entre Otávio e Tião, que se inicia numa manhã com Otávio tomando café e observando a paisagem do bairro da porta de sua casa, e a reconciliação entre pai e filho acontece. É a manhã seguinte à discussão e que apresenta todas as características que tentamos descrever anteriormente. Otávio toma café, lançando à paisagem do bairro um olhar pensativo, uma música instrumental preenche o ambiente, produzindo uma cena melancólica. Tião cumprimenta o pai, e a câmera alterna a perspectiva de fora para Otávio na porta com a xícara de café na mão e dentro do ambiente doméstico, como se fosse a visão de Tião focando o pai e a paisagem além dele. É uma cena curta, que apresenta um instante da experiência cotidiana da família, como aliás outras cenas também fazem referência como a cena em que Romana estende roupas no varal e Tião toma seu café da manhã. São, geralmente, cenas de refeições, e pequenas conversas sentimentais. Nesses momentos retratados como corriqueiros ou banais, a crônica da pobreza da família operária é metáfora para a condição de vida de milhares de brasileiros moradores das periferias de uma grande cidade. Dessa maneira o filme vai acumulando cenas representativas de crônica do cotidiano operário. Nada no filme parece solto, à toa, ou sem ligação com a temática da vida operária. A maneira como a montagem parece fazer uso do naturalismo das cenas que descrevemos, é que nos chama atenção. Uma certa 
instrumentalização de cenas em que espaço e tempo cotidianos servem ao propósito didático de encaixar a relação entre Otávio e Tião. Porque o pai deveria agir daquela maneira e o filho não deveria agir de outra maneira, parecem decorrentes dessa apresentação naturalista do cotidiano operário. O elemento de realismo crítico ao nosso ver repousa no princípio formal que organiza o filme como pedagogia para o espectador na greve com os operários.

Assim como o bar relaciona-se ao lazer mas contém certa dose de alienação social, a residência é o lugar do repouso, das conversas sobre a experiência do trabalho, ponto de partida para um novo dia a cada nova manhã. Há duas imagens diferentes do lar apresentadas no filme, uma da família de Otávio e Romana e outra da casa e da família de Maria. O contraponto é evidente entre uma casa operária onde se discute política como na casa de Otávio, e uma casa onde o chefe da família é alcoólatra e desempregado, trabalhador da construção civil. A conotação da bebida alcoólica aqui é diferente daquela de hábito operário de beber, sendo negativa porque destrutiva dos laços familiares, viciante e trágica. Outra faceta da alienação social em que vive mergulhada a grande massa trabalhadora brasileira, a bebedeira para escapar da realidade. Utilizo como parâmetro uma cena em que, ainda na bloco 1 da análise, quando Maria e Tião se despedem em frente à casa dela, há forte conotação ao alcoolismo, à televisão e a desarmonia familiar. Jurandir, pai de Maria, visivelmente bêbado, insulta Maria por ter chegado tarde em casa, discute com a esposa doente. Maria afirma "não ver a hora de se mandar dali", expressando sua revolta contra o ambiente doméstico opressivo. Há uma contradição aparente entre o bar estilizado em que músicos retiram do ambiente o lado negativo dos viciados em álcool, e a casa de Maria cujo ambiente doméstico é desestabilizado exatamente pelo consumo excessivo de álcool. Na verdade, são apenas traços do cotidiano dos pobres que somam-se na 
crônica da vida na periferia e que seguem a mesma estrutura da polarização entre Otávio e Tião. É como se do cotidiano da pobreza em que vivem os operários, houvesse o equilíbrio entre fatores contraditórios, do meio dos quais a polarização entre Otávio e Tião não fugisse à mesma regra.

O meio social retira o excesso de culpa dos protagonistas, que parecem ser levados à ação contra a própria vontade. Tião insiste nisso quando se justifica perante o pai e a namorada, após ter furado a greve, que entende e compartilha do mesmo sofrimento de todos, mas que agiu como que "forçado pelas circunstâncias". Tião afirma que não agiu por "covardia", mas que priorizou outra perspectiva de ação aberta para ele, pelo ponto de vista de Jesuíno. A ascensão social se faz pelo "clientelismo" e não pelo merecimento, e se faz individualmente, não coletivamente. Esse imperativo é social, não foi inventado por Tião. Mas o que torna Tião condenável do ponto de vista ético, é exatamente a sua covardia, ao posicionar-se a favor do sistema e da máquina repressiva que o sustenta. Pelo menos da perspectiva que somos induzidos a assumir pela instância narrativa, Tião "poderia" ter protegido a namorada e o pai no momento crucial. Há uma mudança de foco, assim como tentei demonstrar quando tratamos do aumento gradativo da tensão nas conversas entre pai e filho, o tratamento de igualdade entre as opções individual e coletiva desparece ao final do filme. Não há igualdade, uma vez que contra a força não há argumentos, e os personagens respondem de forma passional assumindo categoricamente suas posições até então defendidas de maneira equilibrada. Desaparece o equilíbrio e a simetria entre as razões apresentadas por pai e filho e somos forçados, assim como os personagens da narrativa a assumir posição. Por isso cresce a tensão percebida nas conversas entre Otávio e Tião, virando discussão política. E cresce a diferença entre as opções políticas, e a "hesitação" de Otávio diante de Sartini e de Tião diante de Jesuíno, se transformam em "radicalismo". Baixada a 
poeira das discussões políticas acaloradas, restam as cinzas expressas na cena dos feijões e desaparece a perspectiva de Tião. O desfecho do filme, como já adiantamos adota o ponto de vista de Otávio e assim, demonstra a preferência do cineasta pela opção coletiva e feita de pequenos avanços. A família incorpora as contradições da luta política, repercutindo-se nas outra esferas sociais e não apenas recebendo influências destas, passivamente.

É no ambiente da fábrica que se estabelece o domínio completo de Otávio, já que no lar as discussões igualam Tião e Otávio como concorrentes, e neste outro âmbito Tião renunciou à participar. Tião não participa das reuniões do sindicato o que liberta ainda mais a capacidade pedagógica de Otávio como protagonista com os companheiros de trabalho e com o espectador ensinando como se faz a greve. Não foi dramatizada nenhuma reunião do sindicato, mas há um aumento gradativo da tensão nas discussões entre Otávio e Sartini. Seguindo o mesmo modelo das discussões entre Otávio e Tião, presenciamos encontros fora dos portões da fábrica entre os operários engajados com a greve.

Logo no início do filme, no que consideramos bloco 2, na saída de uma destas reuniões do sindicato, domingo à noite, após uma cena de amor entre Tião e Maria, Otávio, Bráulio e Sartini discutem sobre o encaminhamento da greve. Esta apresentação dos operários saindo do sindicato cria um contraponto com a "alienação" de Tião (apesar de tratar-se de uma cena de amor), porque opõe duas imagens postas lado a lado propositalmente. A comparação se estabelece entre Otávio e Tião, mas no interior da cena também podemos perceber uma outra "polarização", agora, entre Otávio e Sartini. Otávio discursa contra o operário "porra-louca", opondo a decisão de greve tomada pelo pequeno contingente de operários sindicalizados na fábrica Santa Marta (título da fábrica no filme) e o total da categoria dos metalúrgicos (referência aos sindicatos do 
$\mathrm{ABC}$ ). Sartini responde com o termo "bunda-mole", e que o sindicato está na mão de um pelego (referência ao Joaquinzão, na época líder sindical do $\mathrm{ABC}$ combatido por Lula e outras lideranças insatisfeitas com o peleguismo). Utilizamos aqui a contextualização política feita por Maurício Segall no seu referido artigo sobre o filme Eles não usam blacktie.

Há dois polos de tensão ideológica que interagem produzindo duas situações onde analisamos a constante reiteração do recurso retórico da comparação e da "falsa equivalência" entre os elementos postos em comparação. Num primeiro polo de comparação que já analisamos até aqui, Otávio e Tião apresentam um conflito que pode ser definido como o discurso engajado contra o discurso alienado. Já na outra polarização em andamento, no âmbito da fábrica, Otávio e Sartini discursam de dentro do movimento grevista, disputando alternativas de ação imediata, simbolizando as correntes políticas em jogo. Ao final do bloco 3, após o velório de Jurandir, pai de Maria, Bráulio procura Otávio em sua casa. Bráulio anuncia ao companheiro que em sua ausência, a assembleia votou favoravelmente à greve. "Segunda-feira greve geral!" é a expressão usada por Bráulio para se referir ao que ficou decidido em assembléia, e corresponde a um dos possíveis títulos do filme. A narrativa continua demarcando a passagem do tempo pelo cotidiano da família de Otávio, e a montagem vai alternando os espaços da casa, da rua e da fábrica.

No início do bloco 4, começam os preparativos para a greve e a sequência inicia-se, num campo de futebol onde ocorre uma partida numa manhã ensolarada de domingo. Sartini jogava bocha com operários, quando é interrompido pelos gritos de Otávio, seguido de perto por Bráulio seu fiel escudeiro. Otávio ironiza afirmando que Sartini teria "sumido" pra não se encontrar com ele. Sartini devolve a ironia frisando que agora é "se preparar para o pau...", utilizando uma expressão popular "agora, Inês é 
morta" referindo-se à greve do dia seguinte. Otávio responde dizendo que a greve foi “precipitada, que a repressão vai baixar na fábrica e que não houve preparativos de greve, suficientes", que a greve vai ser um "fracasso" e que não se pode comparar uma "fabricazinha como a Santa Marta com o conjunto de fábricas do ABC Paulista." O argumento de Otávio é um argumento recorrente nas falas dele e de Bráulio, sobre a falta de organização dos operários, pelo menos no que se refere ao suposto raio de ação aberto para eles. Aqui há outra ambiguidade, porque Otávio compara a desorganização e o despreparo deles com o exemplo das greves do ABC Paulista. Talvez prevaleça aqui, uma comparação para diferenciar as coisas para o espectador, muito mais do que mero derrotismo em relação à greve. Para demonstrar que o filme não é uma representação daquelas greves tão conhecidas à época das filmagens. O certo é que nesse momento do filme, a discussão se volta para a suspeita de que Tião delatou Sartini para a direção da fábrica, ocasionando a sua demissão. Otávio explode e ofende Sartini, afirmando que ele provocou a greve para "vingar-se" por ter sido demitido. Quem chama os companheiros para a razão e "ensina" algo sobre a greve, é Bráulio que argumenta que “todos devem esfriar a cabeça, tomar um negocinho no bar, e tratar de política, não de assuntos pessoais." Esse é o ponto de maior tensão no que consideramos como polarização entre Otávio e Sartini. Diferentemente da primeira polarização que frisamos como sendo de ruptura, nesta segunda forma de tensão ideológica, o resultado é a conciliação.

Por fim, em termos de construção de uma imagem "sedutora" com forte apelo emocional, e que completaria as três últimas sequências que consideramos fundamentais para o entendimento do filme, vamos comentar brevemente a análise sobre a passeatacortejo de Bráulio. A imagem da massa popular tomando as ruas é sempre significativa para qualquer movimento social de caráter contestatório, e podemos perceber pelos 
menos dois grupos participantes da passeata-cortejo de Bráulio no filme, os operários e os católicos. Complementando a percepção visual, há um contingente grande de anônimos que engrossa a manifestação. O que gostaríamos de frisar nesse epílogo do filme, em termos de conteúdo, é o apoio à greve e a maneira como todos os personagens, com exceção de Tião e Jesuíno, demonstram solidariedade. Essa imagem completa o sentido geral do filme, cujo elemento do espaço urbano joga um papel decisivo para desfazer uma impressão que as falas finais de Tião externaram muito bem, quando ele discutia com Maria "Você tá meio-maluca aí como todo mundo! O que foi, hein? Tá todo mundo ficando doido?" Com isso, reforçamos que o tratamento do filme com as opções político-ideológicas defendidas por Otávio e Tião, não foi apenas o desmascaramento do certo e do errado. A pedagogia do filme funciona com a estratégia de seduzir, de emocionar com o propósito de colocar para o espectador as contradições de maneira didática.

Em termos de forma, é uma cena que se sobrepõe aos acertos de conta entre Otávio e Tião e Maria e Tião, demonstrando um tratamento poético que procura elevar os personagens individuais do drama a um personagem coletivo, aproximando operários e o "povo" contra o inimigo comum de todos os movimentos sociais. É pelo princípio formal da pedagogia da emoção que podemos compreender o jogo dos elementos da forma e do conteúdo, na construção da imagem de questões que estavam na ordem do dia como a "democrática" e a "operária", e o estilo da montagem do drama com falas devidamente arranjadas com esse propósito de comunicar idéias.

As fontes

A pesquisa iniciou-se no acervo Leon Hirszman no Arquivo Edgar Leuenroth (AEL), localizado no Instituto de filosofia e ciências humanas da UNICAMP. Os 
prontuários que considerei mais relevantes para a pesquisa foram os que continham artigos de jornais sobre o filme, os roteiros, inclusive da segunda versão do roteiro do filme que deveria chamar-se "Segunda-feira, greve geral!" com uma introdução que sugeria uma abordagem mais documental para o filme. Há muitas anotações do próprio Leon Hirszman em diversos papéis avulsos e em algumas páginas dos roteiros que apontam para os significados que cada personagem do drama deveria incorporar.

Procurei concentrar a pesquisa nos possíveis significados atribuídos ao filme no período de seu lançamento e confrontar esse material com as entrevistas do cineasta Leon Hirszman, procurando estabelecer alguns parâmetros que me auxiliassem no trabalho de análise do filme. Há contradições entre certas abordagens do filme, que ora é considerado como "neorealismo", ora como melodrama e também quanto ao fato de tratar-se de filme popular ou de filme político. As vezes os termos popular e político aparecem como sinônimos, as vezes são até opostos. Sendo basicamente, críticas favoráveis ao filme de Leon Hirszman. Com exceção do artigo de Maurício Segall, Blacktie, mistificando como antigamente.

O próprio filme é fonte de pesquisa e as diversas interpretações na imprensa precisam ser confrontadas com o filme, para esclarecer as diferenças entre o que se escreveu a respeito do filme e o que está realmente concretizado enquanto obra cinematográfica. O processo de produção do filme é história em pelo menos dois sentidos: como produto que apresenta uma visão da história e como produto da própria história vivida como experiência particular e como experiência coletiva.

História e Cinema: um estudo de São Bernardo, dissertação de mestrado de Maurício Cardoso, Uma História do Brasil recente nas minisséries da rede globo, tese de doutorado de Monica Almeida Kornis e Coração Civil: Arte, resistência e lutas 
culturais durante o regime militar brasileiro (1964-1980), tese de livre-docência de Marcos Napolitano foram trabalhos que contribuíram para a compreensão de questões referentes ao estudo do cinema e do contexto cultural brasileiro, muito próximos das questões que animaram a presente pesquisa.

De maneira geral, a bibliografia específica sobre o filme é um pouco escassa, mas em contrapartida, o projeto da cinemateca brasileira de restauração da filmografia de Leon Hirszman é uma fonte riquíssima de pesquisa sobre o cineasta. A trajetória do cinema feito por Leon Hirszman, pode contribuir para discernirmos certos temas recorrentes em seu trabalho que divide-se basicamente em documentários e ficções.

A pedreira de São Diogo de 1962, é um curta que compõe Cinco vezes favela, cuja perspectiva é otimista em relação à força dos movimentos populares reivindicatórios. Maioria Absoluta de 1964, produzido pelo CPC da UNE e Minoria Absoluta que foi interrompido são documentários. A Falecida de 1965 e Garota de Ipanema de 1967, são ficções cujo tema é a alienação da classe média. Há uma temática de cultura popular nos documentários Nelson Cavaquinho (1967), Cantos de trabalho no campo - mutirão (1975), Partido Alto (1976/1982), Cantos de trabalho no campo cacau (1978), Cantos de Trabalho no campo- cana-de-açucar (1978), Rio, Carnaval da Vida (1978).

São Bernardo de 1972, Eles não usam blacktie de 1981 e ABC da Greve de 1979/1989 são filmes em que o tema da realidade social brasileira é investigado. Imagens do Inconsciente de 1983/1986 sobre o trabalho da psiquiatra Nise da Silveira. De uma forma geral, a filmografia de Leon Hirszman trata do tema da "alienação" com vários enfoques. 
Particularmente, o documentário $\mathrm{ABC}$ da Greve mantém uma relação muito forte com Eles não usam blacktie, participando na construção do ambiente social e político do filme. O bar, a linha de montagem na fábrica, os piquetes de greve e a repressão policial, além do cotidiano operário, são transfigurações artísticas das vivências dos operários grevistas filmadas no documentário.

O Objeto e as Hipóteses

O objeto de estudo desta pesquisa é o filme Eles não usam blacktie de Leon Hirszman, considerando o que a narrativa do filme coloca como "problema", como o filme dialoga com o momento histórico e como a adaptação do roteiro da peça teatral para o cinema, é "história" porque sustenta uma visão da história contemporânea do Brasil e é uma tentativa de intervenção na realidade social.

O problema que procuro discutir está na forma em movimento do filme, ou no movimento do filme que produz a sua forma. Partimos da hipótese de que o filme é um melodrama, mas não um melodrama convencional. O tratamento dado aos elementos dramáticos do filme "problematiza" com a forma canônica do melodrama e sugere que há outros elementos participando da produção do filme, que não apenas reproduzem sentidos padronizados pelo gênero. Por outro lado, o filme não consegue se livrar totalmente de um certo maniqueísmo que empobrece as concepções político-ideológicas que poderiam resultar numa discussão mais aprofundada da realidade social brasileira.

Mesmo sem apresentar um grande diagnóstico da história do Brasil, o filme consegue matizar o maniqueísmo inerente ao melodrama conjugando o entretenimento de consumo cotidiano com a crítica do próprio cotidiano da família operária. A “questão operária" é diluída nas discussões entre os personagens principais, mas está presente no 
filme. Não é um filme sobre as greves do $\mathrm{ABC}$, porque não é nem uma versão dessas greves, mas um recorte em miniatura de uma greve numa fábrica menor de São Paulo, como se se tratasse de um espaço de reflexão sobre as greves em geral. Sobre as vicissitudes do processo real de construção de uma greve e dentro deste mesmo raciocínio, os conflitos familiares seriam miniaturas do conflito social brasileiro.

No documentário Maioria Absoluta e em São Bernardo, a apreensão do conflito social tem uma ambientação no meio rural. Em Eles não usam blacktie sobressai outra conjuntura, a do processo de desenvolvimento urbano e industrial, pela ótica do cineasta intelectual em sua relação com o movimento operário dos grevistas.

A pedagogia da emoção seria a estratégia de comunicação com um público mais amplo, uma forma de intervir na história, o princípio formal que organiza o filme. Nosso olhar não é dirigido apenas para as razões teóricas da greve, mas para os percalços da realidade de qualquer movimento reivindicatório numa sociedade capitalista. Acreditamos que a pedagogia da emoção é uma estratégia do cineasta para sensibilizar sobre a "questão operária".

Procuramos perceber o movimento próprio do filme, a partir de sua narrativa, de como ficção e história poderiam se fundir pela proximidade das greves do $\mathrm{ABC}$ e das filmagens do documentário $\mathrm{ABC}$ da Greve que forneceram importante material audiovisual para a "recriação" no ambiente do filme e dos personagens dramáticos. O estilo de direção de Leon Hirszman permite que os atores "reinventassem" os personagens, durante as filmagens, como no caso da personagem Maria que incorpora gradativamente a militância política da atriz Bete Mendes. No documentário ABC da Greve há uma cena em que o elenco de Eles não usam blacktie participa de uma festa no sindicato dos metalúrgicos, e que em outro documentário, Peões de Eduardo 
Coutinho, acompanhamos a mesma festa que contava com a presença das lideranças sindicais. Isso indica a proximidade da equipe de Leon Hirszman e do elenco do processo que mobilizava os metalúrgicos do $\mathrm{ABC}$ naquela conjuntura.

Mas, o filme não se constitui numa versão, mesmo que pessimista da Greve do ABC propriamente falando. O filme "problematiza" com a greve, com o processo de formação da consciência coletiva do movimento operário, com os percalços que a construção da organização operária enfrentava, e a derrota da greve representada no filme, na pequena fábrica Santa Marta, tem uma contrapartida na passeata-cortejo de Bráulio que homenageia o metalúrgico Santo Dias, assassinado por policial durante piquete da Greve de 1980, que aponta para a continuidade da luta.

Transparece uma "desilusão" talvez com a conjugação de forças que percebemos como efervescente no documentário $\mathrm{ABC}$ da Greve e que no Eles não usam blacktie, assume outra dimensão, menos eufórica. Representa, sem dúvida, mudança na conjuntura que se incorpora no Blacktie, e que demonstra mudança de enfoque e da visão histórica do filme. O próprio documentário $\mathrm{ABC}$ da Greve, é marcado por uma mudança de perspectiva histórica porque suas filmagens originais foram feitas em 1979 e sua finalização só ocorreu em 1989, dois anos após o falecimento de Leon Hirszman.

Procuramos nos afastar do entendimento do filme Eles não usam blacktie como ilustração do processo histórico das greves do ABC. A análise parte da concepção de que a matriz melodramática na estruturação da narrativa do filme é parecida com as produções televisivas para o consumo de massa, mas que a adoção do enfoque da pobreza em que se encontram mergulhados os operários e a "questão operária" confere ao filme uma tentativa de "educar o olhar" para a desconstrução da pedagogia 
demagógica dos produtos televisivos e a proposta de uma nova pedagogia com olhar crítico sobre a realidade social brasileira.

O filme apresenta como tentamos demonstrar pela análise, uma "tensão" constante com os procedimentos mais comuns em produções melodramáticas de consumo de massa, como o maniqueísmo, o final feliz, a proposta de uma nova moral ou ética. Quanto ao maniqueísmo, se o filme terminasse na expulsão de Tião de casa por Otávio, estaria confirmado o maniqueísmo, mas a extensão do desfecho do filme com o assassinato de Bráulio, a cena dos feijões e a passeata-cortejo são emblemáticos de que o direcionamento do nosso olhar deveria recair sobre outra problemática. De certa forma, a peça parece mais maniqueísta do que o filme.

A experiência de documentarista parece contribuir para os procedimentos utilizados para atualizar a peça de 1957 e não apenas adapta-la num novo contexto. A fusão de elementos documentais com elementos ficcionais confere ao filme um caráter de crônica do cotidiano operário. A reconstituição realista do cotidiano operário e das suas dificuldades concretas no universo diegético do filme, desfaz a ilusão de que a alienação do Tião é apenas conformismo ou apenas conformista enquanto espetáculo para ser contemplado. Existem componentes no filme que direcionam o olhar para uma reflexão sobre a condição do proletariado e a necessidade de intervir para mudar a história. Há duas éticas conflitantes: a do Tião e a do Otávio. A ênfase recai sobre a opção coletivista de Otávio, mas não tira certas razões do comportamento de Tião.

Esse procedimento de valorizar os detalhes em detrimento do conjunto nos parece recorrente em todo o filme, o que pode ser outro traço documental, de preocupação em captar o processo vivido, sem fechar as conclusões numa espécie de quadro estático. Por isso, o filme nos parece estruturado para "educar" o olhar para as 
dificuldades concretas da organização do movimento grevista, desviando-nos da contemplação do mero espetáculo que uma greve bem sucedida poderia provocar. 
BIBLIOGRAFIA

FONTES PRIMÁRIAS

FILMES

Eles não usam blacktie (1981)

Rio de Janeiro

Ficção 134'

Diretor: Leon Hirszman

Roteiro: Leon Hirszman e Gianfrascesco Guarnieri

Argumento: atualização da peça Eles não usam blacktie (1955) e G. Guarnieri

Fotografia: Lauro Escorel Filho

Montagem: Eduardo Escorel

Locações: Lapa / Vila Brasilândia

Música-tema: "Nóis não usa blequitais" de Adoniran Barbosa e Gianfrancesco

Guarnieri.

Produtora: Leon Hirszman produções

Elenco: Fernanda Montenegro, Gianfrancesco Guarnieri, Carlos Alberto Riccelli, Bete Mendes, Anselmo Vasconcelos, Milton Gonçalves, Lélia Abramo, Francisco Milani.

Documentário

ABC da Greve (1979-1989) 


\section{ARTIGOS DE JORNAIS}

Como farsa, filme repete saga trágica - Inácio Araújo

Ao contrário de Vidas Secas (1964), cinebiografia de Lula tem imagem acadêmica, linguagem arcaica e conformismo

Folha de SP, 1 de janeiro de 2010 (Ilustrada)

A classe operária entre o inferno e o paraíso -

Folha de SP, 28 de setembro de 1981 (Ilustrada)

Os homens do presidente - Tereza Novaes

Folha de SP, 26 de novembro de 2004 (Ilustrada)

Obras colocam homem comum no palco da grande história - José Geraldo Couto

Folha de SP, 26 de novembro de 2004 (Ilustrada)

A paixão bem temperada - Celso Amorim

Jornal do Brasil, 27 de setembro de 1987

"Eles não usam blacktie é possivelmente uma das maiores obras do neo-realismo".

AVELLAR, José Carlos. Letra e música de Graciliano Ramos interpretadas por Hirszman. Rio de Janeiro, Jornal do Brasil, 27 de jun.1972 .

COOPER, Carol. Dona Flor doesn't live here anymore. Nova York, Village Voice, 13 set. 1983 .

KAHNS, Cláudio \& MORAIS, Fernando. O espião de Deus. In: ABC da Greve (catálogo de apresentação do filme). São Paulo, Cinemateca Brasileira, 1991.

SALEM, Helena. Leon Hirszman. A volta (em clima de estreia) do premiadíssimo Eles não usam blacktie. Rio de janeiro, O Globo, 14 agho.1983.

SCHILD, Susana. Eles não usam blacktie. Uma emoção atual, 20 anos depois. Rio de Janeiro, Jornal do Brasil, 8 set.1981.

- O cinema popular de Leon Hirszman. Rio de Janeiro, Jornal do Brasil, 28 set. 1981.

VENTURA, Zuenir. Viagem ao inconsciente. O mergulho de Leon Hirszman. Rio de Janeiro, Jornal do Brasil, 12 out. 1973. 
ABC DA GREVE - Documentário inédito. Cinemateca Brasileira. SP, 1991.

ALLEN, Robert C. and Gomery, Douglas. Film History: Theory and practice. McGraw Hill, Inc., 1985.

ALMEIDA, Dalmer Pacheco de. Telenovela: o (in)discreto charme da burguesia (desvio de conduta e merchandising de valores) - Dissertação de Mestrado ECO/UFRJ, 1986.

AUMONT, Jacques. A estética do filme. São Paulo, PAPIRUS, 2010.

AUMONT, Jacques. A Imagem. São Paulo, PAPIRUS, 2010.

ALVES, Maria Helena Moreira. Estado e Oposição no Brasil (1964-1984). Petrópolis, Vozes, 1984.

ALMEIDA, Claudio A. O cinema como "agitador de almas": 'Argila', uma cena do Estado Novo. São Paulo, Annablume, 1999.

ANDERSON, Benedict. Nação e Consciência Nacional. São Paulo, Ática, 1989. AUERBACH, Eric. Mimese. São Paulo, Editora Perspectiva, 1971.

ANTUNES, Ricardo. A Rebeldia do Trabalho - O Confronto Operário no ABC Paulista: As Greves de 1978/80. São Paulo, Unicamp, 1988.

BENJAMIN, Walter. A Origem do Drama Barroco. São Paulo, Brasiliense, 1984. BENJAMIN, Walter. Magia e Técnica, arte e política. São Paulo: Brasiliense, 1994.

BERNARDET, Jean Claude. Cinema brasileiro: propostas para uma história. Rio de Janeiro, Paz e Terra, 1979.

Historiografia clássica do cinema brasileiro. Metodologia e pedagogia. São Paulo, Annablume, 1995.

Piranha no mar de rosas. Rio de Janeiro, Paz e Terra, 1982.

Os anos JK : como fala a história ? In: Cineastas e imagens do povo. $2^{\mathrm{a}}$ ed.

São Paulo, Companhia das Letras, 2003, p. 243 - 251.

BERNARDET, Jean-Claude. Historiografia Clássica do Cinema Brasileiro: metodologia e pedagogia. São Paulo, Annablume, 2008.

BERNARDET, Jean-Claude. Cineastas e Imagens do Povo. São Paulo: Brasiliense, 1985.

BERNARDET, Jean-Claude. Brasil em Tempo de Cinema. São Paulo, Cia. das Letras, 2007.

BERNARDET, Jean-Claude. O Nacional e o Popular na Cultura Brasileira (cinema). SP: Brasiliense/ Embrafilme, 1983. 
BETO, Frei. Batismo de Sangue - os Dominicanos e a morte de Carlos Marighella. Rio de Janeiro, Civilização Brasileira, 1985.

BROOKS, Peter. The Melodramatic Imagination. New Haven, Yale University Press, 1995.

CANDIDO, Antonio et al. A personagem de ficção. 6.ed. São Paulo: Perspectiva, 1981.

CANDIDO, Antonio. Literatura e Sociedade. Rio de Janeiro, Ouro sobre Azul, 2011.

CANDIDO, Antonio. Formação da Literatura Brasileira - Momentos Decisivos. Rio de Janeiro, Ouro sobre Azul, 2011.

CAPELATO, Maria Helena e outros (orgs.). História e cinema: dimensões históricas do audiovisual. São Paulo, Alameda Casa Editorial, 2007.

CARONE, Edgar. Movimento Operário no Brasil (1964-1984). São Paulo, DIFEL, 1984.

CARONE, Edgar. O PCB - 1964 a 1982 - vol.3. São Paulo, DIFEL, 1982.

CHARTIER, Roger. O mundo como representação. In: Estudos Avançados. 5 (11): 173 $-191,1991$.

CHAUÍ, Marilena. Conformismo e Resistência. SP: Brasiliense, 1996.

CHAUÍ, Marilena. Cultura e Democracia. SP: Moderna, 1993.

DARIN, Sílvio. Espelho Partido - Tradição e Transformação do Documentário. Rio de Janeiro, Azougue, 2003.

DAVIS, Mike. Planeta Favela. São Paulo, Boitempo, 2006.

DECCA, Edgar de. 1930: O silêncio dos vencidos: memória, história e revolução. São Paulo, Brasiliense, 2004.

FAUSTO, Boris. História do Brasil. SP: Edusp, 2001.

FERNANDES, Florestan, A Ditadura em Questão. SP: T.A.Queiroz, 1982.

FERNANDES, Florestan. Sociedade de Classes e Subdesenvolvimento. São Paulo, Gaudí, 2013.

FERRO, Marc. Cinema e História. RJ: Paz e Terra, 1992.

FIORIN, José Luiz. O Regime de 1964: Discurso e Ideologia. SP: Atual, 1988.

GALVÃO, Maria Rita. Crônica do cinema paulistano. São Paulo, Ática, 1975. . e BERNARDET, Jean Claude. Cinema - Repercussões em caixa de eco ideológica. São Paulo, Brasiliense/Embrafilme, 1983.

GEERTZ, Clifford. A interpretação das culturas. SP: Ômega. 1994.

GINZBURG, Carlo. Representação: a palavra, a idéia, a coisa. In: Olhos de madeira: nove reflexões sobre a distância. São Paulo, Companhia das Letras, 2001, p. 85 - 103. 
GOMES, Paulo Emílio Sales. Trajetória no subdesenvolvimento. SP: Paz e Terra, 1996.

GORENDER, Jacob. Combate nas Trevas - A Esquerda Brasileira: Das Ilusões Perdidas à Luta Armada. São Paulo, Ática, 1987.

HARVEY, David. Para entender o Capital. São Paulo, Boitempo, 2013.

MARTIN, Marcel. A linguagem Cinematográfica. São Paulo, Brasiliense, 2009.

MARX, Karl. O Capital - Livro I. São Paulo, Boitempo, 2013.

MASCARO, Alysson Leandro. Estado e Forma Polítca. São Paulo, Boitempo, 2013.

MORETTIN, Eduardo. O cinema e a Exposição Internacional do Centenário da Independência do Brasil. Artcultura: Revista de História, Cultura e Arte. Uberlândia, Universidade Federal de Uberlândia, Instituto de História, 8 (13): 189 - 201, 2006. Dimensões históricas do documentário brasileiro no período silencioso. In:

Revista Brasileira de História. 25 (49): 125 - 152, jan. - jul. 2005.

Produção e formas de circulação do tema do Descobrimento do Brasil: uma análise de seu percurso e do filme "Descobrimento do Brasil" (1937), de Humberto Mauro. In: Revista Brasileira de História. Dossiê: Brasil, Brasis. 20 (39): 135 - 165, 2000

Quadros em movimento: o uso das fontes iconográficas no filme Os

Bandeirantes (1940), de Humberto Mauro. In: Revista Brasileira de História. Dossiê: Arte e Linguagens. 18 (35):105 - 131, 1998.

A representação da história no cinema brasileiro (1907 - 1949). Anais do

Museu Paulista: História e Cultura Material. São Paulo, Nova Série. 5: 249 - 271, jan./dez. 1997.

NEGRO, Antonio Luigi. Linhas de Montagem - O Industrialismo nacionaldesenvolvimentista e a sindicalização dos trabalhadores. São Paulo, Boitempo, 2004.

ORTIZ, Renato. Cultura Brasileira e Identidade Nacional. SP: Brasiliense, 2003.

PENNA, Lincoln de Abreu. República Brasileira. RJ: Nova Fronteira, 1999.

RAMOS, Alcides Freire. O Canibalismo dos Fracos. Tese de Doutorado. SP: Depto. História/USP, 1996.

RIDENTI, Marcelo e REIS, Daniel Aarão. História do Marxismo no Brasil - Partidos e Movimentos após os anos 1960 - vol.6. São Paulo, Unicamp, 2008.

ROSENFELD, Anatol. O Teatro Épico. SP: Perspectiva, 1994.

SADER, Emir. A Vingança da História. São Paulo, Boitempo, 2007.

SAFATLE, Vladimir e TELES, Edson, Orgs. O que resta da Ditadura - A Exceção Brasileira. São Paulo, Boitempo, 2010.

SCHWARZ, Roberto. Cultura e Política. São Paulo, Paz e Terra, 2005.

SEGALL, Maurício. Controvérsias e Dissonâncias. SP: Edusp/ Boitempo, 2001.

SKIDMORE, Thomas. Brasil: de Getúlio a Castelo. Rio de Janeiro, Paz e Terra, 1996 
SKIDMORE, Thomas. Brasil: de Castelo a Tancredo. Rio de Janeiro, Paz e Terra, 1988.

SZONDI, Peter. Teoria do Drama Moderno (1880-1950). SP: Cosac \& Naify, 2003.

VANOYE, Francis e GOLIOT-LÉTÉ, Anne. Ensaio sobre a análise fílmica. São Paulo, PAPIRUS, 2009.

VESENTINI, Carlos Alberto. A Teia do Fato - Uma Proposta de Estudo sobre a Memória Histórica. São Paulo, Hucitec, 1997.

XAVIER, Ismail. Sertão Mar - Glauber Rocha e a Estética da Fome. São Paulo, Cosac\&Naify, 2007.

XAVIER, Ismail. O Olhar e a Cena. São Paulo, Cosac\&Naify, 2008.

XAVIER, Ismail, Org., A Experiência do Cinema. São Paulo, Graal, 2008.

ZIZEK, Slavoj. Lacrimae Rerum - Ensaios sobre Cinema Moderno. São Paulo, Boitempo, 2009. 